Florida International University FIU Digital Commons

$2-22-2013$

\title{
Does Landscape Context Affect Habitat Value? The Importance of Seascape Ecology in Back-reef Systems
}

Lauren Yeager

Florida International University, lyeag001@fiu.edu

DOI: $10.25148 /$ etd.FI13042307

Follow this and additional works at: https://digitalcommons.fiu.edu/etd

Part of the Biology Commons

\section{Recommended Citation}

Yeager, Lauren, "Does Landscape Context Affect Habitat Value? The Importance of Seascape Ecology in Back-reef Systems" (2013). FIU Electronic Theses and Dissertations. 892.

https://digitalcommons.fiu.edu/etd/892 


\section{FLORIDA INTERNATIONAL UNIVERSITY}

Miami, Florida

\section{DOES LANDSCAPE CONTEXT AFFECT HABITAT VALUE?}

THE IMPORTANCE OF SEASCAPE ECOLOGY IN BACK-REEF SYSTEMS

A dissertation submitted in partial fulfillment of the requirements for the degree of DOCTOR OF PHILOSOPHY

in

BIOLOGY

by

Lauren Ann Yeager 
To: Dean Kenneth G. Furton

College of Arts and Sciences

This dissertation, written by Lauren Ann Yeager, and entitled Does Landscape Context Affect Habitat Value? The Importance of Seascape Ecology in Back-reef Systems, having been approved in respect to style and intellectual content, is referred to you for judgment.

We have read this dissertation and recommend that it be approved.

Maureen A. Donnelly

James W. Fourqurean

Jennifer S. Rehage

Joseph E. Serafy

Craig A. Layman, Major Professor

Date of Defense: February 22, 2013

The dissertation of Lauren Ann Yeager is approved.

Dean Kenneth G. Furton

College of Arts and Sciences

Dean Lakshmi N. Reddi

University Graduate School

Florida International University, 2013 


\section{COPYRIGHT PAGE}

The following chapters have been published in peer-reviewed journals. Copyright release has been obtained from the journals for inclusion in this dissertation.

\section{CHAPTER II}

Yeager, LA, Layman, CA, and Allgeier, JE (2011) Effects of habitat heterogeneity at multiple spatial scales on fish community assembly. Oecologia 167:157-168, doi:10.1007/s00442-011-1959-3

www.springerlink.com/content/8148304464403q13/

\section{CHAPTER III}

Yeager, LA, Acevedo, CL, and Layman, CA (2012) Effects of seascape context on condition, abundance, and secondary production of a coral reef fish, Haemulon plumierii. Marine Ecology Progress Series 462: 231240. doi:10.3354/meps09855

http://www.int-res.com/abstracts/meps/v462/p231-240/

\section{CHAPTER V}

Yeager, LA and Layman, CA (2011) Energy flow to two abundant consumers in a sub-tropical oyster reef food web. Aquatic Ecology 45:267277. doi:10.1007/s10452-01

www.springerlink.com/content/22533581181m7632/ 


\section{ACKNOWLEDGMENTS}

There are many people who contributed to my success during my $\mathrm{Ph} . \mathrm{D}$. that I would like to sincerely thank. First, I would like to thank my family, especially, Mallarie Yeager, Cathleen and James Monroe, Hugh and Marcia Yeager, and Betty Ann Sloss. They have constantly encouraged me to pursue my love of science, from the time I was a little girl to the present. Also, I would like to thank my husband, Lloyd Pierre, who has believed in me and provides unwavering support in my pursuit of my career goals.

I would like to sincerely thank my major professor, Dr. Craig Layman. He went well beyond what was required by an advisor and was always available to me for assistance with every facet of my Ph.D. I would also like to thank my other committee members, Dr. Maureen Donnelly, Dr. James Fourqurean, Dr. Jennifer Rehage, and Dr. Joseph Serafy, for their valuable support during my time at FIU. They each were able to contribute unique viewpoints and advice related to their expertise, improving the quality of my dissertation.

I would to like to thank my labmates, Vanessa Haley-Benjamin, Caroline Hammerschlag-Peyer, Elizabeth Stoner, Zack Jud, Sean Giery, Stephanie Archer, Megan Seese, and Jacob Allgeier who contributed greatly with ideas, fieldwork assistance, and friendship. My other classmates, including Adam Rosenblatt and Katy Cameron, provided valuable advice and assistance. Additionally, I would not have been able to complete my Ph.D. research without a group of amazing FIU undergraduate students who assisted with field and laboratory work, including: Martha Zapata, Christina Acevedo, Joey Peters, Dinorah Chacin, Serian Silliban, Halley Miller, Kevin Bernhart, Greg Mineau, Carlos Villegas, and Patricia Gonzales. 
I received invaluable support from local non-profit groups both in Abaco, Bahamas and in Jupiter, Florida. First, I would like to sincerely thank the staff of Friends of the Environment on Abaco, especially Kristin Williams and Olivia Patternson, for all their support with logistics, outreach and especially their friendship. None of my work that was carried out on Abaco could have been completed with their help. I would also like to thank Darlene Haines, Frank DeRosa and Kaye Rennirt for generously giving me and my assistants lodging in Little Harbour. In Florida, I would like to acknowledge the staff of the Loxahatchee River District, including Albrey Arrington, Bud Howard, Dave Sabin and thank them for their support with logistics, funding, and data. I would especially like to thank Jocelyn O'Neil from the Loxahatchee River Center for her help in coordinating a high school internship program for students from Jupiter High School, and acknowledge Karissa Wasko, Joseph Brooker, Thomas Browning, and Evan McLean for their help with fieldwork.

I would also like to thank my funding sources. I received financial support from a National Science Foundation Graduate Research Fellowship. I was also supported by a Presidential Fellowship and Dissertation Year Fellowship from the University Graduate School at FIU. I received additional support for research and travel expenses from two Sigma-Xi Grants-in-Aid of Research, two Travel Awards from the College of Arts and Sciences at FIU, and two Conference and Professional Development Awards from the Graduate Student Funding Committee at FIU. 


\begin{abstract}
OF THE DISSERTATION
DOES LANDSCAPE CONTEXT AFFECT HABITAT VALUE?

THE IMPORTANCE OF SEASCAPE ECOLOGY IN BACK-REEF SYSTEMS

by
\end{abstract}

Lauren Ann Yeager

Florida International University, 2013

Miami, Florida

Professor Craig A. Layman, Major Professor

Seascape ecology provides a useful framework from which to understand the processes governing spatial variability in ecological patterns. Seascape context, or the composition and pattern of habitat surrounding a focal patch, has the potential to impact resource availability, predator-prey interactions, and connectivity with other habitats. For my dissertation research, I combined a variety of approaches to examine how habitat quality for fishes is influenced by a diverse range of seascape factors in sub-tropical, back-reef ecosystems. In the first part of my dissertation, I examined how seascape context can affect reef fish communities on an experimental array of artificial reefs created in various seascape contexts in Abaco, Bahamas. I found that the amount of seagrass at large spatial scales was an important predictor of community assembly on these reefs. Additionally, seascape context had differing effects on various aspects of habitat quality for the most common reef species, White grunt Haemulon plumierii. The amount of seagrass at large spatial scales had positive effects on fish abundance and secondary production, but not on metrics of condition and growth. The second part of my dissertation focused on how foraging conditions for fish varied across a linear seascape 
gradient in the Loxahatchee River estuary in Florida, USA. Gray snapper, Lutjanus griseus, traded food quality for quantity along this estuarine gradient, maintaining similar growth rates and condition among sites. Additional work focused on identifying major energy flow pathways to two consumers in oyster-reef food webs in the Loxahatchee. Algal and microphytobenthos resource pools supported most of the production to these consumers, and body size for one of the consumers mediated food web linkages with surrounding mangrove habitats. All of these studies examined a different facet of the importance of seascape context in governing ecological processes occurring in focal habitats and underscore the role of connectivity among habitats in back-reef systems. The results suggest that management approaches consider the surrounding seascape when prioritizing areas for conservation or attempting to understand the impacts of seascape change on focal habitat patches. For this reason, spatially-based management approaches are recommended to most effectively manage back-reef systems. 


\section{TABLE OF CONTENTS}

CHAPTER

PAGE

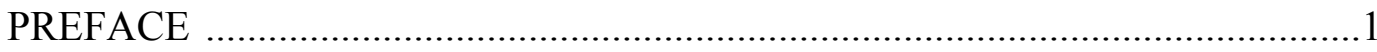

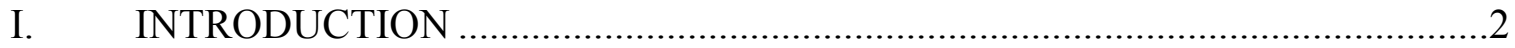

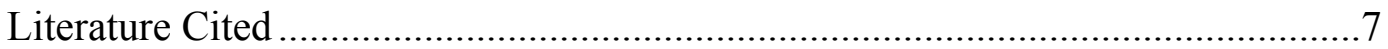

II. EFFECTS OF HABITAT HETEROGENITY AT MULTIPLE SPATIAL SCALES ON FISH COMMUNITY ASSEMBLY ............................................. 11

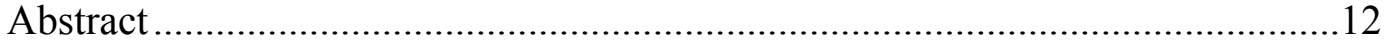

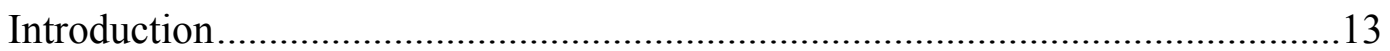

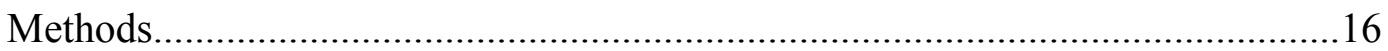

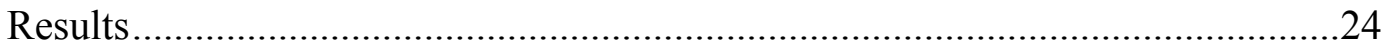

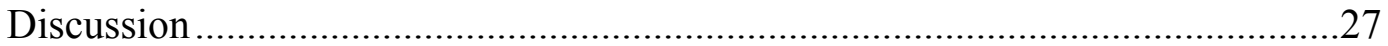

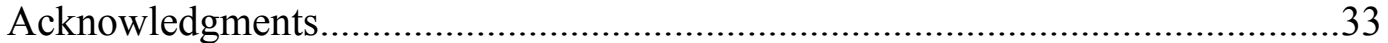

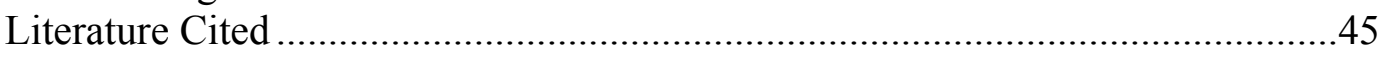

III. EFFECTS OF SEASCAPE CONTEXT ON CONDITION, ABUNDANCE, AND SECONDARY PRODUCTION OF A CORAL REEF FISH, HAMULEON

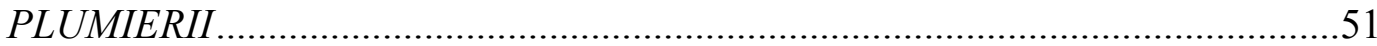

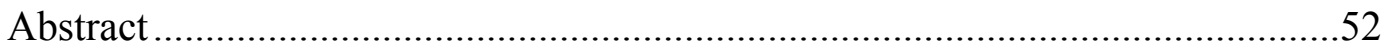

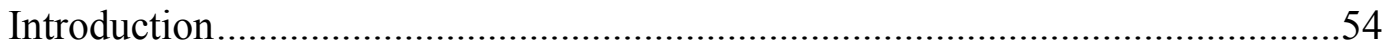

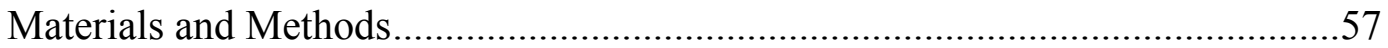

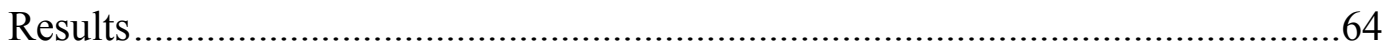

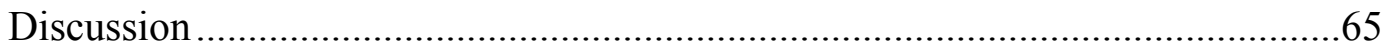

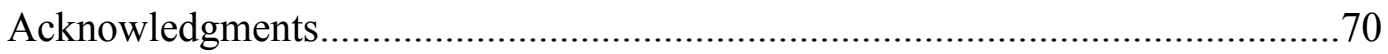

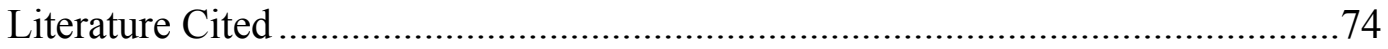

IV. QUANTITY FOR QUALITY: FORAGING TRADE-OFFS FOR A GENERALIST FISH PREDATORS ACROSS AN EVIRONMENTAL

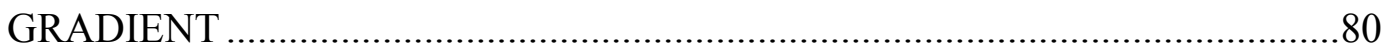

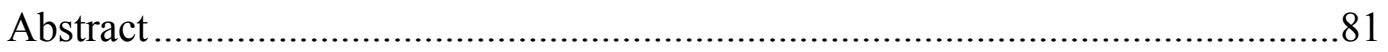

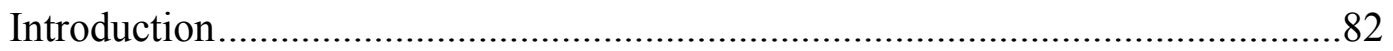

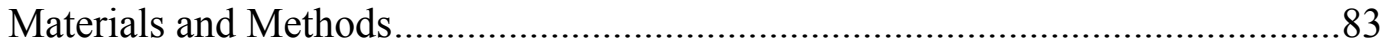

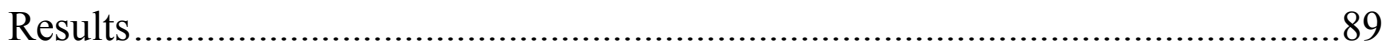

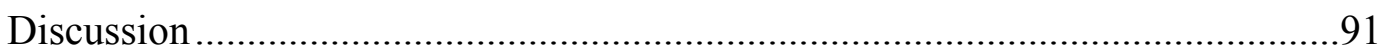

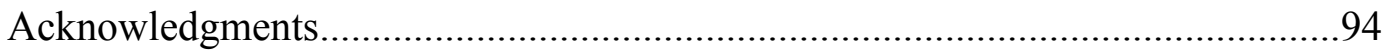

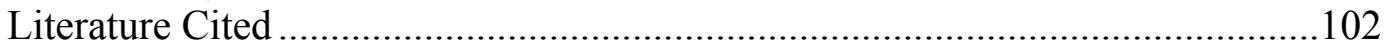

V. ENERGY FLOW TO TWO ABUNDANT CONSUMER IN A SUB-TROPICAL

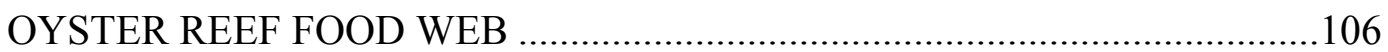

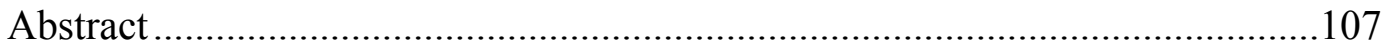

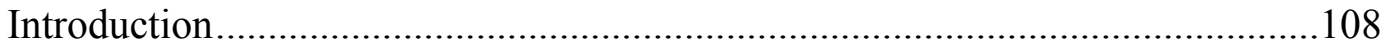




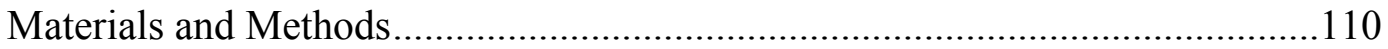

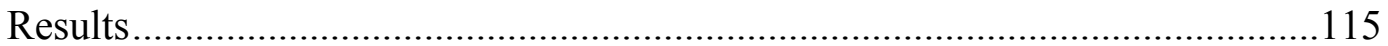

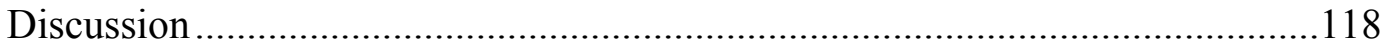

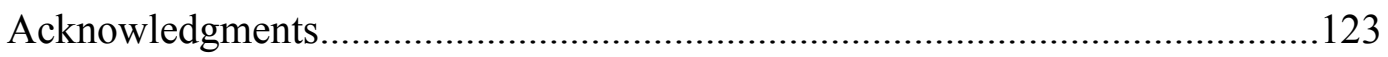

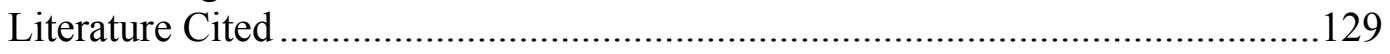

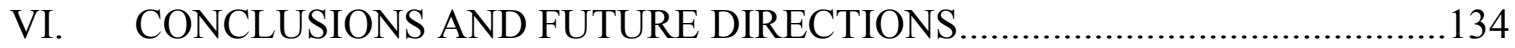

Literature Cited ................................................................................. 140

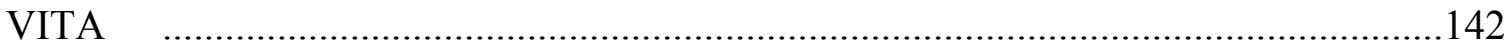




\section{LIST OF TABLES}

TABLE

PAGE

\section{CHAPTER II}

2.1 Description of habitat variables measured with range, mean, and standard deviation among reefs

2.2 Results of BIOENV indicating habitat variables that best explain the differences in community structure among reefs. Day indicates day following reef creation. The best three models for each day are included. $\rho$ represents the Spearman correlation coefficient

2.3 Results of similarity percentages (SIMPER) analysis examining which species contribute most to the Bray-Curtis dissimilarity between reefs with "high" (mean seagrass cover within $100 \mathrm{~m}>20 \%$ ) and "low" (mean seagrass cover within 100 $\mathrm{m}<20 \%$ ) amounts of seagrass within the landscape. Mean abundance \pm standard error (SE) was calculated across all reefs within each group over the last three survey dates (days 152-259).

2.4 Loadings for variables making up principal components from factor analysis of habitat variables relating to each reef. Bold values indicate the strongest explanatory variable(s) for each component.

2.5 Results of General Linear Models of species richness and different abundance measures predicted by principal component groupings of habitat variables. Source $=$ source of variation, $d f=$ degrees of freedom, $\mathrm{MS}=$ mean squares, $\mathrm{F}=\mathrm{F}$ statistic, $P=P$-value based on F-test, $\eta^{2}=$ proportion of variation in dependent variable explained by each predictor, $\mathrm{C}=$ component.

\section{CHAPTER IV}

4.1 Description of five studies sites. Salinity and temperature data courtesy of the Loxahatchee River District from averages over 2008-2009. NA = not available .95

\section{CHAPTER V}

5.1 Isotope values and sample size for oyster reef fauna. Taxa are ordered by increasing $\delta^{15} \mathrm{~N}$ values, with the two focal consumers listed at the bottom. If more than one measurement was made for a given taxon, the mean delta-value (standard deviation) is reported. 


\section{LIST OF FIGURES}

FIGURE

PAGE

\section{CHAPTER II}

2.1 Map of study area showing the locations of artificial reefs within the Bight of Old Robison, Abaco Island, Bahamas.

2.2 Map of study site showing locations and seagrass cover surrounding artificial reefs. Inset picture shows an artificial reef 3 months after construction (June 2009). Each reef is identified by a solid triangle and number. Reefs were located in the Bight of Old Robison, Abaco Island, Bahamas (Fig 2.1)

2.3 Trajectory of (a) species richness, (b) benthic fish abundance (mean \# fish/reef), and (c) the correlation between habitat variables and fish community structure through time. Note y-axis of (b) is plotted on a natural log scale but labels are back-transformed to represent true abundance values

2.4 Non-metric Multidimensional Scaling plot of community structure on reefs through time. Triangles represent an individual survey for each reef $(\mathrm{n}=9$ per day) and are shaded according to survey date

2.5 Partial regression plots derived from General Linear Models showing the relationship between principal component axes of habitat variables (x axes) and (a-c) species richness, (d-f) total fish abundance, (g-i) benthic fish abundance, (j-1) small fish ( $\leq 5 \mathrm{~cm}$ TL) abundance and (m-o) large fish ( $\geq 15 \mathrm{~cm} \mathrm{TL})$ abundance. The habitat variables loading most heavily on each principal component are listed under the x-axes. $P$-values are included for each parameter as well as $\eta^{2}$, i.e., the proportion of total variation explained by each component. Trend lines are shown for significant and marginally significant $(P<0.1)$ relationships

\section{CHAPTER III}

3.1 Map of the study location and artificial reef sites. Panel c.) includes a map of the cover of seagrass within the seascape for each reef. Inset photo shows an artificial reef with a fish assemblage dominated by White grunts

3.2 Density of benthic invertebrates versus the percent cover of seagrass for benthic cores. Note that the density of benthic invertebrates is plotted on a fourth-root scale, but axis labels represent untransformed densities

3.3 Relationship between the mean percent cover of seagrass within the seascape and (a) mean relative condition factor, (b) mean RNA:DNA, (c) abundance, and (d) 
secondary production of White grunts. A trend line is shown for the relationships where $P<0.05$

\section{CHAPTER IV}

4.1 Map of the Loxahatchee River and estuary. Black dots indicate locations of the five study sites.

4.2 Aspects of snapper diet along an estuarine gradient: (a) percent of snapper with food in their stomachs, (b) mean ( \pm standard error) gut fullness, and (c) mean ( \pm standard error) $\delta^{13} \mathrm{C}$ of Gray snapper fin tissue from 5 sites along the gradient. Gray bars to the right of plot represent range of $\delta^{13} \mathrm{C}$ values from marine or mangrove/intertidal carbon source pools in the estuary

4.3 Composition of Gray snapper diets by volume based on (a) major taxonomic groupings of prey, (b) habitat source of prey items, and (c) quality of prey from 5 study sites. I present only data based on volume for simplicity, as patterns for diets based on number were generally similar

4.4 Mean ( \pm standard error) energy density of snapper prey items in kcal/g DW. Similar letters denote groups that do not differ statistically at $\alpha=0.05$.

4.5 Linear growth curves based on log (age) versus log (length) for snapper from 5 sites along the environmental gradient 100

4.6 Box plots of \% lipid in muscle based on dry weight for Gray snapper from 5 sites along an environmental gradient.

\section{CHAPTER V}

5.1 Map of the Northwest Fork of the Loxahatchee River. Areas in black represent oyster reefs

5.2 Composition diet (by volume) of two size classes of Gray snapper (Lutjanus griseus) and Crested goby (Lophogobius cyprinoides) based on prey items (a) and habitat source of prey (b). Primary producer prey category includes vascular plants, plant detritus and algae.

5.3 Model food web highlighting trophic pathways leading to Gray snapper (Lutjanus griseus) (a) and Crested goby (Lophogobius cyprinoides) (b). Black dots indicate mean isotopic value for each species. Bars around Gray snapper and Crested goby dots represent standard deviation. Error bars were omitted from other species for simplicity but are given in Table 1. Arrows indicate a direct trophic link as 
determined by stomach content analysis. The width of arrows leading to a consumer reflects the proportion (by volume) of that prey item in snapper diets. The $\delta^{13} \mathrm{C}$ ranges of primary producers are represented by gray bars below the $\mathrm{x}-$

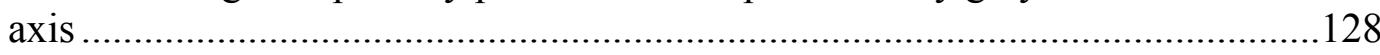




\section{PREFACE}

Chapters II, III and V have been published as detailed on the Copyright Page.

The following chapter is currently in review with a peer-reviewed journal:

\section{CHAPTER IV}

Yeager, LA, Hammerschlag-Peyer, CM, and Layman, CA. In review. Quantity for quality: foraging trade-offs for a generalist fish predator across an environmental gradient. Canadian Journal of Fisheries and Aquatic Sciences. 
CHAPTER I

INTRODUCTION 
The role of surrounding landscapes in affecting community structure and ecosystem processes is a core area of study in ecology (Wu \& Hobbs 2002; Turner 2005a). Spatial heterogeneity, once ignored by ecologists to simplify models or theory, is now recognized as a central driver for many ecological processes (Pickett \& Cadenasso 1995). Landscape ecology is often defined as the study of how habitat identity and spatial configurations affect particular aspects of ecosystem function (Turner 1989). A landscape approach is commonly used to assess human impacts on ecosystem function, and is beneficial in developing effective conservation strategies (Andren 1994).

Organisms exist in highly heterogeneous environments and landscape ecology is a useful approach to understand spatial patterns of abundance (Wiens 1976). A recent review by (Mazerolle \& Villard 1999) found that patch and landscape characteristics were important variables explaining the distributions of a wide array of vertebrate taxa. Surrounding habitats may control species distributions by affecting resource availability, dispersal success and predator-prey dynamics (Polis et al. 1997; Turner 2005b). The spatial scale at which organisms respond to the surrounding habitat varies depending on individual life history strategies or body size (Vos et al. 2001; Goodwin \& Fahrig 2002; Grober-Dunsmore et al. 2008); there is no single scale of variation which is relevant for a particular species or characteristic of interest.

While the importance of landscape context has been well accepted in terrestrial environments, little is known about the role of landscape (or seascape) context and its effect on communities in the marine realm. Many marine species move among different habitat patches or types over short (daily) and long (annual) temporal scales (Burke 1995; Cocheret de la Moriniere et al. 2002; Pittman \& McAlpine 2003; Faunce \& Serafy 2007; 
Verweij et al. 2007). Much research focuses on simply identifying a limited set of habitat types that is most important for individuals, populations or species (Beck et al. 2001; Dahlgren \& Marr 2004). Yet, habitat types exist in complex mosaics. For example, in tropical marine systems, mangroves, seagrass and coral reef habitats are often intermixed in the nearshore environment (Parrish 1989; Dahlgren \& Marr 2004). Therefore, application of landscape ecology to the marine realm has value to better understand ecological patterns in these systems (Robbins and Bell 1994). The surrounding seascape has been shown to affect important ecological functions for macroinvertebrates and fishes in temperate environments (Irlandi et al. 1995; Irlandi \& Crawford 1997; Hovel \& Fonseca 2005), and initial studies suggest that the surrounding seascape may also partially determine relative fish densities among habitat types in tropical systems (e.g., Turner et al. 1999; Kendall et al. 2003; Pittman et al. 2004; Pittman et al. 2007b; Drew \& Eggleston 2008; Grober-Dunsmore et al. 2008; Gullstrom et al. 2008).

The "back-reef" comprises all of those environments on the leeward side of the coral reef crest, including mangroves, seagrasses, and patch reefs (Adams et al. 2006). In back-reef systems, there appears to be wide variation in value of a given habitat type among locations. For example, it is likely that not all mangrove habitats function equally in their support of juvenile reef fishes (Blaber 2007). In particular, the surrounding seascape has the potential to change the value of a habitat to organisms, and may influence the recruitment success and assemblage structure of fishes associated with mangroves (e.g., Drew and Eggleston 2008, Pittman et al. 2007). Similarly, the seascape context of coral reefs in the U.S. Virgin Islands was found to be an important variable 
explaining fish community structure (Grober-Dunsmore et al. 2008). Gullstrom et al. (2008) found that distance to structured habitats like mangroves and coral reefs explained some of the variation in seagrass fish communities. Connectivity with other habitats, physiochemical variables, and larval supply, all may influence the habitat value of backreef environments (Faunce \& Layman 2009).

To date, most work attempting to link seascape context to ecological patterns in back-reef systems have relied on correlative approaches (Grober-Dunsmore et al. 2009). These approaches are useful in developing hypotheses about the effects of seascape pattern on the structure and function of back-reef fish communities. To truly link pattern and process and isolate the effects of seascape context, manipulative approaches are needed. Additionally, most studies examining the importance of seascape context of back-reef fishes have focused on structural responses (changes in species richness or abundance) (Pittman et al. 2007b; Pittman et al. 2007c; Drew \& Eggleston 2008; GroberDunsmore et al. 2008; Gullstrom et al. 2008). To further improve understanding the impacts of seascape context on habitat quality for fishes, more work on understanding ecological processes and functions affected by seascape context is necessary. For my dissertation work, I have focused on addressing two knowledge gaps by using experimental approaches and moving beyond simple structural responses in fish communities to varying seascape context.

For my dissertation research, I combined a variety of approaches to examine how habitat quality for fishes is influenced by a diverse range of seascape factors in back-reef tropical ecosystems. Each of my chapters contributes to this goal in a different way. Two of my chapters that consider empirical data were conducted in 
seagrass/patch reef systems of The Bahamas and the other were conducted in an estuarine system in Florida. Chapters II and III built upon classic landscape ecology approaches to link seascape factors to aspects of population, community and ecosystem ecology of reef fishes. In Chapter II, I examined the "Effects of habitat heterogeneity at multiple spatial scales on fish community assembly." The study was unique because it was among the first to use a manipulative approach to link seascape context to community assembly of fishes on simulated patch reefs. Chapter III built on this work and focused on the "Effects of seascape context on condition, abundance, and secondary production of a coral reef fish, Haemulon plumierii." Grunts (Haemulidae) were found to respond strongly to seascape context in the previous study, and by focusing on one species (White grunt, $H$. plumierii), I was able to gain a more detailed understanding of how seascape context can affect various aspects of habitat quality for this fish species.

The next two chapters address studies that were conducted across a linear seascape (estuarine) gradient and focused on how trophic ecology can help elucidate habitat linkages and mechanisms allowing organisms to remain successful in terms of foraging and growth across different seascapes. Specifically, Chapter IV examines "Quantity for quality: foraging trade-offs for a generalist fish predator across an environmental gradient." The study identified foraging trade-offs that allowed Gray Snapper (Lutjanus griseus) to maintain equal levels of condition and growth among mangrove habitats in different seascape settings. Chapter V, entitled "Energy flow to two abundant consumers in a sub-tropical oyster reeffood web," compares food web linkages to Gray Snapper and Crested Goby (Lophogobius cyprinoides) and highlights the importance of species identity and body size in controlling trophic-based habitat linkages 
among oyster reef and mangrove habitats. All four data chapters evaluate the importance of seascape context in unique ways by using different approaches and metrics to evaluate habitat quality.

The seascape approach to the study of back-reef ecosystems may be critical for proper management of reef fishes. Creation of marine protected areas is an important tool for management of fisheries and habitat conservation. Protected areas should include those habitats critical to the support of all life stages of focal species. Because of limited funds and resources, it is important that we prioritize conservation efforts. Furthermore, coastal zones are becoming increasingly developed resulting in changing seascapes (Millennium Ecosystem Assessment, 2005). Understanding how changing seascape context affects target populations as well as how organisms may be able to adapt to changing environments is critical to be able to predict the impacts of human development. By combining a variety of approaches, I gained a more complete and detailed understanding of how seascape context affects the ecology of nearshore fishes. The results of my dissertation will contribute to our understanding of basic ecology of back-reef fishes as well as how to best manage and conserve habitats essential to critical life stages.

\section{Literature Cited:}

Andren H. (1994). Effects of Habitat Fragmentation on Birds and Mammals in Landscapes with Different Proportions of Suitable Habitat - a Review. Oikos, 71, 355-366.

Beck M., Heck Jr. K., Able K., Childers D., Eggleston D., Gillanders B., Halpern B.H., CG, Hoshino K., Minello T., Orth R., Sheridan P. \& Weinstein M. (2001). The 
identification, conservation, and management of estuarine and marine nurseries for fish and invertebrates. Bioscience, 51, 633-641.

Burke N.C. (1995). Nocturnal Foraging Habitats of French and Bluestriped Grunts, Haemulon flavolineatum and H. sciurus, at Tobacco Caye, Belize. Environ. Biol. Fishes, 42, 365-374.

Cocheret de la Moriniere E., Pollux B.J.A., Nagelkerken I. \& van der Velde G. (2002). Post-settlement life cycle migration patterns and habitat preference of coral reef fish that use seagrass and mangrove habitats as nurseries. Estuar. Coast. Shelf Sci., 55, 309-321.

Dahlgren C. \& Marr J. (2004). Back reef systems: Important but overlooked components of tropical marine ecosystems. Bull. Mar. Sci., 75, 145-152.

Drew C.A. \& Eggleston D.B. (2008). Juvenile fish densities in Florida Keys mangroves correlate with landscape characteristics. Mar. Ecol. Prog. Ser., 362, 233-243.

Faunce C.H. \& Layman C.A. (2009). Sources of variation that affect perceived nursery function in mangroves. In: Ecological Linkages across Tropical Coastal Ecosystems (ed. Nagelkerken I). Springer New York, USA, pp. 401-421.

Faunce C.H. \& Serafy J.E. (2007). Nearshore habitat use by gray snapper (Lutjanus griseus) and bluestriped grunt (Haemulon sciurus): environmental gradients and ontogenetic shifts. Bull. Mar. Sci., 80, 473-495.

Goodwin B.J. \& Fahrig L. (2002). Effect of landscape structure on the movement behaviour of a specialized goldenrod beetle, Trirhabda borealis. Canadian Journal of Zoology-Revue Canadienne De Zoologie, 80, 24-35.

Grober-Dunsmore R., Frazer T.K., Beets J.P., Lindberg W.J., Zwick P. \& Funicelli N.A. (2008). Influence of landscape structure on reef fish assemblages. Landsc. Ecol., $23,37-53$.

Grober-Dunsmore R., Pittman S.J., Caldow C., Kendall M.S. \& Frazer T.K. (2009). A landscape ecology approach for the study of ecological connectivity across tropical marine seascapes. In: Ecological Connectivity among Tropical Coastal Ecosystems (ed. Nagelkerken I). Springer, pp. 493-530.

Gullstrom M., Bodin M., Nilsson P.G. \& Ohman M.C. (2008). Seagrass structural complexity and landscape configuration as determinants of tropical fish assemblage composition. Mar. Ecol. Prog. Ser., 363, 241-255.

Hovel K.A. \& Fonseca M.S. (2005). Influence of seagrass landscape structure on the juvenile blue crab habitat-survival function. Mar. Ecol. Prog. Ser., 300, 179-191. 
Irlandi E.A., Ambrose W.G. \& Orlando B.A. (1995). Landscape Ecology and the MarineEnvironment - How Spatial Configuration of Seagrass Habitat Influences Growth and Survival of the Bay Scallop. Oikos, 72, 307-313.

Irlandi E.A. \& Crawford M.K. (1997). Habitat linkages: The effect of intertidal saltmarshes and adjacent subtidal habitats on abundance, movement, and growth of an estuarine fish. Oecologia, 110, 222-230.

Kendall M.S., Christensen J.D. \& Hillis-Starr Z. (2003). Multi-scale data used to analyze the spatial distribution of French grunts, Haemulon flavolineatum, relative to hard and soft bottom in a benthic landscape. Environ. Biol. Fishes, 66, 19-26.

Mazerolle M.J. \& Villard M.A. (1999). Patch characteristics and landscape context as predictors of species presence and abundance: A review. Ecoscience, 6, 117-124.

Millennium Ecosystem Assessment (2005). Ecosystems and Human Well-being: Wetlands and Water Synthesis. World Resource Institute, Washington, DC.

Parrish J.D. (1989). Fish Communities of Interacting Shallow-Water Habitats in Tropical Oceanic Regions. Mar. Ecol. Prog. Ser., 58, 143-160.

Pickett S.T.A. \& Cadenasso M.L. (1995). Landscape Ecology - Spatial Heterogeneity in Ecological-Systems. Science, 269, 331-334.

Pittman S.J., Caldow C., Hile S.D. \& Monaco M.E. (2007a). Using seascape types to explain the spatial patterns of fish in the mangroves of SW Puerto Rico. Mar. Ecol. Prog. Ser., 348, 273-284.

Pittman S.J., Christensen J.D., Caldow C., Menza C. \& Monaco M.E. (2007b). Predictive mapping of fish species richness across shallow-water seascapes in the Caribbean. Ecol. Model., 204, 9-21.

Pittman S.J. \& McAlpine C.A. (2003). Movements of marine fish and decapod crustaceans: Process, theory and application. Advances in Marine Biology, Vol 44, 44, 205-294.

Pittman S.J., McAlpine C.A. \& Pittman K.M. (2004). Linking fish and prawns to their environment: a hierarchical landscape approach. Mar. Ecol. Prog. Ser., 283, 233254.

Polis G.A., Anderson W.B. \& Holt R.D. (1997). Toward an integration of landscape and food web ecology: The dynamics of spatially subsidized food webs. Annu. Rev. Ecol. Syst., 28, 289-316.

Turner M.G. (1989). Landscape Ecology - the Effect of Pattern on Process. Annu. Rev. Ecol. Syst., 20, 171-197. 
Turner M.G. (2005a). Landscape ecology in North America: Past, present, and future. Ecology, 86, 1967-1974.

Turner M.G. (2005b). Landscape ecology: What is the state of the science? Annu. Rev. Ecol. Evol. Syst., 36, 319-344.

Turner S.J., Hewitt J.E., Wilkinson M.R., Morrisey D.J., Thrush S.F., Cummings V.J. \& Funnell G. (1999). Seagrass patches and landscapes: The influence of wind-wave dynamics and hierarchical arrangements of spatial structure on macrofaunal seagrass communities. Estuaries, 22, 1016-1032.

Verweij M.C., Nagelkerken I., Hol K.E.M., van den Beld A.H.J.B. \& van der Velde G. (2007). Space use of Lutjanus apodus including movement between a putative nursery and a coral reef. Bull. Mar. Sci., 81, 127-138.

Vos C.C., Verboom J., Opdam P.F.M. \& Ter Braak C.J.F. (2001). Toward ecologically scaled landscape indices. Am. Nat., 157, 24-41.

Wiens J.A. (1976). Population responses to patchy environments. Annu. Rev. Ecol. Syst., 7, 81-120.

Wu J.G. \& Hobbs R. (2002). Key issues and research priorities in landscape ecology: An idiosyncratic synthesis. Landsc. Ecol., 17, 355-365. 
CHAPTER II

EFFECTS OF HABITAT HETEROGENEITY AT MULTIPLE SPATIAL SCALES ON FISH COMMUNITY ASSEMBLY 


\begin{abstract}
Habitat variability at multiple spatial scales may affect community structure within a given habitat patch, even within seemingly homogenous landscapes. In this context, I tested the importance of habitat variables at two spatial scales (patch and landscape) in driving fish community assembly using experimental artificial reefs constructed across a gradient of seagrass cover in a coastal bay of The Bahamas. I found that species richness and benthic fish abundance increased over time, but eventually reached an asymptote. The correlation between habitat variables and community structure strengthened over time, suggesting deterministic processes were detectable in community assembly. Abundance of benthic fishes, as well as overall community structure, were predicted by both patch- and landscape-scale variables, with the cover of seagrass at the landscape-scale emerging as the most important explanatory variable. Results of this study indicate that landscape features can drive differences in community assembly even within a general habitat type (i.e., within seagrass beds). A primary implication of this finding is that, human activities driving changes in seagrass cover may cause significant shifts in faunal community structure well before complete losses of seagrass habitat.
\end{abstract}

Key words artificial reef $\cdot$ assembly rules $\cdot$ landscape ecology $\cdot$ habitat patch $\cdot$ seagrass 


\section{Introduction}

The importance of scale is a core tenet of the ecological sciences (Levin 1992; Schneider 2001). Spatial heterogeneity, once ignored by ecologists in order to simplify models or theory, is now recognized as a central driver to many ecological processes (Pickett \& Cadenasso 1995). In this context, landscape ecology is often defined as the study of how habitat identity and habitat configurations at larger spatial scales affect particular aspects of community structure and ecosystem function (Turner 1989). The degree of heterogeneity in environmental variables and resource distribution varies depending on the particular scale of study, necessitating a multi-scale approach to describe organismenvironment interactions (Sandel \& Smith 2009).

Causal mechanisms explaining patterns of organism abundance become increasingly difficult to identify with increasing scale of study (Wu \& Hobbs 2002; Ims 2005). The notable lack of mechanistic-driven experiments at a landscape-scale is primarily the result of feasibility (Ims 2005), as the broad spatial scales at which many landscape processes occur make manipulation and replication difficult. However, such experimental manipulations of landscapes are needed to mechanistically link ecological processes to landscape structure, as correlative relationships may not provide sufficient background to build appropriate predictive models. For example, experimental manipulation of habitat fragmentation in terrestrial systems have failed to consistently support predicted relationships between patch size and species richness from observational studies (Debinski \& Holt 2000).

While landscape ecology started out as primarily a terrestrial discipline, it is increasingly applied to explore organism-habitat relationships in aquatic environments 
(Robbins \& Bell 1994; Grober-Dunsmore et al. 2009). For example, the surrounding landscape, or landscape context, has been shown to affect important ecological factors (e.g., growth or predation risk) for macroinvertebrates and fishes in temperate seagrass beds and oyster reefs (Irlandi et al. 1995; Irlandi \& Crawford 1997; Grabowski et al. 2005; Hovel \& Fonseca 2005). Even variations within habitat types (e.g., patchiness of seagrass cover at large spatial scales) have been correlated with predation risk and foraging efficiency of predators (Irlandi 1994; Irlandi et al. 1995). Initial studies applying landscape approaches to tropical marine systems indicate that landscape structure (cover and pattern of surrounding habitat types) likely play an important role in determining fish community composition, abundance and species richness (Pittman et al. 2004; Pittman et al. 2007b; Grober-Dunsmore et al. 2008). While such correlative evidence is accumulating, a mechanistic understanding of such processes is fundamentally lacking.

Many nearshore systems are considered to be structure-limited (Hixon \& Beets 1989), and thus structurally complex habitats (e.g., patch reefs) are critical habitat for many ecologically and economically important species (Nagelkerken et al. 2000b). Further, because many of the species that use structurally complex habitats during the day are known to migrate to adjacent areas at night to feed (Ogden \& Ehrlich 1977; Nagelkerken et al. 2000a; Luo et al. 2009), characteristics of preferred foraging grounds (e.g., distance to feeding area, cover of soft-bottom habitats) may be correlated with faunal abundance (Kendall et al. 2003; Pittman et al. 2007b). In such cases, it is expected that landscape context would be particularly important in structuring communities.

The objective of the current study was to determine how habitat variables at two spatial scales (which I term patch- and landscape-scale) affect fish community assembly 
in sub-tropical nearshore systems. By creating new structure (i.e., artificial reefs), I could model natural patch reef community assembly and control for variation inherent in observational studies of patch reef communities. I was also able to manipulate the habitat context of artificial reefs by creating reefs across a gradient of seagrass cover to explore the link between landscape structure and fish colonization. I tested if fish community assembly followed expected patterns of community stabilization through time, and if variation in landscape structure within a single matrix habitat (within seagrass beds) affects fish community structure independent of reef characteristics. Specifically, I tested the following hypotheses:

$\mathbf{H}_{1}$ : Overall, species richness and fish abundance will increase over time, eventually reaching an asymptote.

$\mathbf{H}_{2}$ : a) The composition of the fish community will change over time and b) variation in environmental variables will better predict differences in community structure among reefs as time increases, as deterministic processes become more important at higher fish densities.

$\mathbf{H}_{3}$ : Following community stabilization, landscape context will affect the diversity, abundance, and community structure of fishes on artificial reefs. Specifically, the cover of seagrass at a large spatial scale will positively affect species richness and fish abundance, and body size of fishes will determine the spatial scale at which they respond to their landscape, i.e., small fish abundance will be more closely related to patch-scale 
habitat variables and larger fish, i.e., piscivore, abundance will be more closely related to landscape-scale variables.

\section{Methods}

Data Collection

The study was conducted in The Bight of Old Robinson, Abaco, Bahamas (Fig. 2.1). The Bight of Old Robinson is a semi-enclosed bay with a mosaic of seagrass, sand, and hardbottom habitats. Artificial reefs were constructed in sand and seagrass habitat in the Bight. Artificial reefs support similar communities to natural patch reefs (Alevizon et al. 1985), and have been used extensively as experimental units for studies of patch reef communities (Shulman 1985; Hixon \& Beets 1989; Miller 2002). Artificial reefs were constructed of 40 cinder blocks ( $\sim 41 \mathrm{~cm} \times 20 \mathrm{~cm} \times 20 \mathrm{~cm}$ ) in a pyramid shape (Fig. 2.2). Nine reefs were constructed along a gradient of seagrass cover in March 2009. Reefs were placed at least $125 \mathrm{~m}$ apart to minimize among-reef movements of transient fish species. Previous artificial reef studies support this assumption, e.g., similar artificial reefs placed $50 \mathrm{~m}$ apart have been treated as spatially independent in analyses (Hixon \& Beets 1989). Additionally, site fidelity by fishes on my artificial reefs was supported with preliminary results of a tagging study on one of the dominant fish species, White grunt (Haemulon plumierii), where $100 \%$ of fish that were re-captured 6 months after tagging $(n=6)$ were on their original reef of capture (LA Yeager, unpublished data). I confirmed that there was no relationship between the locations of the reefs (defined by x,y 
coordinates) and their landscape composition (i.e., measures of patch- and landscapescale habitat variables, see below) with linear regression. This result further supports the assumption that the spatial arrangement of the reefs did not affect landscape context or community assembly.

Underwater visual census was employed throughout the study period to estimate fish abundance and recruitment (Layman et al. 2004). All fishes within $4 \mathrm{~m}$ of each reef were surveyed until the observer was confident all fishes had been recorded. Fish communities were surveyed on 12 dates $(1,7,20,27,34,51,70,96,126,152,212,259$ days after reef construction). All fishes enumerated were identified to the lowest possible taxonomic level and size (total length) of each individual was estimated to the nearest $\mathrm{cm}$. Surveys were completed by a snorkeler (LAY or CAL) trained in fish identification and underwater fish size estimation.

Habitat variables were measured for each reef and were then grouped at patch and landscape spatial scales (the term "habitat variables" will be used to describe variables measured at either spatial scale, Table 2.1). Patch-scale was used to describe habitat variables measured in close proximity to the reef (extent of measurement $=4 \mathrm{~m})$. Previous studies have reported $100 \mathrm{~m}$ to be the scale at which the most abundant species in this study respond to their environment (Kendall et al. 2003; Pittman et al. 2007b), and therefore this was chosen as the focal landscape extent. Exploratory data analysis using landscape areas with smaller radii (e.g., $50 \mathrm{~m}$ ) gave similar results, but with poorer model fit, so $100 \mathrm{~m}$ was retained as the focal landscape extent.

Patch-scale variables included depth, mean seagrass shoot density within $4 \mathrm{~m}$ of the reef and mean seagrass shoot height within $4 \mathrm{~m}$ of the reef. Tide-corrected depth to 
the base of each reef was measured to the nearest $0.1 \mathrm{~m}$. In order to quantify the amount of seagrass (Thalassia testudinum) around each reef, $18-0.01 \mathrm{~m}^{2}$ quadrats were placed haphazardly between $2 \mathrm{~m}$ and $4 \mathrm{~m}$ from the base of the reef. Within each quadrat, all seagrass blades were counted and the heights of five haphazardly selected blades were measured to the nearest $\mathrm{cm}$. Shoot densities and shoot heights measured in each quadrat were averaged among all 18 quadrats to estimate patch-scale values for each reef. Seagrass shoot density and shoot height within $4 \mathrm{~m}$ of the reef were used to assess finescale differences in seagrass bed characteristics, as these metrics (as opposed to seagrass percent cover at a scale of 100 s of meters) accurately capture seagrass heterogeneity over small spatial scales (Fonseca et al. 2002). While other seagrasses or macroalgae may affect the function and fauna associated with seagrass beds within the study area (Seese et al., unpublished data), seagrass beds surrounding the reefs were dominated by $T$. testudinum and, therefore, I focused only on this species.

Landscape-scale variables included distance to open ocean, distance to structure, mean seagrass cover within $100 \mathrm{~m}$ of the reef, habitat diversity within $100 \mathrm{~m}$ of the reef and habitat contrast within 100 m of the reef. Distance to open ocean (mouth of the Bight) was included as a proxy for the larval recruitment source. Alternatively, distance to the nearest structure (natural patch reefs or large artificial structure such as sunken boats) could affect the recruitment rate of sub-adult and adult individuals to reefs. Distance to open ocean and distance to structure were estimated using Google Earth ${ }^{\circledR}$ (Google 2010). To assess seagrass densities at larger spatial scales, estimates of percent cover were used. One- $\mathrm{m}^{2}$ quadrats were placed at 609 haphazard points throughout the study area and the percent cover of seagrass was estimated using the modified Braun- 
Blanquet method (Fourqurean et al. 2001). The distribution of seagrass in the study area was mapped by using the measured percent cover of seagrass at these fixed points and interpolating these coverages to a $31,000 \mathrm{~m}^{2}$ area (circle with $100 \mathrm{~m}$ radius) around each reef with an Inverse Distance Weighted Interpolation (Lirman \& Cropper 2003). Seagrass cover mapped within $100 \mathrm{~m}$ of each reef (Fig. 2.2) revealed a gradient in percent cover of seagrass and patchiness. While there may be some seasonality in the cover of seagrass (Fourqurean et al. 2001), seagrass was mapped near the end of the growing season when seagrass cover would be at its maximum (August 2009). The map of seagrass cover around each reef was used to calculate the remaining landscape-scale variables described below.

The mean percent cover of seagrass was estimated within $100 \mathrm{~m}$ of each reef using ArcGIS v 9 (ERSI 2008). Patches of varying seagrass cover were defined by grouping seagrass cover in 5 categories $(0-10.0 \%, 10.1-25.0 \%, 25.1-50.0 \%, 50.1-75.0 \%$, and 75.1-100\%). Habitat diversity around each reef was calculated by the same method as Shannon-Weiner diversity (Pielou 1966) indices for community data, but with the area of patches used instead of species abundance. Habitat diversity within $100 \mathrm{~m}$ for each reef was calculated in Fragstats 3.3 (McGarigal et al. 2002). Habitat contrast (a measure of patchiness) was also computed in Fragstats 3.3 by calculating the "difference" in the value of seagrass cover between each $1 \mathrm{~m}^{2}$ cell and those bordering it, where differences were weighed by the change in percent cover (e.g., a cell with 50.1-75.0\% cover was weighted as 0.25 different from one of $75.1-100 \%$ cover). When adjacent cells vary greatly in percent cover of seagrass, the contrast index is higher and the landscape is considered to be patchier. 


\section{Data Analysis}

All fish taxa were assigned to a functional group based on trophic guild (herbivorous, omnivorous, invertivorous, piscivorous) and foraging habitat (benthic, pelagic) following previously reported dietary information based on stomach contents (Randall 1967; Layman \& Silliman 2002; Cocheret de la Moriniere et al. 2003) and observations from my study system. Forty-five taxa observed on the reefs were classified as benthic feeders. These species (referred to as "benthic") may be most likely to respond to habitat variables because they utilize resources that were dependent on the benthic habitat type. As such, some analyses only focused on this particular functional grouping. Other analyses required consideration of the entire fish community (e.g., diversity metrics) and included 14 additional taxa that were more transient and are expected to be primarily pelagic feeders (e.g., tomtates, Haemulon aurolineatum, and jacks, Carangidae). These transient taxa often comprised large schools that may have been loosely associated with reefs during a survey event.

Patterns in species richness and benthic fish abundance were evaluated over time $\left(\mathrm{H}_{1}\right)$. Benthic fish abundance was $\ln$ transformed in order to homogenize variance among reefs over time. Next, the mean of species richness and $\ln$ (benthic fish abundance) for each survey date was calculated across all reefs. In order to evaluate the overall trajectory of species richness and fish abundance over time, the relationships between time and both mean species richness and mean $\ln ($ benthic fish abundance) were modeled with various linear, polynomial and asymptotic models selected after visual inspection of the data. Specifically, I fit linear, second order polynomials, inverse first and second order 
polynomials, exponential rise to maximum models with 2 and 3 parameters, and $2^{\text {nd }}$ order power functions. I evaluated candidate models using adjusted $r^{2}$ values, where the coefficient of determination $\left(r^{2}\right)$ is adjusted for the number of parameters in the model. The adjusted $r^{2}$ value is useful in determining if adding new parameters into the model increases overall model fit (Draper \& Smith 1998). For this reason, I used the adjusted $r^{2}$ to select the most appropriate and parsimonious model that best modeled trends in each of species richness and fish abundance over time. Data met the assumption of normality in both cases $(P=0.69$ and $P=0.61$, respectively $)$.

Next, analyses of community structure were performed for all benthic species and evaluated over time. Community data were analyzed using species-by-sample matrices that were square-root transformed to down-weight the influence of dominant taxa (Clarke 1993). The similarity between community structure over time and among reefs was evaluated graphically using non-metric Multidimensional Scaling (nMDS), where communities that are more similar are closer together in space (PRIMERC v 6 , Clarke 1993, (Clarke \& Gorley 2006). This nMDS was used to visualize the clustering among surveys through time $\left(\mathrm{H}_{2} \mathrm{a}\right)$.

Additionally, the strength of the correlation between benthic fish community structure and habitat variables was evaluated over time $\left(\mathrm{H}_{2} \mathrm{~b}\right)$. First a BIOENV algorithm was employed, which predicts which habitat variables best explain differences in community structure and reports the correlation between habitat variables and fish community structure in PRIMER@ v 6 (Clarke 1993). The BIOENV algorithm maximizes the rank correlation between the Bray-Curtis similarity matrix of square-root transformed abundance data for each taxa and a resemblance matrix of normalized habitat 
data to select the habitat variables that explain most of the variation in community structure. Similar to the treatment of species richness and abundance data, linear, polynomial and asymptotic regression models were used to test the relationship between time and the variation in fish community structure explained by habitat variables (correlation output from the BIOENV). Data met the assumption of normality $(P=0.93)$. I selected the last three survey dates (days 152, 212, and 259) for the remaining analyses investigating which habitat variables were most important in driving differences in community structure, fish abundance and species richness among reefs $\left(\mathrm{H}_{3}\right)$. I selected these dates, as species richness, fish abundance, and community structure remained relatively constant following this time period, and thus I considered the community to be relatively stable. First, I treated communities surveyed on each date separately and used the results of the BIOENV algorithm described above on these dates to identify the most important variables driving differences in community structure. Next, because mean seagrass cover within $100 \mathrm{~m}$ was suspected to be one of the most important variables explaining community structure, I a priori grouped sites into "high" (reefs 1, 5, 11, 13, 20; mean seagrass cover within $100 \mathrm{~m}>20 \%)$ and "low" $(8,9,10,18$; mean seagrass cover within $100 \mathrm{~m}<20 \%$ ) seagrass groups. A Similarity Percentages (SIMPER) analysis was used to determine which fish taxa were most important in driving differences between these two groups for the last three survey dates (PRIMER $\subset$ v 6 , Clarke 1993). The SIMPER analysis uses similarity matrices of fish abundance data and examines which species contribute most to the Bray-Curtis dissimilarity between groups of reefs (high and low seagrass). 
Next, I examined the relationship of species richness and fish abundance with habitat variables. For the following analyses, I took the mean of species richness and fish abundance estimates for each reef across the last three survey dates. To reduce the number of predictor variables used, all habitat variables were grouped by factor analysis to account for co-linearity. A principal component analysis was used to generate orthogonal axes of habitat variables. Next an equimax rotation of principal component axes was performed to reduce the number of axes and number of variables loading heavily onto these axes (SPSS ${ }$ v 14.0, SPSS, Inc. (2005). Separate General Linear Models were used to analyze the relationship between each of the following biotic variables: species richness (all taxa), abundance of all fishes, abundance of benthic fishes, abundance of small fishes $(\leq 5 \mathrm{~cm})$ or large fishes $(>15 \mathrm{~cm})$, with habitat components ( $\mathrm{n}=3$ principal component axes) using SAS ${ }^{\circledR}$ software v 9.2 (Institute 2007). I calculated $\eta^{2}$, the proportion of variation in the biotic variable explained by each predictor, as a measure of effect size. I used partial regression plots to graphically illustrate the relationship between principal component axes and biotic variables. These plots are useful in isolating the effect of a given predictor variable when multiple predictor variables are used, and the slope of the line for each plot is equal to the parameter estimate for a given predictor variable (Velleman \& Welsch 1981; Draper \& Smith 1998). 


\section{Results}

An estimated 13,969 fishes representing 59 different taxa were recorded in surveys on the 12 sampling dates. Of these, 7,344 individuals in 45 taxa were classified as benthic. Over $95 \%$ of all benthic fishes observed were: White grunt, settlement size unidentified grunt (Haemulon spp.), Slippery dick (Halichoeres bivittatus), French grunt (Haemulon flavolineatum), Juvenile parrotfish (Sparisoma spp.), Reef squirrelfish (Sargocentron coruscum), Surgeon fish (Acanthurus chirurgus amd A. bahianus), Cottonwick (Haemulon melanurum), Blue tang (Acanthurus coeruleus), Squirrelfish (Holocentrus adscensionis), Spotted goatfish (Pseudupeneus maculatus), Beaugregory (Stegastes leucostictus), Blackear wrasse (Halichoeres poeyi), unidentified drum (Equetus spp.), Gray snapper (Lutjanus griseus), and Stoplight parrotfish (Sparisoma viride).

Fish community assembly

The relationship between time and species richness was best modeled by a sigmoidal curve $\left(\mathrm{Y}=17.53\left(1+\mathrm{e}^{-(\mathrm{x}-68.75) / 32.03}\right), d f=2, r^{2}=0.95, P<0.0001\right.$, Fig. 2.3a). The relationship between time and $\ln$ (benthic fish abundance) was best modeled by an exponential, asymptotic curve $\left(\mathrm{Y}=2.08+2.87\left(1-0.98^{\mathrm{X}}\right), d f=2, r^{2}=0.91, P<0.0001\right.$, Fig, 2b). Both models appeared to reach an asymptote by the end of the study period (Fig. 2.3). 
Community structure shifted over time, as communities were relatively similar across the beginning survey dates (days 1,7 ), then became less similar to one another, followed by a period of relatively similarity during the last 3 survey dates (Fig. 2.4). The relationship between day following reef creation and the correlation between habitat variables and benthic fish community structure was best represented by a quadratic function, although this model was only marginally significant, with time explaining $47 \%$ of the variation in the correlation $\left(\mathrm{Y}=0.18+0.0049 \mathrm{X}+0.000014 \mathrm{X}^{2}, d f=2, r^{2}=0.47, P\right.$ $=0.055$, Fig. $2.3 \mathrm{c})$.

On the basis of results from the previous analyses, I considered the fish community over the last three survey dates to be relatively stable, as species richness and fish abundance had both reached an asymptote, and community structure was changing relatively little among survey dates (Fig. 2.4). On the last three survey dates (days 152259), the spearman rank correlation between the habitat variables and fish community structure ranged between 0.438 and 0.819 (BIOENV, Table 2.2). While multiple habitat variables were important in explaining differences in fish community structure among reefs, mean seagrass cover within $100 \mathrm{~m}$ was among the most important on all 3 dates, and was only the only habitat variable included the best model for all 3 dates.

Twenty-four taxa were found to contribute to differences in community structure between reefs with "high" and "low" amounts of seagrass (SIMPER, contributing to 90\% of the dissimilarity in communities between groups, Table 2.3). The two most important taxa driving differences in community both belonged to one family of benthic, invertivorous fishes (grunts, Haemulidae). White grunts were the most important taxa, being more abundant at "high" seagrass reefs (mean abundance \pm SE, $80.2 \pm 16.4$ 
fish/reef) than on "low" seagrass reefs ( $28.4 \pm 8.4$ fish/reef). The second most important taxon explaining these differences was the French grunt, which were more common on "low" seagrass reefs ("high" seagrass $=10.3 \pm 4.2$ fish/reef vs. "low" seagrass $=19.6 \pm$ 5.9 fish/reef).

Fish abundance and diversity

In the principal component factor analysis, three component axes explained $86.4 \%$ of the variation in habitat variables (Table 2.4). The distance to open ocean and habitat diversity loaded heavily on the first component axis. Reefs that are positively related to this axis are far from larval recruitment sources in more patchy (diverse) seagrass habitat. Mean seagrass cover within $100 \mathrm{~m}$ and depth loaded heavily on the second axis. Reefs that are positively related to this axis are relatively deep with a greater amount of seagrass at the landscape-scale. Only mean seagrass shoot density within $4 \mathrm{~m}$ loaded heavily on the third component axis; reefs positively related to this axis had a greater amount of seagrass at the patch-scale.

Species richness and total fish abundance were not predicted by any of the groupings of habitat variables (Table 2.5, Fig 2.5a-f). In contrast, habitat variables explained $75 \%$ of the total variation in benthic fish abundance, although the overall model was only marginally significant (Table 2.5). Benthic fish abundance was greater on deeper reefs with more seagrass at the landscape scale than shallower reefs with sparse seagrass (Fig. 2.5h). Although less important in predicting benthic fish abundance than cover of seagrass at the landscape and depth, the amount of seagrass at the patch scale 
was also positively related to abundance (Fig $2.5 \mathrm{i})$. The abundance of small fishes $(\leq 5$ $\mathrm{cm})$ was positively related to the amount of seagrass at the landscape scale and reef depth, although this relationship was only marginally significant (Fig 2.5k) and the overall model was not significant (Table 2.5). Abundance of large fishes $(\geq 15 \mathrm{~cm})$ could be predicted by habitat variables (Table 2.5), and was greater on reefs that were in more patchy landscapes that were farther from the open ocean than reefs in more homogenous landscapes and close to the open ocean. Additionally, the abundance of large fishes was great on deeper reef with more seagrass at the landscape-scale than shallow reef surrounded by sparse seagrass.

\section{Discussion}

My data support the idea that even seemingly homogeneous habitat types can have sufficient degrees of intra-habitat variation to drive significant differences in faunal community structure. Both patch- and landscape-scale variables related to the seagrass beds were important predictors of fish community assembly in the artificial reef system. The amount of seagrass at landscape- and patch-scales, as well as habitat patchiness, all emerged as important drivers for various components of fish community assembly. The amount of seagrass at the landscape-scale was the most important variable driving differences in the abundance of fishes (as well as with overall community structure). As such, I provide evidence that links habitat heterogeneity at patch- and landscape-scales to fish community assembly. 
Previous studies of reef fish communities have reported that both stochastic and deterministic processes may be important in determining community assembly. Stochastic processes such as larval supply were at one time thought to be the dominant driver of reef fish community assembly (Sale \& Douglas 1984). But deterministic factors have since been found to be important, including mechanisms such as priority effects (Shulman et al. 1983; Almany 2003), post-settlement mortality (Shulman \& Ogden 1987), and availability of refugia (Hixon \& Beets 1989; Syms \& Jones 2000). In my study, the strength of the relationship between fish community structure and habitat variables changed over time, generally increasing (although the last survey point indicates it may have started to decline by the end of the study period, perhaps a result of seasonal effects associated with the onset colder winter water temperatures). This pattern might be expected if community assembly was at first random, and species interactions and/or habitat associations became stronger over time as fish densities increased (Arrington et al. 2005).

The patterns I found in similarity of fish communities through time supports this notion. Within the first week following reef creation communities were fairly similar, as fishes on reefs were mostly represented by individuals common in surrounding seagrass (e.g., slippery dick wrasse). Next, as larval and other fishes began to recruit to the artificial reefs, communities became less similar to one another, and less similar among sampling dates for a given reef, with stochastic processes apparently driving assembly. Finally, near the end of the survey period, fish communities were similar to one another, and more similar over time, and habitat variables explained a larger portion of the variation in fish communities among reefs. While patch reef fish communities are 
typically dynamic, my results indicate that habitat context can still explain a large proportion of the variability in community assembly once fish densities reach a particular threshold, thereby supporting a model of reef fish community assembly containing both stochastic and deterministic components.

The amount of seagrass at the landscape-scale seemed to be the most important driver of community structure and explained most of the variation in fish abundance once communities had stabilized. For analyses assessing effects of habitat variables on species richness and abundance, principal component analysis could not separate variation in depth completely from variation in seagrass cover at the landscape-scale, likewise between distance to the open ocean and habitat patchiness. However, in these cases, depth $($ percent variation $=16.7 \%)$ and distance to the ocean $(11.5 \%)$ varied less among reefs than variation in the cover $(43.6 \%)$ or patchiness of seagrass $(20.0 \%)$. Further, Gladfelter et al. (1980) found environmental context did not seem to drive differences in community structure for natural patch reefs in St. Croix that varied more in of depth, distance to other structure, and oceanic influence than reefs in my study. Therefore, it is reasonable to assume that seagrass variables were more important in driving the observed differences in fish abundance than these other variables.

Seagrass plays two primary critical roles for fishes. First, seagrass habitat is known to harbor greater densities of benthic invertebrates than unvegetated bottom (Ansari et al. 1991; Nakamura \& Sano 2005), providing more food for benthic invertivores. Similarly, seagrass and associated epiphytes provide a food source for herbivorous fishes (Kirsch et al. 2002). Therefore, greater cover of seagrass likely represents increased food availability for many fish species. Second, seagrass structure 
may provide shelter from predators (Heck et al. 2003). More generally, the relationship between seagrass cover and predation risk likely depends on the body size and behavior of the focal organism. Since most fishes in my study had a relatively small body size, it is reasonable to suspect that protection provided by seagrass structure contributed to the positive relationship between fish abundance and cover of seagrass across the landscape.

In general, landscape-scale effects emerged as more important in predicting fish community structure and the abundance of fishes than patch-scale effects, regardless of fish body size; the result contradicts my original hypothesis, where I predicted that smaller fishes would respond to factors at smaller spatial scales. Small fishes may still be able to move large distances, and thus select optimal habitat, despite their size.

Alternatively, many of the small fishes are juveniles and recruited to these reefs as larvae. Larval fish may select settlement habitat on the basis of based on landscape-scale habitat features that will be important for post-settlement development, possibly using visual, auditory or chemical cues (Montgomery et al. 2001; Atema et al. 2002; Huijbers et al. 2008). Larger fish were also more abundant on reefs with more seagrass at the landscapescale, which may be associated with increased abundance of prey organisms. Large piscivores also may find it easier to locate prey in patchy seagrass (Hovel \& Lipcius 2002), possibly explaining the greater abundance of large piscivores in patchy landscapes.

The high abundance of benthic species on reefs with more seagrass cover at the landscape-scale was primarily driven by the abundance of White grunts. Conversely, the congeneric French Grunt was more abundant on reefs with less seagrass (more sand) at the landscape level. Both species feed on benthic invertebrates in soft bottom habitats 
(Ogden \& Ehrlich 1977; Cocheret de la Moriniere et al. 2003), yet they do not seem to respond to the landscape in the same way. The observed separation in daytime habitat preference may be an effect of habitat partitioning by these two potential competitors for nighttime foraging grounds. These results are consistent with those from a study in the U.S. Virgin Islands that observed partitioning of nocturnal foraging habitat between these two species, with White grunts feeding primarily in seagrass beds and French grunts feeding primarily over sand flats (Ogden \& Ehrlich 1977). These data emphasize the importance of exploring organism-habitat relationships on a species-by-species basis.

I did not see significant differences in species richness among reefs in different landscape contexts. My study only dealt with differences in $\alpha$ diversity, i.e., differences in species diversity among sites within a single habitat type. At 10-100 m spatial scales, structural complexity (which was held constant in this study) has been found to be the most common variable affecting species richness in coral reef ecosystems (Mellin et al. 2009). Similarly, Grober-Dunsmore et al. (2008) found only a weak relationship between species richness and landscape matrices (cover of seagrass) on similar patch reefs. In my study, because the amount of structured habitat was held constant, it is not surprising that I observed no significant difference in diversity measures among reefs.

Recently, ecologists have emphasized the variability within marine habitat types that have long been considered homogenous (Faunce \& Layman 2009; Kraan et al. 2009). Heterogeneity at both patch- and landscape-scales may contribute to these observed differences in structure and function of habitats. To truly link various aspects of ecosystem function accurately to the surrounding landscape, manipulation of both focal habitats and the surrounding landscape would be necessary, although logistically 
prohibitive in most cases. In this study I take a first step towards an experimental approach by utilizing natural spatial variation in landscapes and manipulating the locations of artificial reefs. Reef location did not affect the characteristics of the surrounding landscape, so it is reasonable to assume the difference in community assembly among reefs was driven by differences in the surrounding landscape. This landscape-scale effect may have critical implications for conservation and management efforts, especially as back-reef habitats are included in marine protected area design (Beck et al. 2001; Mumby 2006). More specific habitat characterizations, i.e., more refined than just "mangrove" or "seagrass', may be critical for optimal reserve design (Mumby 2006; Grober-Dunsmore et al. 2009).

Coastal development and land-use change are among the most serious threats to coastal ecosystems (Lotze et al. 2006). Land-use change has the potential to rapidly alter landscape characteristics in these systems, including wide-spread habitat loss or alterations in the spatial arrangement of habitat types (e.g., Orth et al. 2006). Specifically, coastal development may result in increased habitat fragmentation (Montefalcone et al. 2010), which is known to cause loses in ecosystem function and diminished ecosystem services (Bell et al. 2001; Layman et al. 2007). Furthermore, seagrass fragmentation is often concomitant with declines in seagrass cover or decreased spatial coverage (Fonseca \& Bell 1998). My study demonstrates that even subtle changes in landscape characteristics have the potential to alter fish community dynamics in nearshore ecosystems. 
Acknowledgements This project was funded by National Science Foundation OCE \#0746164, a National Science Foundation Graduate Research Fellowship, and a Florida International University Presidential Fellowship. I thank Friends of the Environment, D. Haines and F. DeRosa on Abaco for their logistical support and the Department of Marine Resources of The Bahamas for research permits. Field assistance and help with data management was provided by A. Anton, C.Acevedo, D. Chacin, G. Mineau, L. Pierre, M. Seese, M. Simpson and E. Stoner. Also, I thank J. Trexler for advice on data analysis, M. Donnelly, members of the Layman Lab, J. Fodrie and an anonymous reviewer for their valuable comments on the manuscript. 
Table 2.1 Description of habitat variables measured with range, mean, and standard deviation among reefs.

\begin{tabular}{|c|c|c|c|c|}
\hline Habitat Variable & Explanation & $\begin{array}{l}\text { Spatial } \\
\text { scale }\end{array}$ & Range & $\begin{array}{c}\text { Mean } \pm \\
\text { standard } \\
\text { deviation }\end{array}$ \\
\hline Depth & $\begin{array}{l}\text { Water depth of reef } \\
\text { base at mean low } \\
\text { water }\end{array}$ & Patch & $1.3-2.5 \mathrm{~m}$ & $1.8 \pm 0.3 \mathrm{~m}$ \\
\hline $\begin{array}{l}\text { Mean seagrass } \\
\text { shoot density } \\
\text { within } 4 \mathrm{~m}\end{array}$ & $\begin{array}{l}\text { Density of seagrass } \\
\text { blades averaged } \\
\text { within } 4 \mathrm{~m} \text { of the } \\
\text { reef }\end{array}$ & Patch & $\begin{array}{c}6.1-20.2 \\
\text { blades } / 100 \mathrm{~cm}^{2}\end{array}$ & $\begin{array}{c}15.7 \pm 4.3 \\
\text { blades } / 100 \mathrm{~cm}^{2}\end{array}$ \\
\hline $\begin{array}{l}\text { Mean seagrass } \\
\text { shoot height } \\
\text { within } 4 \mathrm{~m}\end{array}$ & $\begin{array}{l}\text { Height of seagrass } \\
\text { blades averaged } \\
\text { within } 4 \mathrm{~m} \text { of the } \\
\text { reef }\end{array}$ & Patch & $5.5-9.6 \mathrm{~cm}$ & $6.7 \pm 1.6 \mathrm{~cm}$ \\
\hline $\begin{array}{l}\text { Distance to } \\
\text { open ocean }\end{array}$ & $\begin{array}{l}\text { Distance to larval } \\
\text { recruitment source }\end{array}$ & Landscape & $2.1-2.8 \mathrm{~km}$ & $2.6 \pm 0.3 \mathrm{~km}$ \\
\hline $\begin{array}{l}\text { Distance to } \\
\text { structure }\end{array}$ & $\begin{array}{l}\text { Distance to } \\
\text { recruitment source } \\
\text { of non-larval fishes }\end{array}$ & Landscape & $170-950 m$ & $550 \pm 200 \mathrm{~m}$ \\
\hline $\begin{array}{l}\text { Mean seagrass } \\
\text { cover within } \\
100 \mathrm{~m}\end{array}$ & $\begin{array}{l}\text { Mean percent cover } \\
\text { seagrass within } 100 \\
m \text { of each reef }\end{array}$ & Landscape & $\begin{array}{c}15.2-49.3 \% \\
\text { cover }\end{array}$ & $\begin{array}{c}25.7 \pm 11.2 \% \\
\text { cover }\end{array}$ \\
\hline Habitat contrast & $\begin{array}{l}\text { Index of habitat } \\
\text { patchiness; } \\
\text { measures variability } \\
\text { in percent cover of } \\
\text { seagrass between } \\
\text { adjacent cells } \\
\text { within } 100 \mathrm{~m} \text { of } \\
\text { each reef }\end{array}$ & Landscape & $1130-1600$ & $1480 \pm 150$ \\
\hline $\begin{array}{l}\text { Habitat } \\
\text { diversity }\end{array}$ & $\begin{array}{l}\text { Index of diversity } \\
\text { of seagrass patches; } \\
\text { alternate measure } \\
\text { of habitat } \\
\text { patchiness within } \\
100 \text { m of each reef }\end{array}$ & Landscape & $0.6-1.3$ & $1 \pm 0.2$ \\
\hline
\end{tabular}


Table 2.2 Results of BIOENV indicating habitat variables that best explain the differences in community structure among reefs. Day indicates day following reef creation. The best three models for each day are included. $\rho$ represents the Spearman correlation coefficient.

\begin{tabular}{cccc}
\hline Day & Model & $\rho$ & Habitat Variables \\
\hline 152 & 1 & 0.819 & $1,2,3,4$ \\
& 2 & 0.809 & $1,2,3,4,5$ \\
212 & 3 & 0.803 & $1,2,3,5$ \\
& 1 & 0.654 & 1,5 \\
259 & 2 & 0.595 & $1,5,6$ \\
& 3 & 0.586 & 1 \\
& 1 & 0.438 & $1,2,4,5,6$ \\
& 2 & 0.425 & $1,2,6$ \\
& 3 & 0.415 & $2,4,6$ \\
\hline
\end{tabular}

1. Mean seagrass percent cover within $100 \mathrm{~m}$

2. Mean seagrass shoot height within $4 \mathrm{~m}$

3. Habitat contrast

4. Distance to structure

5. Depth

6. Mean seagrass shoot density within $4 \mathrm{~m}$ 
Table 2.3 Results of similarity percentages (SIMPER) analysis examining which species contribute most to the Bray-Curtis dissimilarity between reefs with "high" (mean seagrass cover within $100 \mathrm{~m}>20 \%$ ) and "low" (mean seagrass cover within $100 \mathrm{~m}<$ $20 \%$ ) amounts of seagrass within the landscape. Mean abundance \pm standard error (SE) was calculated across all reefs within each group over the last three survey dates (days 152-259).

\begin{tabular}{|c|c|c|c|c|c|}
\hline $\begin{array}{l}\text { Taxa } \\
\text { common } \\
\text { name }\end{array}$ & $\begin{array}{l}\text { Scientific } \\
\text { name }\end{array}$ & $\begin{array}{c}\text { Mean } \\
\text { abundance } \\
\pm \text { SE for } \\
\text { "high" } \\
\text { seagrass } \\
\text { reefs }\end{array}$ & $\begin{array}{c}\text { Mean } \\
\text { abundance } \\
\pm \text { SE for } \\
\text { "low" } \\
\text { seagrass } \\
\text { reefs }\end{array}$ & $\begin{array}{c}\text { \% } \\
\text { contribution } \\
\text { to difference }\end{array}$ & $\begin{array}{c}\text { Cumulative } \\
\% \\
\text { difference }\end{array}$ \\
\hline White grunt & $\begin{array}{l}\text { Haemulon } \\
\text { plumierii }\end{array}$ & $80.2 \pm 16.4$ & $28.4 \pm 8.4$ & 16.1 & 16.1 \\
\hline French grunt & $\begin{array}{l}\text { Haemulon } \\
\text { flavolineatum }\end{array}$ & $10.3 \pm 4.2$ & $19.6 \pm 5.9$ & 10.8 & 26.9 \\
\hline $\begin{array}{l}\text { Slippery } \\
\text { dick }\end{array}$ & $\begin{array}{l}\text { Halichoeres } \\
\text { bivittatus }\end{array}$ & $9.5 \pm 2.6$ & $12.7 \pm 3.4$ & 6.5 & 33.5 \\
\hline $\begin{array}{l}\text { Juvenile } \\
\text { parrotfish }\end{array}$ & Sparisoma spp. & $5.9 \pm 1.8$ & $7.9 \pm 3.5$ & 5.7 & 39.2 \\
\hline Cottonwick & $\begin{array}{l}\text { Haemulon } \\
\text { melanurum }\end{array}$ & $1.3 \pm 0.6$ & $3.7 \pm 1.7$ & 5.0 & 44.2 \\
\hline Surgeonfish & $\begin{array}{l}\text { Acanthurus } \\
\text { spp. }\end{array}$ & $4.5 \pm 1.2$ & $5.6 \pm 0.7$ & 4.5 & 48.7 \\
\hline $\begin{array}{l}\text { Juvenile } \\
\text { grunt }\end{array}$ & Haemulon spp. & $1.2 \pm 0.7$ & $3.5 \pm 2.4$ & 4.2 & 52.9 \\
\hline Blue tang & $\begin{array}{l}\text { Acanthurus } \\
\text { coeruleus }\end{array}$ & $2.9 \pm 0.7$ & $3.4 \pm 0.9$ & 3.5 & 56.4 \\
\hline Squirrelfish & $\begin{array}{l}\text { Holocentrus } \\
\text { adscensionis }\end{array}$ & $1.5 \pm 0.5$ & $1.5 \pm 0.5$ & 3.3 & 59.7 \\
\hline $\begin{array}{l}\text { Lane } \\
\text { snapper }\end{array}$ & $\begin{array}{l}\text { Lutjanus } \\
\text { synagris }\end{array}$ & $0.2 \pm 0.1$ & $1.1 \pm 0.3$ & 3.0 & 62.7 \\
\hline
\end{tabular}




\begin{tabular}{|c|c|c|c|c|c|}
\hline Beaugregory & $\begin{array}{l}\text { Stegastes } \\
\text { leucostictus }\end{array}$ & $1.1 \pm 0.2$ & $1.7 \pm 0.5$ & 3.0 & 65.7 \\
\hline $\begin{array}{l}\text { Gray } \\
\text { snapper }\end{array}$ & $\begin{array}{l}\text { Lutjanus } \\
\text { griseus }\end{array}$ & $0.7 \pm 0.4$ & $1.1 \pm 0.5$ & 2.9 & 68.6 \\
\hline $\begin{array}{l}\text { Reef } \\
\text { squirrelfish }\end{array}$ & $\begin{array}{l}\text { Sargocentron } \\
\text { coruscum }\end{array}$ & $6.5 \pm 1.0$ & $5.4 \pm 0.8$ & 2.7 & 71.2 \\
\hline $\begin{array}{l}\text { Stoplight } \\
\text { parrotfish }\end{array}$ & $\begin{array}{l}\text { Sparisoma } \\
\text { viride }\end{array}$ & $1.0 \pm 0.3$ & $0.8 \pm 0.2$ & 2.5 & 73.7 \\
\hline $\begin{array}{l}\text { French } \\
\text { angelfish }\end{array}$ & $\begin{array}{l}\text { Pomacanthus } \\
\text { paru }\end{array}$ & $0.0 \pm 0.0$ & $1.3 \pm 1.0$ & 2.4 & 76.1 \\
\hline Drum & Equetus spp. & $0.9 \pm 0.3$ & $0.5 \pm 0.3$ & 2.4 & 78.5 \\
\hline $\begin{array}{l}\text { Blackear } \\
\text { wrasse }\end{array}$ & $\begin{array}{l}\text { Halichoeres } \\
\text { poeyi }\end{array}$ & $0.6 \pm 0.3$ & $0.4 \pm 0.2$ & 2.0 & 80.5 \\
\hline $\begin{array}{l}\text { Queen } \\
\text { angelfish }\end{array}$ & $\begin{array}{l}\text { Holacanthus } \\
\text { ciliaris }\end{array}$ & $0.5 \pm 0.1$ & $0.6 \pm 0.3$ & 1.9 & 82.4 \\
\hline $\begin{array}{l}\text { Yellow } \\
\text { goatfish }\end{array}$ & $\begin{array}{l}\text { Mulloidichthys } \\
\text { martinicus }\end{array}$ & $0.0 \pm 0.0$ & $1.3 \pm 1.1$ & 1.9 & 84.3 \\
\hline Lionfish & $\begin{array}{l}\text { Pterois } \\
\text { volitans }\end{array}$ & $0.5 \pm 0.2$ & $0.5 \pm 0.2$ & 1.9 & 86.2 \\
\hline Bluehead & $\begin{array}{l}\text { Thalassoma } \\
\text { bifasciatum }\end{array}$ & $0.7 \pm 0.5$ & $0.1 \pm 0.1$ & 1.3 & 87.5 \\
\hline $\begin{array}{l}\text { Blue } \\
\text { parrotfish }\end{array}$ & $\begin{array}{l}\text { Scarus } \\
\text { coeruleus }\end{array}$ & $0.3 \pm 0.2$ & $0.4 \pm 0.2$ & 1.2 & 88.7 \\
\hline Goby & Gobiidae & $0.2 \pm 0.1$ & $0.3 \pm 0.2$ & 1.1 & 89.8 \\
\hline $\begin{array}{l}\text { Sharpnose } \\
\text { puffer }\end{array}$ & $\begin{array}{l}\text { Canthigaster } \\
\text { rostrata }\end{array}$ & $0.3 \pm 0.1$ & $0.1 \pm 0.1$ & 1.1 & 90.9 \\
\hline
\end{tabular}


Table 2.4 Loadings for variables making up principal components from factor analysis of habitat variables relating to each reef. * values indicate the strongest explanatory variable(s) for each component.

\begin{tabular}{lccc}
\hline & \multicolumn{3}{c}{ Component } \\
\cline { 2 - 4 } Variable & 1 & 2 & 3 \\
\hline Depth & 0.08 & $0.88^{*}$ & -0.02 \\
Shoot Density 4 m & -0.16 & 0.06 & $0.94^{*}$ \\
Shoot Height 4 m & 0.58 & 0.19 & 0.73 \\
Distance to Ocean & $0.88^{*}$ & -0.08 & -0.25 \\
Distance to Structure & 0.60 & 0.74 & 0.19 \\
Percent Cover 100 m & -0.15 & $0.85^{*}$ & 0.50 \\
Habitat Diversity & $0.93^{*}$ & 0.09 & 0.27 \\
Habitat Contrast & 0.65 & 0.42 & -0.04 \\
\hline Percent variation & 35.0 & 28.4 & 23.0 \\
\hline
\end{tabular}


Table 2.5 Results of General Linear Models of species richness and different abundance measures predicted by principal component groupings of habitat variables. Source $=$ source of variation, $d f=$ degrees of freedom, $\mathrm{MS}=$ mean squares, $\mathrm{F}=\mathrm{F}$-statistic, $P=P$ value based on F-test, $\eta^{2}=$ proportion of variation in dependent variable explained by each predictor, $\mathrm{C}=$ component.

\begin{tabular}{lccccccccccc}
\hline \multicolumn{3}{c}{ Overall Model } & \multicolumn{7}{c}{ Individual Predictors } \\
\hline Source & $d f$ & MS & F & $P$ & Source & $d f$ & MS & F & $P$ & $\eta^{2}$ \\
\hline \multicolumn{2}{l}{ 1. Species Richness, $R^{2}=0.20$} & & & & & & & \\
Model & 3 & 4.42 & 0.41 & 0.75 & C 1 & 1 & 11.06 & 1.04 & 0.36 & 0.17 \\
Error & 5 & 10.7 & & & C 2 & 1 & 0.34 & 0.03 & 0.87 & 0.01 \\
& & & & & C 3 & 1 & 1.86 & 0.17 & 0.69 & 0.03
\end{tabular}

2. Total Fish Abundance, $R^{2}=0.13$

$\begin{array}{lllllllllll}\text { Model } & 3 & 5554.1 & 0.26 & 0.85 & \text { C } 1 & 1 & 12069.73 & 0.56 & 0.49 & 0.10 \\ \text { Error } & 5 & 21534.6 & & & \text { C 2 } & 1 & 3398.56 & 0.16 & 0.71 & 0.03 \\ & & & & & \text { C 3 } & 1 & 1194.07 & 0.06 & 0.82 & 0.01\end{array}$

3. Benthic Fish Abundance, $R^{2}=0.75$

$\begin{array}{lllllllllll}\text { Model } & 3 & 3932.1 & 4.94 & 0.059 & \text { C } 1 & 1 & 709.78 & 0.89 & 0.39 & 0.05\end{array}$

$\begin{array}{lllllllll}\text { Error } & 5 & 796.0 & \text { C } 2 & 1 & 7418.38 & 9.32 & 0.028 & 0.47\end{array}$

$\begin{array}{llllll}\text { C } 3 & 1 & 3668.05 & 4.61 & 0.085 & 0.23\end{array}$

4. Small Fish Abundance, $R^{2}=0.57$

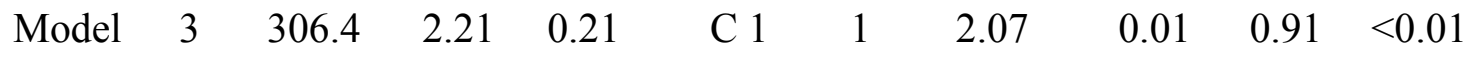

$\begin{array}{lllllllll}\text { Error } & 5 & 138.8 & \text { C } 2 & 1 & 719.02 & 5.18 & 0.072 & 0.45\end{array}$

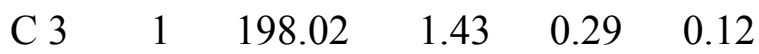

5. Large Fish Abundance, $R^{2}=0.82$

$\begin{array}{lllllllllll}\text { Model } & 3 & 110.8 & 7.42 & 0.027 & \text { C } 1 & 1 & 100.39 & 6.73 & 0.048 & 0.25 \\ \text { Error } & 5 & 14.9 & & & \text { C 2 } & 1 & 222.48 & 14.91 & 0.012 & 0.55 \\ & & & & & \text { C 3 } & 1 & 9.61 & 0.64 & 0.46 & 0.02\end{array}$




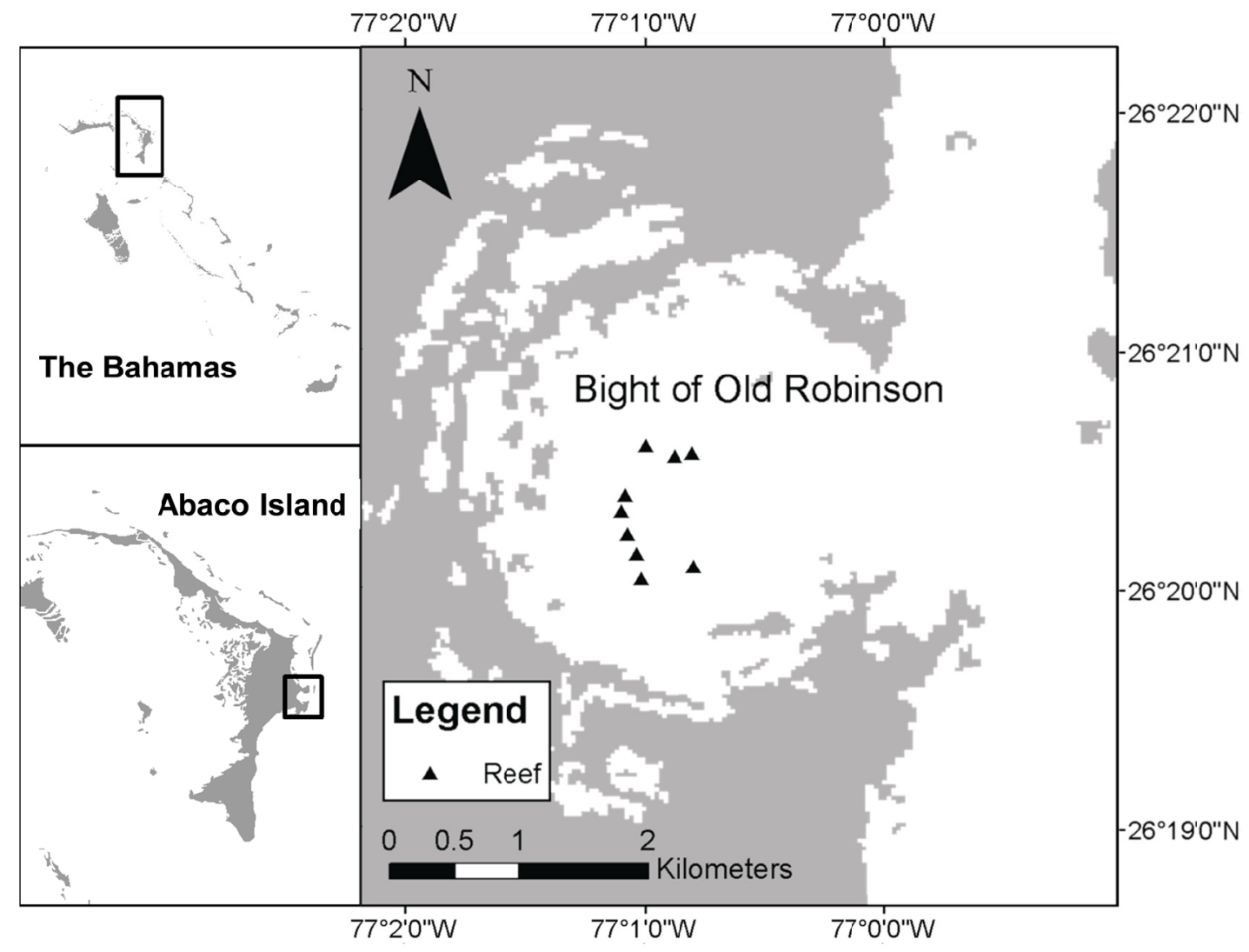

Fig. 2.1 Map of study area showing the locations of artificial reefs within the Bight of Old Robison, Abaco Island, Bahamas. 


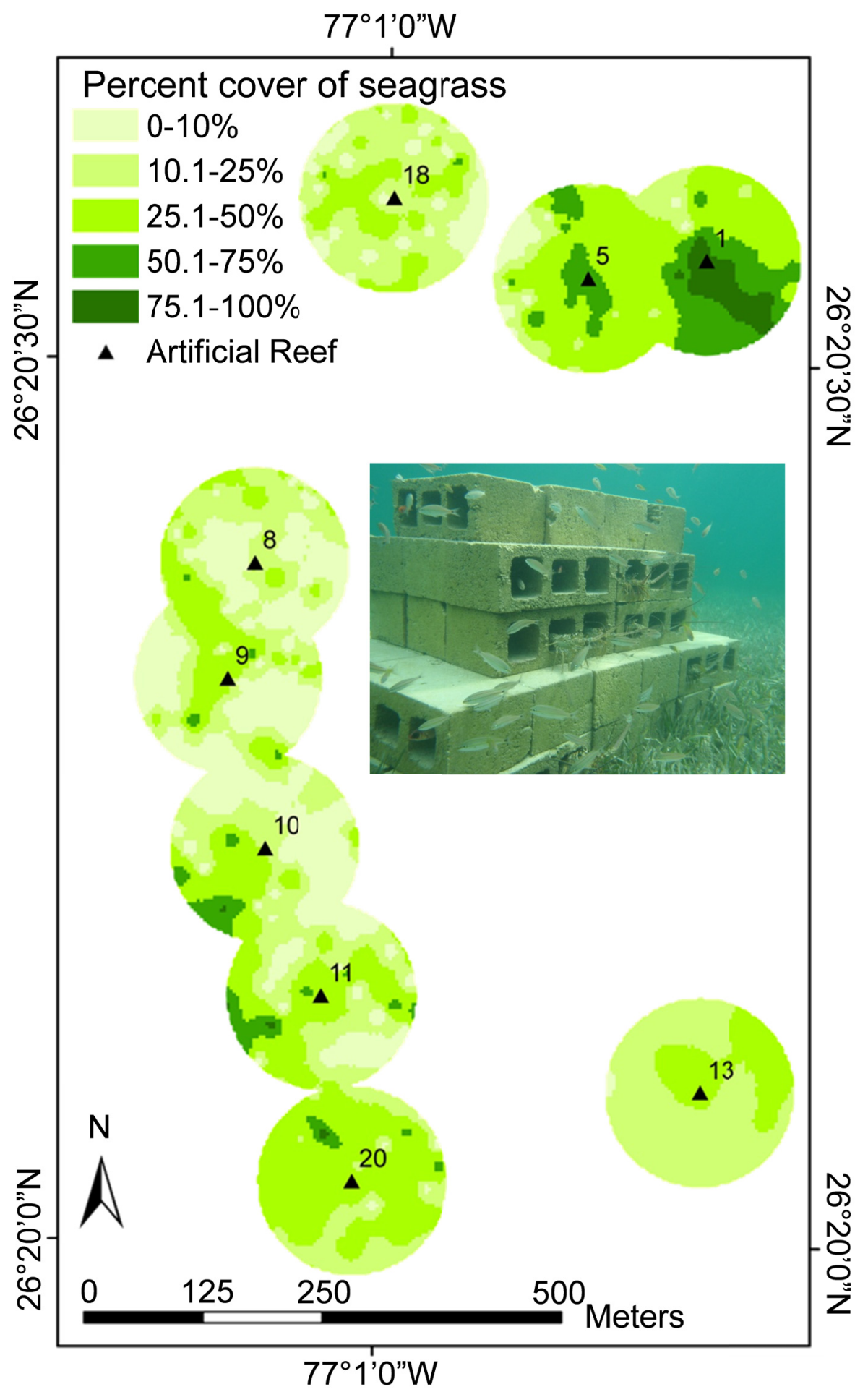

Fig. 2.2 Map of study site showing locations and seagrass cover surrounding artificial reefs. Inset picture shows an artificial reef 3 months after construction (June 2009). Each reef is identified by a solid triangle and number. Reefs were located in the Bight of Old Robison, Abaco Island, Bahamas (Fig 2.1). 

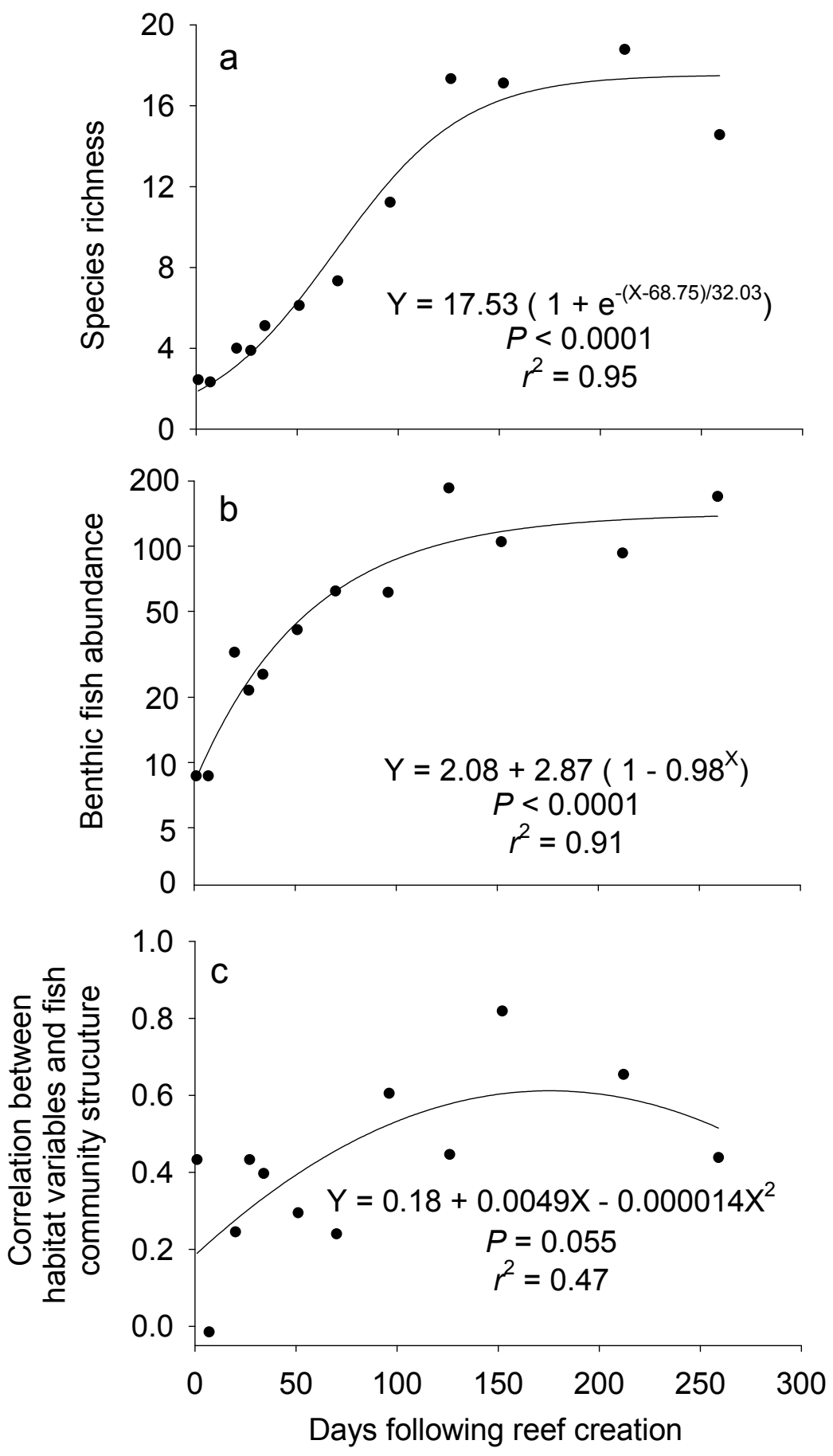

Fig. 2.3 Trajectory of (a) species richness, (b) benthic fish abundance (mean \# fish/reef), and (c) the correlation between habitat variables and fish community structure through time. Note y-axis of (b) is plotted on a natural log scale but labels are back-transformed to represent true abundance values. 


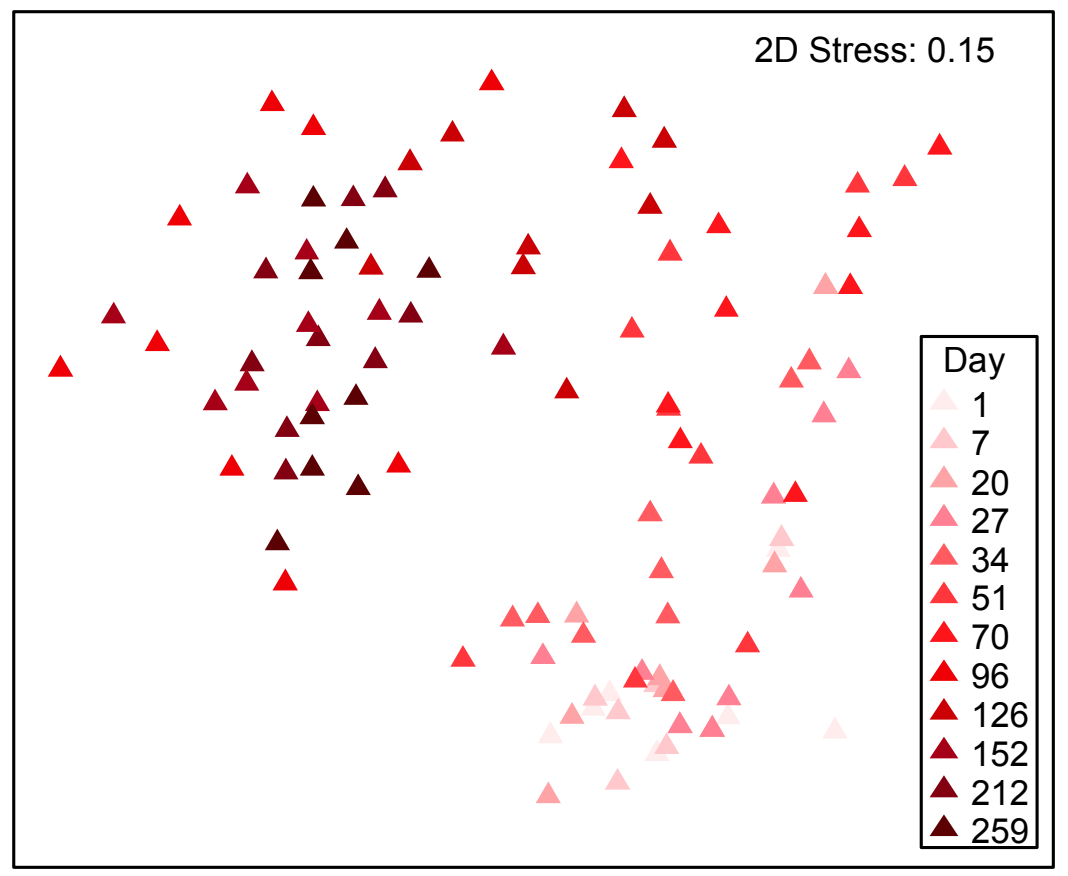

Fig. 2.4 Non-metric Multidimensional Scaling plot of community structure on reefs through time. Triangles represent an individual survey for each reef $(n=9$ per day $)$ and are shaded according to survey date. 

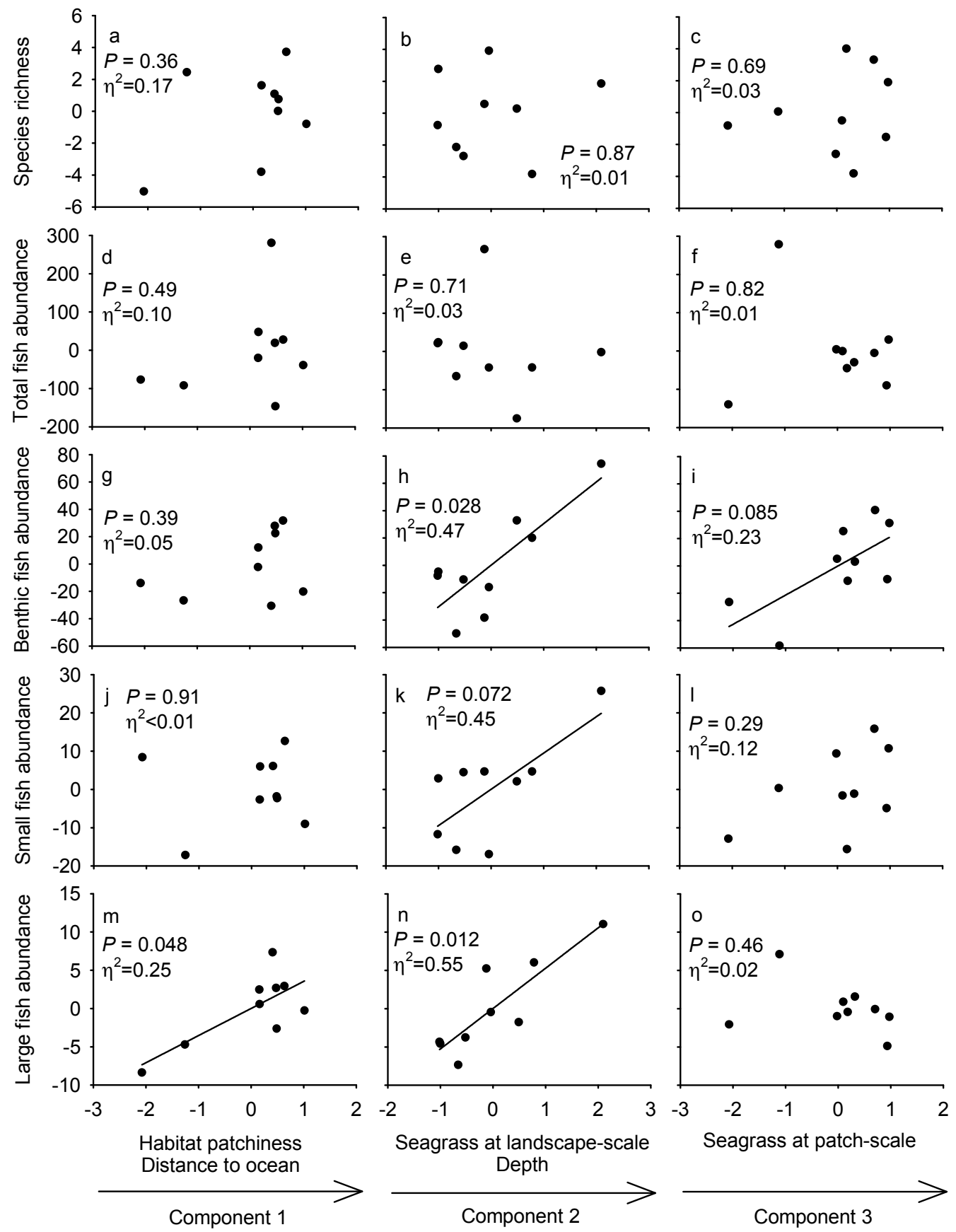

Fig. 2.5 Partial regression plots derived from General Linear Models showing the relationship between principal component axes of habitat variables (x axes) and (a-c) species richness, (d-f) total fish abundance, (g-i) benthic fish abundance, (j-1) small fish $(\leq 5 \mathrm{~cm} \mathrm{TL})$ abundance and $(\mathrm{m}-\mathrm{o})$ large fish $(\geq 15 \mathrm{~cm} \mathrm{TL})$ abundance. The habitat variables loading most heavily on each principal component are listed under the $\mathrm{x}$-axes. $P$-values are included for each parameter as well as $\eta^{2}$, i.e., the proportion of total variation explained by each component. Trend lines are shown for significant and marginally significant $(P<0.1)$ relationships. 


\section{Literature cited}

Alevizon WS, Gorham JC, Richardson R, Mccarthy SA (1985) Use of Man-Made Reefs to Concentrate Snapper (Lutjanidae) and Grunts (Haemulidae) in Bahamian Waters. Bulletin of Marine Science 37:3-10

Almany GR (2003) Priority effects in coral reef fish communities. Ecology 84:1920-1935

Ansari ZA, Rivonker CU, Ramani P, Parulekar AH (1991) Seagrass Habitat Complexity and Macroinvertebrate Abundance in Lakshadweep Coral-Reef Lagoons, Arabian Sea. Coral Reefs 10:127-131

Arrington DA, Winemiller KO, Layman CA (2005) Community assembly at the patch scale in a species rich tropical river. Oecologia 144:157-167

Atema J, Kingsford M, Gerlach G (2002) Larval reef fish could use odour for detection, retention and orientation to reefs. Marine Ecology Progress Series 241:151-160

Beck M et al. (2001) The identification, conservation, and management of estuarine and marine nurseries for fish and invertebrates. Bioscience 51:633-641

Bell SS, Brooks RA, Robbins BD, Fonseca MS, Hall MO (2001) Faunal response to fragmentation in seagrass habitats: implications for seagrass conservation. Biological Conservation 100:115-123

Clarke KR (1993) Non-parametric multivariate analyses of changes in community structure. Australian Journal of Ecology 18:117-143

Clarke KR, Gorley RN (2006) PRIMER v6. In. PRIMER-E, Plymouth, UK

Cocheret de la Moriniere E, Pollux BJA, Nagelkerken I, van der Velde G (2003) Diet shifts of Caribbean grunts (Haemulidae) and snappers (Lutjanidae) and the relation with nursery-to-coral reef migrations. Estuarine Coastal and Shelf Science 57:1079-1089

Debinski DM, Holt RD (2000) Review: a survey and overview of habitat fragmentation experiments. Conservation Biology 14:342-355

Draper N, Smith H (1998) Applied Regression Analysis, $3^{\text {rd }}$ ed. John Wiley \& Sons, New York, USA. pp 706.

ERSI (2008) ArcGIS v 9, Redlands, CA USA

Faunce CH, Layman CA (2009) Sources of variation that affect perceived nursery function in mangroves. In: Nagelkerken I (ed) Ecological Linkages across Tropical Coastal Ecosystems. Springer, New York, USA, pp 401-421 
Fonseca M, Whitfield PE, Kelly NM, Bell SS (2002) Modeling seagrass landscape pattern and associated ecological attributes. Ecological Applications 12:218-237

Fonseca MS, Bell SS (1998) Influence of physical setting on seagrass landscapes near Beaufort, North Carolina, USA. Marine Ecology-Progress Series 171:109-121

Fourqurean JW, Willsie A, Rose CD, Rutten LM (2001) Spatial and temporal pattern in seagrass community composition and productivity in south Florida. Marine Biology 138:341-354

Gladfelter WB, Ogden JC, Gladfelter EH (1980) Similarity and diversity among coral reef fish communities: a comparison between Tropical Western Atlantic (Virgin Islands) and Tropical Central Pacific (Marshall Islands) patch reefs Ecology 61:1156-1168

Google, Inc. (2010) Google Earth®, v 5.1.

Grabowski JH, Hughes AR, Kimbro DL, Dolan MA (2005) How habitat setting influences restored oyster reef communities. Ecology 86:1926-1935

Grober-Dunsmore R, Frazer TK, Beets JP, Lindberg WJ, Zwick P, Funicelli NA (2008) Influence of landscape structure on reef fish assemblages. Landscape Ecology $23: 37-53$

Grober-Dunsmore R, Pittman SJ, Caldow C, Kendall MS, Frazer TK (2009) A landscape ecology approach for the study of ecological connectivity across tropical marine seascapes. In: Nagelkerken I (ed) Ecological Connectivity among Tropical Coastal Ecosystems. Springer, pp 493-530

Gunst RF, Mason RL. 1980. Regression analysis and its application: a data-oriented approach. Marcel Dekker, Inc. New York, USA. pp 403.

Heck K, Hays G, Orth RJ (2003) Critical evaluation of the nursery role hypothesis for seagrass meadows. Marine Ecology Progress Series 253:123-136

Hixon MA, Beets JP (1989) Shelter Characteristics and Caribbean Fish Assemblages Experiments with Artificial Reefs. Bulletin of Marine Science 44:666-680

Hovel KA, Fonseca MS (2005) Influence of seagrass landscape structure on the juvenile blue crab habitat-survival function. Marine Ecology-Progress Series 300:179-191

Hovel KA, Lipcius RN (2002) Effects of seagrass habitat fragmentation on juvenile blue crab survival and abundance. Journal of Experimental Marine Biology and Ecology 271:75-98

Huijbers C, Mollee E, Nagelkerken I (2008) Post-larval French grunts (Haemulon flavolineatum) distinguish between seagrass, mangrove and coral reef water: 
implicaltions for recognition of potential nursery habitats. journal of Experimental Marine Biology and Ecology 357:134-139

Ims RA (2005) The role of experiments in landscape ecology. In: Wiens JA, Moss MR (eds) Issues and Perspectives in Landscape Ecology. Cambridge University Press, Cambridge, UK, pp 70-78

Irlandi EA (1994) Large-Scale and Small-Scale Effects of Habitat Structure on Rates of Predation - How Percent Coverage of Seagrass Affects Rates of Predation and Siphon Nipping on an Infaunal Bivalve. Oecologia 98:176-183

Irlandi EA, Ambrose WG, Orlando BA (1995) Landscape Ecology and the MarineEnvironment - How Spatial Configuration of Seagrass Habitat Influences Growth and Survival of the Bay Scallop. Oikos 72:307-313

Irlandi EA, Crawford MK (1997) Habitat linkages: The effect of intertidal saltmarshes and adjacent subtidal habitats on abundance, movement, and growth of an estuarine fish. Oecologia 110:222-230

Kendall MS, Christensen JD, Hillis-Starr Z (2003) Multi-scale data used to analyze the spatial distribution of French grunts, Haemulon flavolineatum, relative to hard and soft bottom in a benthic landscape. Environmental Biology of Fishes 66:19-26

Kirsch KD, Valentine JF, Heck KL (2002) Parrotfish grazing on turtlegrass Thalassia testudinum: evidence for the importance of seagrass consumption in food web dynamics of the Florida Keys National Marine Sanctuary. Marine EcologyProgress Series 227:71-85

Kraan C, van der Meer J, Dekinga A, Piersma T (2009) Patchiness of macrobenthic invertebrates in homogenized intertidal habitats: hidden spatial structure at a landscape scale. Marine Ecology-Progress Series 383:211-224

Layman CA, Arrington DA, Langerhans RB, Silliman BR (2004) Degree of fragmentation affects fish assemblage structure in Andros Island (Bahamas) estuaries. Caribbean Journal of Science 40:232-244

Layman CA, Quattrochi JP, Peyer CM, Allgeier JE (2007) Niche width collapse in a resilient top predator following ecosystem fragmentation. Ecology Letters 10:937944

Layman CA, Silliman BR (2002) Preliminary survey and diet analysis of juvenile fishes of an estuarine creek on Andros Island, Bahamas. Bulletin of Marine Science $70: 199-210$

Levin SA (1992) The problem of pattern and scale in ecology. Ecology 73:1943-1967 
Lirman D, Cropper WP, Jr. (2003) The influence of salinity on seagrass growth, survivorship and distribution within Biscayne Bay, Florida: field, experimental and modeling studies. Estuaries 26:131-141

Lotze HK et al. (2006) Depletion, degradation, and recovery potential of estuaries and coastal seas. Science 312:1806-1809

Luo JG, Serafy JE, Sponaugle S, Teare PB, Kieckbusch D (2009) Movement of gray snapper Lutjanus griseus among subtropical seagrass, mangrove, and coral reef habitats. Marine Ecology-Progress Series 380:255-269

McGarigal K, Cushman SA, MNeel MC, Ene E (2002) FRAGSTATS: Spatital Pattern Analysis Program for Categorical Maps. In, 3.3 edn. University of Massachusetts

Mellin C, Andrefouet S, Kulbicki M, Dalleau M, Vigliola L (2009) Remote sensing and fish-habitat relationships in coral reef ecosystems: Review and pathways for systematic multi-scale hierarchical research. Marine Pollution Bulletin 58:11-19

Miller MW (2002) Using ecological processes to advance artificial reef goals. Ices Journal of Marine Science 59:S27-S31

Montefalcone $\mathrm{M}$ et al. (2010) Human influence on seagrass habitat fragmentation in NW Mediterranean Sea. Estuarine Coastal and Shelf Science 86:292-298

Montgomery J, Tolimieri N, Haine O (2001) Active habitat selection by pre-settlement reef fishes. Fish and Fisheries 2:261-277

Mumby PJ (2006) Connectivity of reef fish between mangroves and coral reefs: Algorithms for the design of marine reserves at seascape scales. Biological Conservation 128:215-222

Nagelkerken I, Dorenbosch M, Verberk WCEP, de la Moriniere EC, van der Velde G (2000a) Day-night shifts of fishes between shallow-water biotopes of a Caribbean bay, with emphasis on the nocturnal feeding of Haemulidae and Lutjanidae. Marine Ecology-Progress Series 194:55-64

Nagelkerken I, van der Velde G, Gorissen MW, Meijer GJ, van't Hof T, den Hartog C (2000b) Importance of mangroves, seagrass beds and the shallow coral reef as a nursery for important coral reef fishes, using a visual census technique. Estuarine Coastal and Shelf Science 51:31-44

Nakamura Y, Sano M (2005) Comparison of invertebrate abundance in a seagrass bed and adjacent coral and sand areas at Amitori Bay, Iriomote Island, Japan. Fisheries Science 71:543-550

Ogden JC, Ehrlich PR (1977) Behavior of Heterotypic Resting Schools of Juvenile Grunts (Pomadasyidae). Marine Biology 42:273-280 
Orth RJ et al. (2006) A global crisis for seagrass ecosystems. Bioscience 56:987-996

Pickett STA, Cadenasso ML (1995) Landscape Ecology - Spatial Heterogeneity in Ecological-Systems. Science 269:331-334

Pielou EC (1966) The measurement of diversity in different types of biological collections. Journal of Theoretical Biology 13:131-144

Pittman SJ, Caldow C, Hile SD, Monaco ME (2007) Using seascape types to explain the spatial patterns of fish in the mangroves of SW Puerto Rico. Marine EcologyProgress Series 348:273-284

Pittman SJ, McAlpine CA, Pittman KM (2004) Linking fish and prawns to their environment: a hierarchical landscape approach. Marine Ecology-Progress Series $283: 233-254$

Randall JE (1967) Food habitat of reef fishes of the West Indies. Stud. Trop. Oceanogr. 5:665-847

Robbins BD, Bell SS (1994) Seagrass Landscapes - a Terrestrial Approach to the Marine Subtidal Environment. Trends in Ecology \& Evolution 9:301-304

Sale PF, Douglas WA (1984) Temporal variability in the community structure of fish on coral patch reefs and the relation of community structure to reef structure. Ecology 65:409-422

Sandel B, Smith AB (2009) Scale as a lurking factor: incorporating scale-dependence in experimental ecology. Oikos 118:1284-1291

SAS Institute (2007) SAS v 9.2, Cary, NC USA

Schneider DC (2001) The rise of concept of scale in ecology. Bioscience 51:545-553

Shulman MJ (1985) Recruitment of coral reef fishes: Effects of distribution of predators and shelter. Ecology 66:1056-1066

Shulman MJ, Ogden JC (1987) What controls tropical reef fish populations: recruitment or bethic mortality? An example in the Caribbean reef fish Haemulon flavolineatum Marine Ecology-Progress Series 39:233-242

Shulman MJ, Ogden JC, Ebersole JP, McFarland WN, Miller SL, Wolf NG (1983) Priority effects in the recruitment of juvenile coral reef fishes. Ecology 64:15081513

SPSS, Inc (2005) SPSS v 14.0, Chicago, IL USA 
Syms C, Jones GP (2000) Disturbance, habitat structure, and the dynamics of a coral-reef fish community. Ecology 81:2714-2729

Turner MG (1989) Landscape Ecology - the Effect of Pattern on Process. Annual Review of Ecology and Systematics 20:171-197

Velleman P, Welsch R (1981) Efficient computing of regression diagnostics. The American Statistician 35:234-242

Wu JG, Hobbs R (2002) Key issues and research priorities in landscape ecology: An idiosyncratic synthesis. Landscape Ecology 17:355-365 


\section{CHAPTER III}

\section{EFFECTS OF SEASCAPE CONTEXT ON CONDITION, ABUNDANCE, AND SECONDARY PRODUCTION OF A CORAL REEF FISH}




\section{ABSTRACT:}

Variation in seascape composition has the potential to impact habitat quality for fishes, and characteristics of the surrounding seascape have been correlated with abundance of organisms in many systems. How seascape context may affect other aspects of habitat quality including growth, condition, or production of focal species has not been well-studied. Juvenile White grunts (Haemulon plumierii) are known to rest on patch reefs during the day and move into seagrass habitat at night to feed, linking multiple habitats through these daily foraging migrations. I created artificial reefs across a gradient of seagrass cover and determined the relationship between juvenile White grunt condition, growth, abundance, and secondary production with seagrass cover within the seascape. White grunt abundance was positively correlated with the cover of seagrass within the seascape, while condition (relative condition factor, $\mathrm{K}_{\mathrm{n}}$ ) and growth rate (measured using RNA:DNA) did not vary among reefs within different seascapes. Secondary production of White grunts was found to be highest on reefs in seascapes with dense seagrass. My results are consistent with the hypothesis that increased food resources associated with higher seagrass cover contributed to increased grunt production. However, differences in habitat quality among reefs in different seascapes were manifest at the population (abundance) and ecosystem function (secondary production) levels, and not at the individual level (individual growth rate or condition factor). These results highlight the importance of considering multiple levels of individual and population responses in assessments of habitat quality, and add evidence 
that seascape composition should be considered in spatially-explicit management strategies.

KEY WORDS: artificial reef, fitness, Haemulon plumierii, landscape, predator-prey dynamics, RNA:DNA, seagrass 


\section{INTRODUCTION}

Landscape ecology is a useful framework to examine the consequences of spatial heterogeneity on aspects of ecosystem structure and function (Turner 1989, 2005a), and the same approaches are increasingly applied in marine systems. In the marine context, a seascape may be defined as an area of heterogeneous habitat that can be viewed at a range of spatial scales, and the seascape context of a focal patch is the position of the patch relative to surrounding seascape elements (Grober-Dunsmore et al. 2009). The surrounding seascape has the potential to influence access to resources, exposure to predators, or connectivity among habitats, and therefore can be a central driver of local habitat quality (Sheaves \& Johnston 2009). Many studies have used this framework to link variation in organismal abundance and diversity in focal patches to the seascape context (Robbins \& Bell 1994; Irlandi et al. 1995; Hovel \& Lipcius 2001; Grabowski et al. 2005; Pittman et al. 2007b; Grober-Dunsmore et al. 2008; Yeager et al. 2011).

While the importance of seascape context is increasingly acknowledged in the evaluation of habitat quality, few studies have evaluated the impacts of the surrounding seascape on measures of habitat value beyond structural characteristics of fish communities (i.e., beyond fish abundance and community composition). The surrounding seascape can affect access to food resources or predators, possibly resulting in differences in habitat quality of focal habitat types at an individual level (i.e., in terms of condition or growth). For example, patchiness of temperate seagrass systems has been shown to affect growth of the bay scallop Argopecten irradians (Irlandi et al. 1995). In mangrove tidal 
creeks, habitat fragmentation results in decreased food availability and slower growth rates in Gray snapper (Lutjanus griseus) (Rypel \& Layman 2008). Animals that experience faster growth rates, or are in better condition, may experience decreased predation risk (Sogard 1997; Booth \& Hixon 1999; Booth \& Beretta 2004; Johnson 2008) or higher reproductive output (Hutchings 1993; Fox 1994; Slotte \& Fiksen 2000; Neff \& Cargnelli 2004). Therefore, understanding how the surrounding seascape affects individual-based measures of habitat quality, like condition or growth, may provide useful information regarding optimal fish habitat.

Effects of the seascape on individual-level traits and population-wide parameters can be combined to provide insight into overall ecosystem function. For example, secondary production, the accumulation of animal biomass over time, is a valuable measure of ecosystem function because it integrates density, growth, and survival into a single metric (Krebs 1994; Benke 2010). A previous study by Valentine-Rose et al. (2011) found that secondary production estimates may be the most informative variable for evaluating the effects of habitat fragmentation in tidal creek wetlands in The Bahamas. Irlandi (1995) found that spatial patterning of seagrass within the seascape determined the transfer of secondary production to higher trophic levels by affecting foraging success of invertebrate predators. Secondary production integrates multiple underlying processes and provides quantitative, functional information about effects of seascape on relative habitat values.

Grunts (Haemulidae) are common coral reef fishes that may be highly dependent on the attributes of the surrounding seascape because of their feeding strategy. Juveniles 
and adults of many species of grunts are known to shelter in structured habitats during the day (e.g., patch reefs, mangroves; (Starck \& Davis 1966; Ogden \& Ehrlich 1977; Verweij $\&$ Nagelkerken 2007). At dusk grunts have been observed to migrate into nearby soft bottom habitats (e.g., sand, seagrass) to feed (Starck \& Davis 1966; Ogden \& Ehrlich 1977; Robblee \& Zieman 1984; Burke 1995; Nagelkerken et al. 2000a). Through these daily foraging migrations, grunts link multiple habitat types over large spatial scales and represent important nutrient vectors to coral reef ecosystems (Meyer \& Schultz 1985). The nature of these habitat linkages may be dependent on the spatial juxtaposition of resting and foraging habitats (Nagelkerken et al. 2008). As a result, access to preferred, nocturnal foraging grounds within the seascape has the potential to affect the quality and function of focal habitats for grunts.

My overall objective was to identify how the seascape surrounding artificial reefs affects their relative value as habitat. By using experimental patch reef units, I controlled for patch habitat size and quality, so any differences among sites were expected to be a function of aspects of the surrounding seascape. I evaluated whether the amount of seagrass within the seascape surrounding these artificial patch reefs affected various measures of grunt habitat quality measured at the individual level (condition and growth), the population level (abundance), and the ecosystem function level (secondary production). Specifically, I expected that increased cover of seagrass in the seascape surrounding artificial reefs would result in better fish condition, faster growth rates, increased fish abundance, and increased secondary production of White grunts than on reefs in seascapes with lower cover of seagrass. 


\section{MATERIALS AND METHODS}

Study area. The study was conducted in the Bight of Old Robinson, Abaco, Bahamas (Fig. 3.1). The Bight of Old Robinson is a semi-enclosed bay that has a complex benthic mosaic comprised of sand, seagrass, hard-bottom and patch reef habitat, as well as tidal creeks with mangrove-lined shorelines. The depth of the Bight ranges from $<1$ to 4 meters. I used a series nine of artificial patch reefs created in March 2009 within the Bight to test the importance of seascape factors on reef fish communities (Yeager et al. 2011). Forty concrete cinder blocks were used to create each artificial reef (reef dimensions: $122 \mathrm{~cm} \mathrm{~L} \mathrm{x} 76 \mathrm{~cm} \mathrm{H} \mathrm{x} 81 \mathrm{~cm} \mathrm{D,} \mathrm{Fig} 1 \mathrm{c})$. Benthic habitats surrounding the reefs were composed of sandy bottom and Thalassia testudinum-dominated seagrass beds. Artificial reefs were located at least $500 \mathrm{~m}$ from natural patch reefs.

The percent cover of seagrass within the study area was mapped in August 2009. These maps were generated from estimates of percent cover within 1-m ${ }^{2}$ quadrats at 609 haphazardly selected points within the study area. The distribution of seagrass around the

reefs was mapped using the measured percent cover of seagrass at these fixed points and interpolating these coverages to a $31,000 \mathrm{~m}^{2}$ area (circle with $100 \mathrm{~m}$ radius) around each reef with an Inverse Distance Weighted Interpolation in ArcGIS (Lirman \& Cropper 2003). 
Study Species. In this study, I focused on White grunt (Haemulon plumierii), one of the most important species driving differences in community structure on the experimental reefs across the seascape gradient (Yeager et al. 2011). Juvenile White grunts are known to form large, daytime, resting schools on patch reef habitats and show high site fidelity for periods of months (Ogden \& Ehrlich 1977; Helfman et al. 1982; Appeldoorn et al. 1997; Appeldoorn et al. 2009). At dusk, individuals of these schools make repeated nightly migrations into surrounding soft bottoms habitat (Ogden \& Ehrlich 1977; Helfman et al. 1982; Appeldoorn et al. 2009), queued by decreased light levels after sunset (McFarland et al. 1979). Once in the soft-bottom habitat, these schools begin to spread out and solitary individuals feed within a small area throughout the night (Ogden \& Ehrlich 1977; Helfman et al. 1982; Robblee \& Zieman 1984; Burke 1995). Juvenile White grunts may migrate up to $300 \mathrm{~m}$ from their diurnal resting habitat, although many individuals may stay within $100 \mathrm{~m}$ of the reef if seagrass beds are in close proximity (Ogden \& Ehrlich 1977; Burke 1995; Appeldoorn et al. 2009). Prior to sunrise, these schools re-aggregate and return to the same reef, where they spend the day primarily inactive (Ogden \& Ehrlich 1977; McFarland et al. 1979; Appeldoorn et al. 2009). White grunts feed mainly on benthic invertebrates (Randall 1967; Appeldoorn et al. 1997; Appeldoorn et al. 2009; Clark et al. 2009) and seagrass habitats are known to support increased densities of benthic invertebrates when compared to unvegetated bottom (Orth et al. 1984; Ansari et al. 1991; Heck et al. 1997; Nakamura \& Sano 2005). Furthermore, previous studies have reported observations of White grunts feeding in seagrass habitat, as opposed to unvegetated bottom, during their nightly foraging migrations (Ogden \& Zieman 1977; Appeldoorn et al. 1997). 
Data collection. The cover of seagrass within the seascape was evaluated within $100 \mathrm{~m}$ of each artificial reef. The mean percent cover derived from previous seagrass mapping was calculated in ArcGIS (ERSI 2008). Previous studies have found that congeneric species of grunts ( $H$. flavolineatum and $H$. scirus) respond most strongly to the seascape within $100 \mathrm{~m}$ of their daytime resting habitats (Kendall et al. 2003; Pittman et al. 2007a). Furthermore, differences in seagrass cover at this scale were previously found to be a better predictor of fish community structure on this artificial reef array than seagrass cover at smaller scales (4 m, $50 \mathrm{~m}$, Yeager et al. 2011).

In order to support the assumption that seagrass density may affect food availability for White grunts, benthic cores were used to evaluate the abundance of White grunt prey items at sites with varying seagrass densities. These sites were located at least $100 \mathrm{~m}$ away from natural or artificial reefs, but within the general study area, and were used to examine natural densities of invertebrates in the absence of significant predation from reef-associated predators. The percent cover of seagrass within $18-1 \mathrm{~m}^{2}$ quadrats was estimated using a modified Braun-Blanquet method (Fourqurean et al. 2001). The benthos from each quadrat was subsampled using $10-\mathrm{cm}$ diameter core to collect the top $3 \mathrm{~cm}$ of sediment. Sediment samples were with stained with Rose Bengal to aid in the location of benthic organisms. In the laboratory, benthic sediment samples were sifted using $2 \mathrm{~mm}$ and $500 \mu \mathrm{m}$ sieves. Sieved samples were sorted under a dissecting microscope. All organisms enumerated were identified to the lowest feasible taxonomic level. 
The abundance of White grunts on artificial reefs was estimated using underwater visual census by trained observers (LAY and CAL). Sizes of all fish were estimated to the nearest $\mathrm{cm}$ total length with the aid of a graduated dive slate. Fish communities were surveyed on 15 dates from March 2009 to April 2010 (see Yeager et al. [2011] for more details on fish surveys). I restricted all my analyses to juvenile White grunts $<15 \mathrm{~cm} \mathrm{SL}$ $(<19 \mathrm{~cm} \mathrm{TL})$ in an attempt to include only juveniles that had settled on the reefs, and not larger individuals that may have migrated from other habitats. Only 15 individuals, representing less $1 \%$ of all individuals observed during the study period, were excluded using this criterion.

Measures of fish condition and growth rate were used to evaluate individual-level measures of habitat quality. Fish condition was evaluated using the morphometric relative condition factor (Le Cren 1951). Fish which are heavier than average for their length may be considered to be in better condition than fish that are lighter than average. To estimate growth rate, I used the ratio of RNA to DNA in muscle tissue. Examination of RNA:DNA content to investigate growth rate is based on the fact that the amount of DNA in cells remains constant, while the amount of RNA increases with growth rate as more protein synthesis is required. This technique has been used successfully as a measure of relative growth in fishes (Buckley 1984; Folkvord et al. 1996; Garcia et al. 1998; Buckley et al. 1999) and has been shown to typically integrate growth rates over a period of weeks (Johnson et al. 2002; Piazza \& La Peyre 2010).

White grunts were collected from artificial reefs using mesh wire traps with mesh sizes of 1 and $2 \mathrm{~cm}$ in April 2010. Traps were deployed in the benthos surrounding the 
artificial reefs and were allowed to soak for 2-14 $\mathrm{h}$ before being retrieved. White grunts were removed from the traps and placed into coolers of fresh ocean water with aerators before being transferred by boat to land to be processed. Fish were euthanized with an overdose of eugenol, a known fish anesthetic (following Florida International University IACUC \# A3096-01, 10-013). White grunts were euthanatized individually to ensure tissues were promptly preserved to prevent degradation of RNA. The standard length (SL) of each fish was measured to the nearest $\mathrm{mm}$ and blotted wet weight was measured to the nearest $0.01 \mathrm{~g}$. A small muscle tissue sample was removed and placed into a $1.5 \mathrm{~mL}$ microcentrifuge tube filled with RNAlater to prevent degradation of RNA, then kept frozen $\left(-20^{\circ} \mathrm{C}\right)$ until further processing.

Fish muscle samples were processed for RNA and DNA concentrations in the laboratory at Florida International University following a protocol modified from Bolnick and Lau (2008). My protocol differed only slightly from Bolnick and Lau (2008); White grunt muscle tissue used weighed between $2-8 \mathrm{mg}$ and a homogenized sample of mosquitofish (Gambusia affinis) was used for the control homogenate.

Data analysis. The relationship between the cover of seagrass and the density of benthic invertebrates in core samples was examined using linear regression. Benthic invertebrate densities were fourth-root transformed prior to analysis in to meet assumptions of normality $(P=0.1)$ and homogeneity of variances $(P=0.2)$. 
Fish length and weight were used to calculate the predicted length-weight relationship for White grunts in this system. The relationship between fish length and weight was modeled with the following equation:

$$
\mathrm{W}=\mathrm{aL}^{\mathrm{n}} \quad \text { (Equation 1) }
$$

where $\mathrm{W}=$ the weight in $\mathrm{g}, \mathrm{L}=$ fish standard length in $\mathrm{mm}$ and $\mathrm{a}$ and $\mathrm{n}$ are constants. Relative condition factor can be calculated using this empirically derived length-weight relationship as follows:

$$
\mathrm{K}_{\mathrm{n}}=\frac{\mathrm{w}}{\mathrm{aL}^{\mathrm{n}}} \quad \text { (Equation 2) }
$$

(Le Cren 1951). When $K_{n}>1$ means a fish is heavier than expected on the basis of its size (i.e., higher condition) and $\mathrm{K}_{\mathrm{n}}<1$ indicates an individual is lighter than expected for its size (i.e., lower condition). The mean relative condition factor was calculated for each reef. The RNA:DNA ratios were first corrected for fish length and sample run using linear regression procedures (Sokal \& Rohlf 1981) before the mean of corrected RNA:DNA ratios were calculated for each reef.

I focused the analysis of grunt abundance on artificial reefs over the time period after which fish communities had become relatively stable (i.e., fish abundance, species richness and community structure changed little over time, Yeager et al. 2011). The mean number of grunts from July 2009-April 2010 on each reef was calculated.

Secondary production was calculated as the accumulation of new biomass over time (Benke 2010). Growth rates were estimated by following some cohorts for periods 
of months to find a mean linear growth rate $(\mathrm{G})$ of $0.03 \mathrm{~cm} /$ day, which was within the range of growth rates reported for juvenile French grunts (Grol et al. 2008). A linear growth rate was used to model fish growth as opposed to an exponential growth model (e.g., von Bertalanffy growth equation [von Bertalanffy 1938]), as the former is more appropriate for modeling growth of juvenile fishes (Faunce \& Serafy 2008a). Production estimates were calculated for each individual size class $(1 \mathrm{~cm})$ for each survey interval using a modified version of the removal-summation method (Waters \& Crawford 1973; Benke 1976). Secondary production $\left(\mathrm{g} \mathrm{WW}^{*} \mathrm{t}^{-1}\right)$ was calculated as:

$$
\operatorname{Ps}(\Delta \mathrm{t})=(\overline{\mathrm{B}} \mathrm{s}(\mathrm{t}+1)-\overline{\mathrm{B}} \mathrm{s}(\mathrm{t})) * \overline{\mathrm{N}} \mathrm{s}(\Delta \mathrm{t}) \quad \text { (Equation 3) }
$$

where $\operatorname{Ps}_{(\Delta t)}$ is the production of individuals belonging to size class $s$ from the start to the end of time interval $t$. The time interval $t$ varied based on the number of days between surveys. $\overline{\mathrm{B}} \mathrm{s}(\mathrm{t})$ represented the average biomass for an individual from size class $\mathrm{s}$ at the beginning of the time interval t. Biomass (B) was calculated based on measured lengthweight relationship $(\log \mathrm{W}=3.10 * \log \mathrm{L}-4.75, \mathrm{~W}=$ weight in $\mathrm{g}$ and $\mathrm{L}=$ standard length in $\mathrm{mm}, \mathrm{R}^{2}=0.99$ ). The total length of an individual from size class $\mathrm{s}$ at the end of the time interval $t$ was estimated using the linear growth rate $(G)$. The $\bar{B} s_{(t+1)}$ was then calculated using the estimated total length at the end of the $t$ and length-weight relationship as described above. $\overline{\mathrm{N}} \mathrm{s}_{(\Delta \mathrm{t})}$ is the mean number of individuals in the size class over the time interval. I summed my secondary production estimates across all size classes between 0 and $19 \mathrm{~cm}$ TL (corresponding to 0 to $15 \mathrm{~cm} \mathrm{SL)} \mathrm{from} \mathrm{July} 2009$ to April 2010 to estimate total secondary production per reef over the study period. 
The relationship between individual- (condition and RNA:DNA), population(abundance) and functional- (secondary production) derived estimates of habitat quality and the mean percent cover of seagrass within $100 \mathrm{~m}$ of each reef were tested with separate linear regression models (SAS software v 9.2).

\section{RESULTS}

Percent cover of seagrass at patch habitats from which benthic cores were sampled ranged from 0-90\%. Major taxonomic groupings of invertebrate taxa from benthic cores included (ordered from most to least abundant): Gastropoda (33.3\%), Annelida (24.7\%), Ostracoda (13.6\%), unidentified worms (9.3\%), Bivalvia (13.6\%), Copepoda (6.2\%), Ophiuroidea (1.9\%), Tanaidacea (1.2\%) and Decopoda, Mysidacea, and unidentified Crustacea making up less than $1 \%$, each, of the total benthic invertebrate abundance. The abundance of benthic invertebrates ranged from 1 to 25 individuals per core (corresponding to density of 1.3 to 31.8 individuals $/ 100 \mathrm{~cm}^{2}$ ). The density of benthic invertebrates (fourth-root transformed) was positively related to the percent cover of seagrass $\left(\mathrm{y}=1.58+0.0052 \mathrm{x}, \mathrm{r}^{2}=0.24, P=0.04\right.$, Fig. 3.2).

The mean percent cover of seagrass within $100 \mathrm{~m}$ of the artificial reefs ranged from $16.4 \%$ to $49.3 \%$. A total of 221 individual White grunts ranging from $4.1-14.9$ $\mathrm{cm}$ SL were examined for individual-based measures of habitat quality (relative condition factor and RNA:DNA ratios). Relative condition factor $\left(\mathrm{K}_{\mathrm{n}}\right)$ ranged from 0.58 to 1.21 
and mean $( \pm \mathrm{SE})$ relative condition factor ranged from $0.91 \pm 0.02$ to $1.07 \pm 0.01$ among reefs. The mean relative condition factor was not related to the mean percent cover of seagrass within $100 \mathrm{~m}\left(\mathrm{r}^{2}=0.04, P=0.6\right.$, Fig. 3.3a). Corrected RNA:DNA ranged from 0.29 to 2.76 among individuals and mean ( \pm SE) RNA:DNA ranged from $1.12 \pm 0.11$ to $1.44 \pm 0.06$ among reefs. Like relative condition factor, the mean RNA:DNA was not related to the mean percent cover of seagrass within $100 \mathrm{~m}\left(\mathrm{r}^{2}=0.06, P=0.5\right.$, Fig. $\left.3.3 \mathrm{~b}\right)$.

The mean number $( \pm$ SE) of White grunts per reef from July 2009-April 2010 ranged from $6.7 \pm 1.1$ to $104.6 \pm 27.6$ individuals/reef. The mean number of grunts per reef was positively related to the mean percent cover of seagrass within $100 \mathrm{~m}\left(\mathrm{r}^{2}=0.64\right.$, $P=0.007$, Fig. 3.3c). White grunt secondary production ranged from 135 to $2246 \mathrm{~g}$ wet weight per reef per year. Secondary production was positively related to the mean percent cover of seagrass within $100 \mathrm{~m}\left(\mathrm{r}^{2}=0.48, P=0.04\right.$, Fig. $\left.3.3 \mathrm{~d}\right)$.

\section{DISCUSSION}

My experiment, employing a set of artificial reefs, provided clear evidence that seascape context affects aspects of habitat quality and ecosystem function. However, seascape effects on habitat quality for White grunts appeared to be limited to populationlevel and functional responses; increased cover of seagrass within the seascape resulted in higher abundance of White grunts on reefs and increased secondary production. In contrast, I did not find any relationship between seascape context and individual-based 
traits. Combining measures of individual fitness with population and functional measures may reveal a more complex view of the relationship between organisms and the seascape.

Increased cover of seagrass within the seascape likely provides grunts with higher quality foraging habitat by increasing prey availability. While I did not map prey availability around the reefs explicitly, my benthic core sampling results support the hypothesis that seagrass represents higher quality foraging habitat, as densities of benthic invertebrates increased with seagrass cover. Reports from previous studies of White grunts feeding preferential in seagrass at night, as opposed to sandy bottom (Ogden and Zieman 1977, Appeldoorn et al. 1997), are likely a result of increased resource availability. Additionally, seagrass may provide increased shelter from predators when compared to sandy bottom, affording grunts with lower predation risk during their foraging bouts. Increased prey availability and structural complexity associated with this habitat likely explain the positive effects of seagrass availability within the seascape on White grunt habitat quality observed within this study.

While there was not a clear relationship between seascape context and individualbased measures of habitat quality, more grunts were found on artificial reefs in seascapes with higher seagrass cover than on reefs in seascapes with lower seagrass cover. This pattern could be explained in part by an ideal free distribution model, where individuals distribute themselves proportionally to the suitability (e.g., resource availability) of various habitat patches (Fretwell \& Lucas 1970). Under this scenario, all habitat patches are similar in terms of suitability at the individual level because the ratio of consumers to resources is similar across patches. In this study, reefs with more seagrass in the seascape 
likely represent the most suitable foraging habitat, mediated in at least part through increased availability of grunt prey items, causing more grunts to utilize those reefs in close proximity to preferred foraging areas. However, increased abundance of grunts on reefs with more seagrass may have led to greater competition for prey, making per capita resource availability similar across reefs. As a result, reefs in different seascape contexts may represent similar habitat quality at an individual-level; the benefit of increased resource availability associated with higher seagrass seascapes appeared to be manifest only at the population level in my study.

These population-level differences in abundance led to increased secondary production on reefs within seascapes with more seagrass. Because growth rates were assumed to be similar across reefs, differences in secondary production were driven by differences in fish abundance and size structure through time, as opposed to differences in growth rates. If my assumption of similar growth rates was not reasonable, this could have affected trends in secondary production. However, I did not find a trend between my proxy for growth (RNA:DNA) and seascape context in this study. Furthermore, it has been suggested that differences in secondary production among sites is likely driven by fish abundance and size structure when these metrics vary greatly among sites, as opposed to small differences in growth (Rypel \& Layman 2008; Valentine-Rose \& Layman 2011; Valentine-Rose et al. 2011). Increased fish secondary production on reefs with more seagrass within the seascape likely translates to an increased contribution to the adult population, as well as increased transfer of energy to higher trophic levels 
through predation (Randall 1967). For this reason, secondary production may be a useful tool to evaluate effects of seascape context on habitat quality.

While artificial reefs have been found to be good experimental representations of natural patch reef habitats (Alevizon et al. 1985; Hixon \& Beets 1989, 1993; Yeager et al. 2011), there are a few limitations that should be considered when applying the results of this study to natural systems. First, reefs in this study were relatively small compared to many natural patch reefs. The additional structure provided by larger reefs would likely support more individuals, potentially resulting in increased interspecific competition for resources. Also, the close proximity of some reefs may lead to overlap in nighttime foraging areas, although the mean overlap was only $14 \%$ (range $0 \%-29 \%$ ) of a seascape area of $31,000 \mathrm{~m}^{2}$. Furthermore, in this study, individual-based measures of habit quality (condition and RNA:DNA) were assessed only once, providing a snap-shot of these metrics. Yet, this single sampling event was necessary to avoid affecting grunt assemblages during the course study. How these measures vary temporally is unknown. Finally, while not my objective, it was not possible to definitively differentiate between "new" secondary production of White grunts versus attraction of fish from surrounding habitat. However, I observed continual recruitment of the fish to these reefs as early juveniles (1-2 cm in size) and the artificial reefs were relatively isolated from natural, structured habitats (at least $500 \mathrm{~m}$ away from the nearest natural reef) from which larger grunts could have moved. Moreover, a previous study found that juvenile grunts are not recruitment limited and availability of post-settlement, structured habitat appears to control population sizes (Shulman \& Ogden 1987). These factors support the notion that 
secondary production of juvenile White grunts associated with these artificial reefs likely represents new production.

Results of my study highlight the importance of considering higher-order response variables when attempting to evaluate habitat quality. Data needed to evaluate the importance nursery areas for marine species are typically divided into hierarchical levels: (1) presence/absence, (2) density, (3) growth or predation risk, and (4) production (Able et al. 1999; Beck et al. 2001; Dahlgren et al. 2006). Examinations of habitat quality defined by individual traits in isolation may lead to inaccurate estimates of habitat value, if density dependence, selective mortality and connectivity are not considered (Searcy 2007). Higher order estimates of habitat quality, such as production, are often considered to be the most rigorous estimators and integrate across other metrics (Searcy 2007; Faunce \& Serafy 2008a; Valentine-Rose et al. 2011). In this study, if I had focused on metrics of growth and condition alone, I would have failed to detect differences in habitat quality. Incorporation of abundance and secondary production provided for a more complete view of habitat quality for White grunt populations.

Integrating habitat variables across ecologically-relevant scales is critical for effective conservation and management programs (Mumby 2006; Sheaves 2009; Edwards et al. 2011). Incorporating various individual- and population-based measures of habitat value is crucial in advancing my understanding of the importance of seascape characteristics in determining the suitability of focal habitat types for populations of marine organisms. Populations of fisheries species, such as White grunts, may suffer multiple threats, including loss/alteration of habitat, and overharvest. Results of this study 
support the notion that even relatively minor changes in the surrounding seascape have the potential to affect ecosystems function (i.e., secondary production). Since reefs with more seagrass in the surrounding seascape support greater production of White grunts, a loss of seagrass cover could result in overall declines in production in such systems.

Acknowledgements. This project was funded by a National Science Foundation Graduate Research Fellowship and a Florida International University Presidential Fellowship to LAY, as well as National Science Foundation OCE \#0746164 to CAL. I thank Friends of the Environment, D. Haines, F. DeRosa and K. Rennirt on Abaco for their logistical support and the Department of Marine Resources of The Bahamas for research permits. Field assistance and help with data management was provided by J. Allgeier, A. Anton, D. Chacin, G. Mineau, L. Pierre, M. Seese, M. Simpson and E. Stoner. I thank four anonymous reviews for their comments which helped improve the manuscript. 


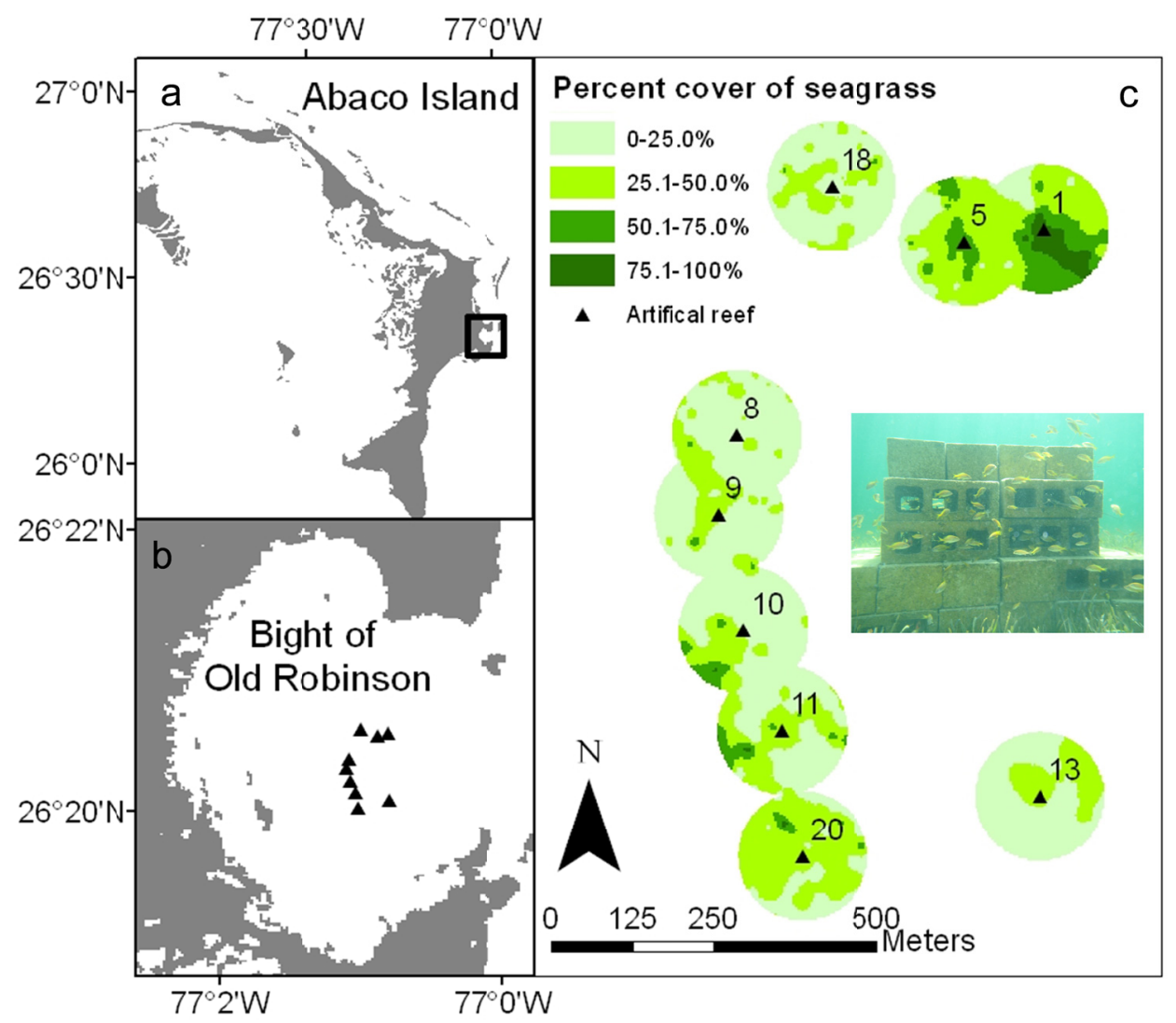

Fig. 3.1 Map of the study location and artificial reef sites. Panel c.) includes a map of the cover of seagrass within the seascape for each reef. Inset photo shows an artificial reef with a fish assemblage dominated by White grunts. 


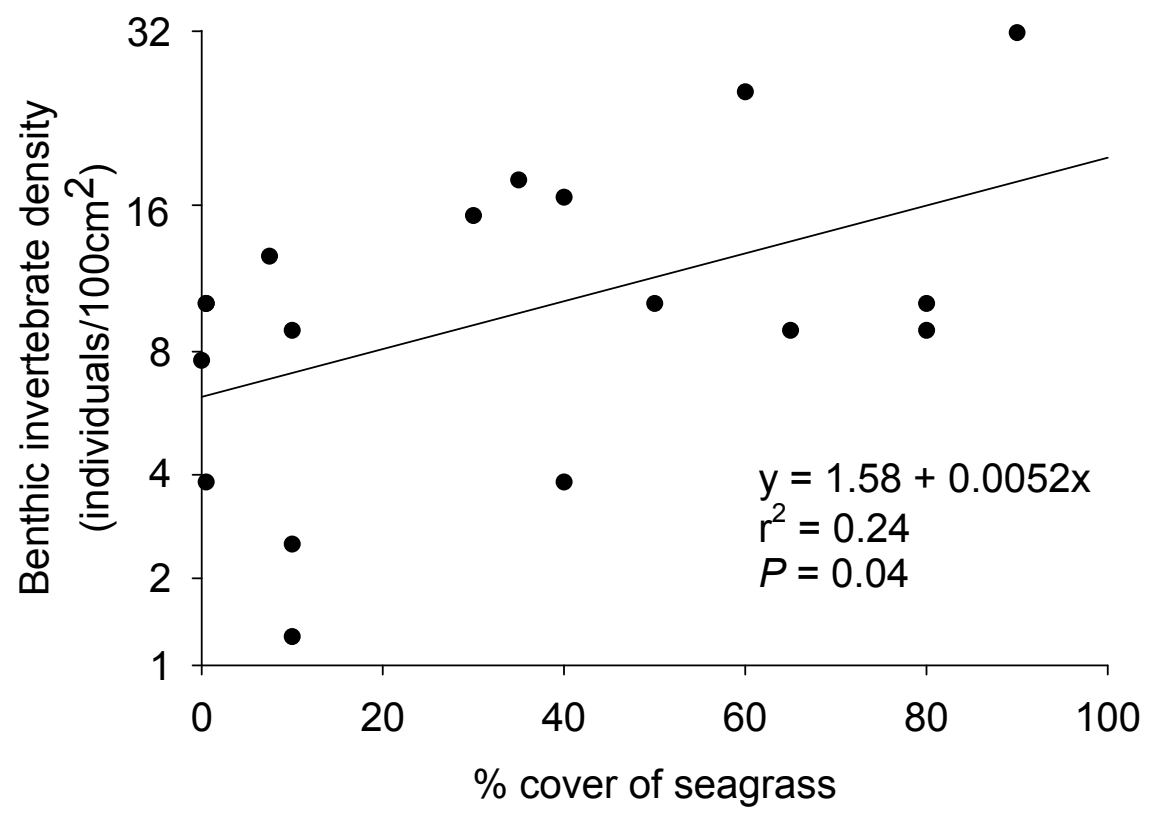

Fig. 3.2 Density of benthic invertebrates versus the percent cover of seagrass for benthic cores. Note that the density of benthic invertebrates is plotted on a fourth-root scale, but axis labels represent untransformed densities. 

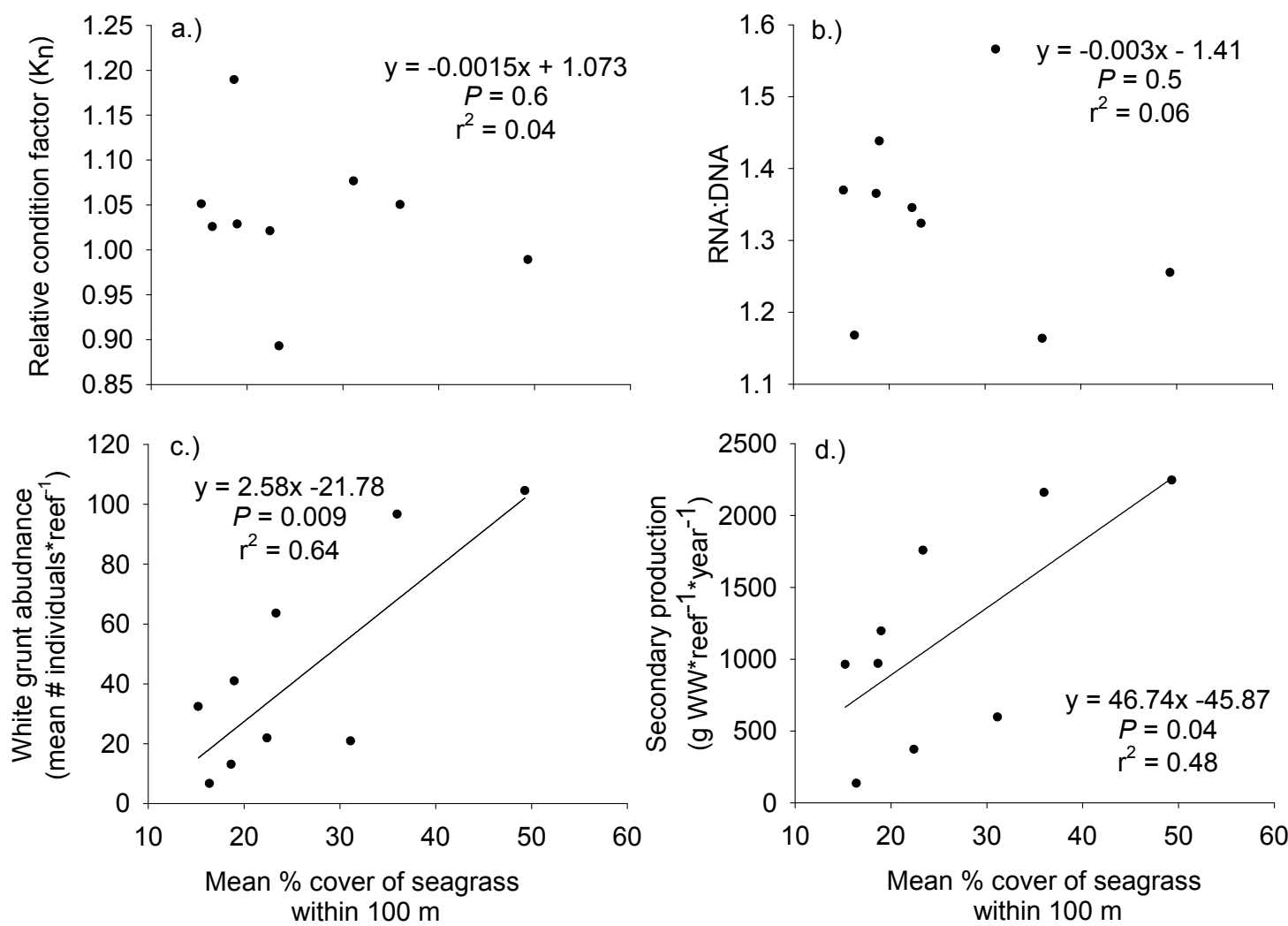

Fig. 3.3 Relationship between the mean percent cover of seagrass within the seascape and (a) mean relative condition factor, (b) mean RNA:DNA, (c) abundance, and (d) secondary production of White grunts. A trend line is shown for the relationships where $P<0.05$. 


\section{LITERATURE CITED}

Able KW, Manderson JP, Studholme AL (1999) Habitat quality for shallow water fishes in an urban estuary: the effects of man-made structures on growth. Mar Ecol Prog Ser 187:227-235

Alevizon WS, Gorham JC, Richardson R, Mccarthy SA (1985) Use of Man-Made Reefs to Concentrate Snapper (Lutjanidae) and Grunts (Haemulidae) in Bahamian Waters. Bull Mar Sci 37:3-10

Ansari ZA, Rivonker CU, Ramani P, Parulekar AH (1991) Seagrass Habitat Complexity and Macroinvertebrate Abundance in Lakshadweep Coral-Reef Lagoons, Arabian Sea. Coral Reefs 10:127-131

Appeldoorn RS, Aguilar-Perera A, Bouwmeester BLK, Dennis GD, Hill RL, Merten W, Recksiek CW, Williams SJ (2009) Movement of fishes (Grunts: Haemulidae) across the coral reef seascape: A review of scales, patterns and processes. Caribb J Sci 45:304-316

Appeldoorn RS, Recksiek CW, Hill RL, Pagan FE, Dennis GD (1997) Marine protected areas and reef fish movements: the role of habitat in controlling ontogenetic migration. Proceedings of the 8th International Coral Reef Symposium 2:19171922

Beck M, Heck Jr. K, Able K, Childers D, Eggleston D, Gillanders B, Halpern B, Hays C, Hoshino K, Minello T, Orth R, Sheridan P, Weinstein M (2001) The identification, conservation, and management of estuarine and marine nurseries for fish and invertebrates. Bioscience 51:633-641

Benke A (1976) Dragonfly production and prey turnover. Ecology 57:915-927

Benke A (2010) Secondary Production. Nature Education Knowledge 1:5

Bolnick DI, Lau OL (2008) Predictable patterns of disruptive selection in stickleback in postglacial lakes. Am Nat 172:1-11

Booth DJ, Beretta GA (2004) Influence of recruit condition on food competition and predation risk in a coral reef fish. Oecologia 140:289-294

Booth DJ, Hixon MA (1999) Food ration and condition affect early survival of the coral reef damselfish, Stegastes partitus. Oecologia 121:364-368

Buckley L, Caldarone E, Ong TL (1999) RNA-DNA ratio and other nucleic acid-based indicators for growth and condition of marine fishes. Hydrobiologia 401:265-277

Buckley LJ (1984) RNA-DNA ratio: an index of larvale fish growth in the sea. Mar Biol 80:291-298 
Burke NC (1995) Nocturnal Foraging Habitats of French and Bluestriped Grunts, Haemulon flavolineatum and H. sciurus, at Tobacco Caye, Belize. Environ Biol Fishes 42:365-374

Clark RD, Pittman S, Caldow C, Christensen J, Roque B, Appeldoorn RS, Monaco ME (2009) Nocturnal fish movement and trophic flow across habitat boundaries in a coral reef ecosystem (SW Puerto Rico). Caribb J Sci 45:282-303

Dahlgren CP, Kellison GT, Adams AJ, Gillanders BM, Kendall MS, Layman CA, Ley JA, Nagelkerken I, Serafy JE (2006) Marine nurseries and effective juvenile habitats: concepts and applications. Mar Ecol Prog Ser 312:291-295

Edwards HJ, Elliott IA, Pressey RL, Mumby PJ (2011) Incorporating ontogenetic dispersal, ecological processes and conservation zoning into reserve design. Biol Conserv 143:457-470

ERSI (2008) ArcGIS v9, Redlands, CA USA

Faunce CH, Serafy JE (2008) Growth and secondary production of an eventual reef fish during mangrove residency. Estuar Coast Shelf Sci 79:93-100

Folkvord A, Ystanes L, Johannessen A, Moksness E (1996) RNA:DNA ratios and growth of herring (Clupea harengus) larvae reared in mesocosms. Mar Biol 126:591-602

Fourqurean JW, Willsie A, Rose CD, Rutten LM (2001) Spatial and temporal pattern in seagrass community composition and productivity in south Florida. Mar Biol $138: 341-354$

Fox MG (1994) Growth, Density, and Interspecific Influences on Pumpkinseed Sunfish Life-Histories. Ecology 75:1157-1171

Fretwell SD, Lucas HL (1970) On territorial behaviour and other factors influencing habitat distribtution in birds. Acta biotheroretica 19:16-36

Garcia A, Cortes D, Ramirez T (1998) Daily larval growth and RNA and DNA content of the NW Mediterranean anchovy Engraulis encrasicolus and their relations to the environment. Mar Ecol Prog Ser 166:237-245

Grabowski JH, Hughes AR, Kimbro DL, Dolan MA (2005) How habitat setting influences restored oyster reef communities. Ecology 86:1926-1935

Grober-Dunsmore R, Frazer TK, Beets JP, Lindberg WJ, Zwick P, Funicelli NA (2008) Influence of landscape structure on reef fish assemblages. Landsc Ecol 23:37-53

Grober-Dunsmore R, Pittman SJ, Caldow C, Kendall MS, Frazer TK (2009) A landscape ecology approach for the study of ecological connectivity across tropical marine seascapes. In: Nagelkerken I (ed) Ecological Connectivity among Tropical Coastal Ecosystems. Springer, p 493-530 
Grol M, Dorenbosch M, Kokkelmans E, Nagelkerken I (2008) Mangrvoes and seagrass beds do not enhance growth of early juveniles of a coral reef fish. Mar Ecol Prog Ser 366:137-146

Heck KL, Jr., Nadeau DA, Thomas R (1997) The nursery role of seagrass beds. Gulf Mex Sci 1:50-54

Helfman GS, Meyer JL, McFarland WN (1982) The ontogeny of twilight migration patterns in grunts (Pisces, Haemulidae). Anim Behav 30:317-326

Hixon MA, Beets JP (1989) Shelter Characteristics and Caribbean Fish Assemblages Experiments with Artificial Reefs. Bull Mar Sci 44:666-680

Hixon MA, Beets JP (1993) Predation, prey refuges, and the strucuture of coral-reef fish assemblages. Ecol Monogr 63:77-101

Hovel KA, Lipcius RN (2001) Habitat fragmentation in a seagrass landscape: Patch size and complexity control blue crab survival. Ecology 82:1814-1829

Hutchings JA (1993) Adaptive life histories effected by age-specific survival and growth rate. Ecology 74:673-684

Irlandi EA, Ambrose WG, Orlando BA (1995) Landscape Ecology and the MarineEnvironment - How Spatial Configuration of Seagrass Habitat Influences Growth and Survival of the Bay Scallop. Oikos 72:307-313

Johnson DW (2008) Combined effects of condition and density on post-settlement survival and growth of a marine fish. Oecologia 155:43-52

Johnson MW, Rooker JR, Gatlin DM, Holt GJ (2002) Effects of variable ration levels on direct and indirect measures of growth in juvenile red drum (Sciaenops ocellatus). J Exp Mar Biol Ecol 274:141-157

Kendall MS, Christensen JD, Hillis-Starr Z (2003) Multi-scale data used to analyze the spatial distribution of French grunts, Haemulon flavolineatum, relative to hard and soft bottom in a benthic landscape. Environ Biol Fishes 66:19-26

Krebs C (1994) Ecosystem metabolism II: secondary production. In: Krebs C (ed) Ecology: the experimental analysis of distribution and abundance. Benjamin Cummings, New York, USA, p 633-658

Le Cren E (1951) The length-weight relationship and seasonal cycle in gonad weight and condition in the perch (Perca fluviatulis). J Anim Ecol 20:201-219

Lirman D, Cropper WP, Jr. (2003) The influence of salinity on seagrass growth, survivorship and distribution within Biscayne Bay, Florida: field, experimental and modeling studies. Estuaries 26:131-141 
McFarland W, Ogden JC, Lyth J (1979) The influence of light on the twilight migrations of grunts. Environ Biol Fishes 4:9-22

Meyer JL, Schultz ET (1985) Migrating Haemulid Fishes as a Source of Nutrients and Organic-Matter on Coral Reefs. Limnol Oceanogr 30:146-156

Mumby PJ (2006) Connectivity of reef fish between mangroves and coral reefs: Algorithms for the design of marine reserves at seascape scales. Biol Conserv $128: 215-222$

Nagelkerken I, Bothwell J, Nemeth RS, Pitt JM, van der Velde G (2008) Interlinkage between Caribbean coral reefs and seagrass beds through feeding migrations by grunts (Haemulidae) depends on habitat accessibility. Mar Ecol Prog Ser $368: 155-164$

Nagelkerken I, Dorenbosch M, Verberk WCEP, de la Moriniere EC, van der Velde G (2000) Day-night shifts of fishes between shallow-water biotopes of a Caribbean bay, with emphasis on the nocturnal feeding of Haemulidae and Lutjanidae. Mar Ecol Prog Ser 194:55-64

Nakamura Y, Sano M (2005) Comparison of invertebrate abundance in a seagrass bed and adjacent coral and sand areas at Amitori Bay, Iriomote Island, Japan. Fish Sci $71: 543-550$

Neff BD, Cargnelli LM (2004) Relationships between condition factors, parasite load and paternity in bluegill sunfish, Lepomis macrochirus. Environ Biol Fishes 71:297304

Ogden JC, Ehrlich PR (1977) Behavior of Heterotypic Resting Schools of Juvenile Grunts (Pomadasyidae). Mar Biol 42:273-280

Ogden JC, Zieman JC (1977) Ecological aspects of coral reef-seagrass beds contacts in the Caribbean. Proceedings of the 3rd International Coral Reef Symposium

Orth RJ, Heck KL, Vanmontfrans J (1984) Faunal communities in seagrass beds: a review of the influence of plant structure and prey characteristics on predator-prey relationships. Estuaries 7:339-350

Piazza BP, La Peyre MK (2010) Using Gambusia affinis growth and condition to assess estuarine habitat quality: a comparison of indices. Mar Ecol Prog Ser 412:231-245

Pittman SJ, Caldow C, Hile SD, Monaco ME (2007a) Explaining patterns of abundance for fish using mangroves: A multi-scale seascape approach. Bull Mar Sci 80:930931

Pittman SJ, Caldow C, Hile SD, Monaco ME (2007b) Using seascape types to explain the spatial patterns of fish in the mangroves of SW Puerto Rico. Mar Ecol Prog Ser 348:273-284 
Randall JE (1967) Food habitat of reef fishes of the West Indies. Stud Trop Oceanogr $5: 665-847$

Robbins BD, Bell SS (1994) Seagrass Landscapes - a Terrestrial Approach to the Marine Subtidal Environment. Trends Ecol Evol 9:301-304

Robblee MB, Zieman JC (1984) Diel Variation in the Fish Fauna of a Tropical Seagrass Feeding Ground. Bull Mar Sci 34:335-345

Rypel AL, Layman CA (2008) Degree of aquatic ecosystem fragmentation predicts population characteristics of gray snapper (Lutjanus griseus) in Caribbean tidal creeks. Can J Fish Aquat Sci 65:335-339

Searcy SP, Eggleston, D.B., and Hare, J.A. (2007) Is growth a reliable indicator of habitat quality and essential fish habitat for juvenile estuarine fish? Can J Fish Aquat Sci 64:681-691

Sheaves M (2009) Consequences of ecological connectivity: the coastal ecosystem mosaic. Mar Ecol Prog Ser 391:107-115

Sheaves M, Johnston R (2009) Ecological drivers of spatial variability among fish fauna of 21 tropical Australian estuaries. Mar Ecol Prog Ser 385:245-260

Shulman MJ, Ogden JC (1987) What controls tropical reef fish populations: recruitment or bethic mortality? An example in the Caribbean reef fish Haemulon flavolineatum Mar Ecol Prog Ser 39:233-242

Slotte A, Fiksen O (2000) State-dependent spawning migration in Norwegian springspawning herring. J Fish Biol 56:138-162

Sogard SM (1997) Size-selective mortality in the juvenile stage of teleost fishes: A review. Bull Mar Sci 60:1129-1157

Sokal RR, Rohlf FJ (1981) Biometry: The priciples and practice of statistics in biological reserach, Vol. W.H. Freeman and Company, New York, USA

Starck WA, Davis WP (1966) Night habits of fishes of Alligator Reef, Florida. Ichthyologica 38:313-356

Turner MG (1989) Landscape Ecology - the Effect of Pattern on Process. Annu Rev Ecol Syst 20:171-197

Turner MG (2005) Landscape ecology in North America: Past, present, and future. Ecology 86:1967-1974

Valentine-Rose L, Layman CA (2011) Response of fish assemblage structure and function following restoration of two small Bahamian tidal creeks. Restor Ecol $19: 205-215$ 
Valentine-Rose L, Rypel AL, Layman CA (2011) Community secondary production as a composite measure for examining effects of aquatic ecosystem fragmentation. Bull Mar Sci 87:913-937

Verweij MC, Nagelkerken I (2007) Short and long-term movement and site fidelity of juvenile Haemulidae in back-reef habitats of a Caribbean embayment. Hydrobiologia 592:257-270

von Bertalanffy L (1938) A quantitative theory of organic growth. Hum Biol 10:181-213

Waters TF, Crawford GW (1973) Annual production of a stream matfly population: a comparison of methods. Limnol Oceanogr 18:286-296

Yeager LA, Layman CA, Allgeier JE (2011) Effects of habitat heterogeneity at multiple spatial scales on fish community assembly. Oecologia 167:157-168 


\section{CHAPTER IV}

QUANTITY FOR QUALITY: FORAGING TRADE-OFFS FOR A GENERALIST FISH PREDATOR ACROSS AN ENVIRONMENTAL GRADIENT 
Abstract:

Human alteration of natural landscapes often results in species-poor communities dominated by resilient, generalist species. A foraging trade-off may be one mechanism by which generalists remain successful in degraded environments. I examined diet, prey quality, growth, and condition for a generalist fish predator, Gray snapper (Lutjanus griseus), at five sites across an estuarine gradient in the Loxahatchee River estuary, Florida. Snapper diets shifted from dominance by low quality, intertidal crabs upstream to an increased reliance on higher quality shrimp, fishes, and benthic crabs downstream. Concurrently, the frequency and volume of food in snapper stomachs decreased moving downstream. Measures of snapper growth and condition did not vary among sites. Results suggest fish compensate for lower quality prey upstream by eating more, and thus individuals are able to maintain a similar level of fitness across the environmental gradient in the estuary. Elucidating mechanisms - like compensatory feeding - that enable generalist species to thrive in sub-optimal habitat conditions is critical to understand organismal ecology in the context of landscape alteration.

Key words: Compensatory feeding, prey quality, prey quantity, landscape, seascape, mangrove, Lutjanus griseus, condition, growth 


\section{Introduction}

Biodiversity loss is one of the most severe global environmental crises, and is caused primarily through human-mediated habitat loss and landscape alteration (Pimm et al. 1995; Vitousek et al. 1997). However, all species are not equally susceptible to these anthropogenic threats, and degree of niche specialization or generalization may be an important predictor of vulnerability to extinction (McKinney \& Lockwood 1999; Clavel et al. 2011). Specifically, specialist species are often lost before generalist species (Fisher et al. 2003; Munday 2004; Rooney et al. 2004), leading to increased prevalence of generalists and greater biotic homogenization in degraded environments (Wiegmann \& Waller 2006; Clavel et al. 2011). Therefore, understanding factors which allow generalists to remain successful in changing or degraded environments is critical to predict the effects of biodiversity loss on functioning of ecosystems.

Generalization is associated with trading-off the costs and benefits of being able to use varying resources (Futuyma \& Moreno 1988). For instance, specializing on high quality resources is profitable when they are abundant. However, being able to consume lower quality resources when competition for resources is high, or when resources vary greatly through time or space, may allow fitness to be maximized (Stephens \& Krebs 1986; Futuyma \& Moreno 1988). One mechanism by which generalist species may be able to compensate for lower food quality in habitat patches with sub-optimal foraging conditions is by increasing the quantity of food resources they consume. A compensatory feeding strategy has been demonstrated for many taxa when environmental conditions limit the availability of high quality foraging sites (Targett \& Targett 1990; Rueda et al. 1991; Pennings et al. 1993; Taillon et al. 2006). Yet, the mere presence of compensatory 
feeding does not necessarily mean similar levels of individual fitness are maintained. For example, Cruz-Riverva and Hay (2000) found only one of three species of herbivorous amphipods was able to maintain fitness by compensating for low food quality by eating more. Most of the studies to date that have examined how increasing consumption of low quality forage may affect consumer fitness have focused on phytophagous insects or crustacean mesograzers, especially when host plants are chemically defended (CruzRivera \& Hay 2001, 2003; Lavoie \& Oberhauser 2004; Roslin \& Salminen 2009). Whether such compensatory feeding strategies are found in higher-order consumers remains unclear (but see Kadin et al. 2012 and Schrimpf et al. 2012 for examples with seabirds).

My objective was to investigate foraging trade-offs of a generalist fish predator across an estuarine, environmental gradient. Additionally, I linked differences in trophic niche to growth rates and fish condition to determine the profitability of such trade-offs. Specifically, I hypothesized that (1) diet composition and quality would vary across the estuarine gradient, (2) the quantity of prey consumed would be inversely related to prey quality, and (3) growth rates and individual condition would be similar across sites if compensatory feeding was found.

\section{Materials and Methods}

\section{Study site}

The Loxahatchee River $\left(26^{\circ} 57^{\prime} \mathrm{N}, 80^{\circ} 06^{\prime} \mathrm{W}\right)$ is located on the southeast coast of Florida, USA and flows into the Atlantic Ocean through The Jupiter inlet (Fig. 4.1). The 
river drains a $700 \mathrm{~km}^{2}$ watershed, of which $63 \%$ is still dominated by natural habitats (South Florida Water Management District 2006). Diverse habitats are found across this landscape, transitioning from riverine cypress swamps upstream to marine-dominated mangrove and seagrass habitat closer to the river mouth. I focused on five sites across this gradient representing the range of habitats utilized by Gray snapper, Lutjanus griseus (Table 4.1). Sites span an $11 \mathrm{~km}$ gradient across this ecotone and represent a significant environmental gradient for Gray snapper. Data from acoustic telemetry studies within the Loxahatchee support the assumption that Gray snapper do not regularly move among the five study sites (Layman, C.A., unpublished data).

\section{Study species}

Gray snapper (Lutjanus griseus) is an ecologically important fisheries species common throughout Florida and the Caribbean (Starck \& Schroeder 1970). Gray snapper are considered to be generalist in both their diet (Layman et al. 2007) and habitat use (Starck \& Schroeder 1970). Juvenile and sub-adult Gray snapper can tolerate a wide range of salinities (Serrano et al. 2011) and inhabit a diverse suite of habitats including seagrass beds, oyster reefs, mangroves and human-made habitats (Eggleston et al. 2004; Tolley \& Volety 2005; Faunce \& Serafy 2007). While some adult snapper may move offshore as adults, many may remain as estuarine residents throughout their lifetime (Faunce \& Serafy 2008b). 


\section{Data collection}

Fish were collected for growth and diet analysis by fishing with baited hooks (all sites), supplemented by electrofishing upstream. Fish were euthanized using a high dosage of eugenol (a known fish anesthetic, Cotter and Rodruck 2006, Sladky et al. 2001). The standard length (SL) of each fish was measured to the nearest millimeter. Stomach contents of each fish were extracted by dissection and visually identified to the lowest taxonomic level possible. When necessary, stomach contents were brought back to the laboratory and identified with the aid of a dissecting microscope. Otoliths were extracted from the fish and taken to the laboratory for processing so that fish could be aged. Fin tissue was taken for isotopic analysis. Muscle tissue samples were collected for lipid content analysis.

Once a sufficient number of fish had been sampled for age analysis, additional fish were sampled non-lethally for stomach contents (i.e., to reduce the number of fish sacrificed) (Layman \& Winemiller 2004). These fish were anesthetized using eugenol and forced to regurgitate their stomach contents by pressing on the abdomen while using a metal spatula to help invert the stomach (Hammerschlag-Peyer \& Layman 2012). A fin clip was also taken from these fish for stable isotope analysis. After sampling their stomach contents, fish were returned to water from the study site in a cooler and allowed to recover before being released.

Carbon stable isotope analysis was used to examine shifts in basal carbon resource pools for snapper among sites. Only a subset of snapper collected in the summer of 2009 were used for stable isotope analysis (between 11 and 15 individuals per site). Fin tissue was processed for $\delta^{13} \mathrm{C}$ according to Post et al. (2007). 
Prey species identified from Gray snapper stomachs were collected opportunistically from benthic, intertidal and pelagic habitats throughout the estuary using a variety of methods (nets, traps, and by hand). Proximate composition of prey taxa (percent water, lipid, lean mass (protein), and inorganic components) was used to assess prey quality. Percent water was determined by subtracting wet weight from the dry weight after drying whole organisms to a constant weight at $60^{\circ} \mathrm{C}$. Each organism was then ground to a powder with a mortar and pestle and a sub-sample of the homogenized powder was taken. Percent total lipid in the tissue was determined gravimetrically by solvent extraction following a version of the Bligh-Dryer method (Bligh \& Dyer 1959), modified for use with a less toxic dichloromethanol solvent following Erickson (1993). Percent lean mass (protein) and inorganic material was found after burning lipidextracted tissue in a furnace at $550^{\circ} \mathrm{C}$ for 4 hours. Percent inorganic material was found by weighing the remaining ash and the amount of lean mass was calculated by subtraction (Van Pelt et al. 1997).

Fish age was determined by examination of annual rings on sagittal otoliths. Annual rings were examined under a dissecting microscope and counted by two readers (LAY and CMHP). Blind counts were recorded with no knowledge of fish size. If counts between readers differed and no consensus in count could be made, the sample was excluded. Fish were aged to fractions of a year defined by the month the fish was captured, where January 1 was always considered the start of the year by convention.

Fish condition was evaluated by the lipid content found in muscle tissue. Fish with greater percent lipid may be considered to have a higher fitness, as higher lipid stores are often associated with faster growth rates and increased reproductive output 
later in life (Hutchings 1993; Fox 1994; Sogard 1997; Booth \& Beretta 2004; Johnson 2008). Fish muscle samples were taken from the dorsal (epaxial and hypaxial) region of the posterior side of the fish. Muscle samples were dried and ground to a fine powder using a mortar and pestle. A $100 \mathrm{mg}$ subsample was used to assess lipid content. Lipids were extracted from the muscle using a version of the Bligh-Dryer method (Bligh \& Dyer $1959)$ as described for prey quality analysis.

\section{Data analysis}

For diet analysis focusing on frequency of feeding and quantity of prey consumed, only snapper captured during the morning (8:30-12:00, $\mathrm{n}=291$ individuals) were used. First, effects of fish size and site within the estuary on the frequency of snapper having food in their stomachs was tested with logistic regression. Because differences were found among sites, I tested whether distance from the mouth of the estuary predicted the proportion of snapper with food in their stomach using linear regression. Next, a general linear model (GLM) was used to test whether gut fullness (volume of food in stomach) could be predicted by site or fish size. As a measure of effect size, I also calculated $\eta^{2}$ values, which represent the proportion of unique variation explained by individual predictor variables. Whether distance from the mouth of the estuary predicted the mean gut fullness at each site was tested using linear regression.

To examine differences in diet composition among sites, stomach contents were evaluated on the basis of both the volume of prey items as well as the number. Prey were grouped into taxonomically similar categories so that each group represented at least $5 \%$ of the total diet (by volume and number) across all sites ( $n=8$ groups). A multivariate 
analysis of variance (MANOVA) was used to test whether the volume of major prey groups in snapper stomachs differed among sites. Next, a $\chi^{2}$ test of independence was used to test whether the number of individuals from different prey groups differed among sites. If significant results were obtained for the MANOVA or $\chi^{2}$ test of independence, post-hoc tests were used to determine which sites and prey taxa were driving the differences. Additionally, prey were categorized by their primary habitat type: intertidal, benthic, or pelagic, depending on life history information and observations of prey behavior and habitat use at the study sites. A similar MANOVA and $\chi^{2}$ test of independence was used to test whether the volume and number of prey, respectively, from different habitat types varied among sites. To test whether there was a shift in basal resource pool across sites, the $\delta^{13} \mathrm{C}$ were compared among sites using a Kruskal-Wallis non-parametric analysis of variance, as data did not meet assumptions of normality $(P<$ 0.05). The relationship between mean $\delta^{13} \mathrm{C}$ and distance to the mouth was tested with linear regression.

Energy density for different prey items was calculated on the basis of the proximate composition and published caloric values for lipid and lean mass (SchmidtNielson 1997). Differences in energy density among prey taxa were tested with a oneway analysis of variance (ANOVA). Prey were then divided into high (mean energy density $>5.0 \mathrm{kcal} / \mathrm{g} \mathrm{DW}$ ) and low energy density (mean energy density between 3.0 and $4.0 \mathrm{kcal} / \mathrm{g} \mathrm{DW}$ ) groups. A MANOVA was used to test whether the volume of high and low energy density prey consumed by snapper differed among sites. Whether the frequency at which snapper ate high and low energy density foods differed among sites was tested with a $\chi^{2}$ test of independence. 
Growth curves were created from on size and age data of snapper from sites 1, 3, and 5, the only sites with sufficient sample sizes to develop the curves. Linear growth models regressing log (age) and log (length) best fit observed data. Because fish used within this study were mostly juvenile and sub-adult snapper, log-linear growth models were most appropriate (Faunce \& Serafy 2008a). Growth analysis was restricted to fish between 1-3 years old as this age range was well-represented at all sites. A GLM was used to determine whether size at age and growth rates differed among sites. Differences in individual condition as measured by the percent lipid in muscle were compared among sites using a one-way ANOVA. All statistical tests were performed in SAS v 9.2 except the $\chi^{2}$ which were performed in SPSS $\mathrm{v} 19$.

\section{Results}

A total of 340 snapper were caught in the summers of 2007-2009 ranging in size $54-204 \mathrm{~mm}$ SL. The probability of a snapper having food in its stomach varied among sites $(\mathrm{df}=4, \mathrm{~W}=21.9, P=0.0002)$, but was not related to fish size $(\mathrm{df}=1, \mathrm{~W}=0.47, P$ $=0.49$ ). The proportion of snapper with food in their stomachs was positively related to

distance from the mouth of the estuary $\left(\mathrm{y}=4.01 \mathrm{x}+38.92, \mathrm{R}^{2}=0.99, P<0.001\right.$, Fig. $\left.2 \mathrm{a}\right)$. Gut fullness varied among sites $\left(\mathrm{df}=4, \mathrm{~F}=9.79, \mathrm{P}<0.0001, \eta^{2}=0.12\right)$, and was positively related to fish size $\left(\mathrm{df}=1, \mathrm{~F}=14.75, \mathrm{P}=0.0002, \eta^{2}=0.04\right)$. The mean gut fullness was positively related to distance from the mouth of the estuary $(y=0.066 x-$ 0.15, $\mathrm{R}^{2}=0.98, P<0.001$, Fig. $\left.4.2 \mathrm{~b}\right)$.

Snapper diets were composed of sixteen prey taxa across the five sites, including (ordered from most to least abundant): fiddler crab (Uca sp.), mud crabs (Xanthidae), 
green mangrove tree crab (Aratus pisonii), penaeid shrimp (Penaeidae), blue crab (Callinectes sapidus), grass shrimp (Palaemonidae), shore crab (Pachygraspus transversus), isopod (Isopoda), snapping shrimp (Alpheus sp.), plant material, anchovy (Anchoa sp.), green porcelain crab (Petrolisthes armatus), mojarra (Eucinostomus spp.), Crested goby (Lophogobius cyprinoides), ribbed mussel (Guekensia demissa), and amphipod (Amphipoda).

There was a difference in diet composition for binned prey categories (listed in Fig. $4.3 \mathrm{a})$ by volume $(\mathrm{df}=32, \mathrm{~F}=4.2, P<0.0001)$ and number $\left(\mathrm{df}=20, \chi^{2}=308.6, P<\right.$ 0.001) among sites. Post-hoc tests revealed this difference was driven by an increased reliance on blue crabs and shrimp downstream; green mangrove tree crabs and mud crabs in the mid-estuary, and fiddler crabs upstream. The habitat source of snapper prey items also differed among sites based on both volume $(\mathrm{df}=12, \mathrm{~F}=3.2, P=0.0003)$ and number $\left(\mathrm{df}=8, \chi^{2}=137.9, P<0.001\right)$. The difference was driven by an increased reliance on intertidal prey items and a decreased reliance on benthic prey items at upstream sites compared to downstream. The $\delta^{13} \mathrm{C}$ values of snapper fin samples differed among sites $(\mathrm{H}=53.4, \mathrm{P}<0.001)$. The mean $\delta^{13} \mathrm{C}$ of snapper fin tissue was negatively related to distance to the mouth $\left(\mathrm{y}=0.85 \mathrm{x}-17.8, \mathrm{R}^{2}=0.93, P=0.007\right.$, Fig. $\left.4.2 \mathrm{c}\right)$.

A total of 103 individuals from 10 prey taxa were processed for proximate composition (percent water, lipid, lean mass and inorganic material). Energy density differed significantly among prey categories $(\mathrm{df}=7, \mathrm{~F}=81.3, P<0.0001$, Fig. 4.4). The volume $(\mathrm{df}=8, \mathrm{~F}=2.60, \mathrm{P}=0.001)$ and number $\left(\mathrm{df}=4, \chi^{2}=74.83, P>0.001\right)$ of prey from high and low energy density groups varied among sites (Fig. 4.3c). Post-hoc test revealed that differences in volume were driven by a difference in the volume of low 
energy density foods, which was greatest at sites 4 and 5. Difference in the number of high and low energy density food consumed was driven by a greater than expected number of high energy density prey consumed downstream (site 1) and low energy density prey consumed upstream (site 5).

The size of Gray snapper increased with age $(\mathrm{df}=1, \mathrm{~F}=16.94, P<0.001)$, but did not vary among sites $(\mathrm{df}=2, \mathrm{~F}=1.45, P=0.24$, Fig. 4.5$)$. Growth rates (size* site) of snapper did not differ among the three sites examined $(\mathrm{df}=2, \mathrm{~F}=0.38, P=0.68)$.

Fifty-four snapper from across the five study sites were examined for lipid content in muscle as a proxy for individual condition. The percent lipid in muscle tissue ranged from $5.1 \%$ to $7.3 \%$ and did not vary among study sites $(\mathrm{df}=4, \mathrm{~F}=0.28, P=0.9$, Fig. 4.6).

\section{Discussion}

I found significant variation in the composition of Gray snapper diets and the quality and quantity of prey consumed across an environmental gradient. As may be predicted by optimal foraging models (MacArthur and Pianka 1966), the quality of prey consumed appeared to be inversely related to the quantity of prey consumed. Snapper exhibited similar growth rates and individual condition across sites, indicating that trading-off the quality and quantity of prey consumed may have allowed snapper to maintain similar measures of condition across the gradient. These results suggest that niche plasticity and compensatory feeding may be mechanisms through which Gray snapper are able to thrive across gradients of resource quality and availability. 
Snapper diets shifted substantially across the environmental gradient in terms of taxonomic composition and habitat sources. Snapper downstream fed mostly from soft bottom habitats surrounding the mangrove island from which the snapper were caught. In contrast, snapper upstream shifted to a diet more heavily reliant on intertidal prey. Carbon isotope analysis of snapper tissue supported this diet shift, as carbon values of snapper upstream were more characteristic of intertidal food webs while values of snapper downstream were reflective of more marine-based production (Yeager \& Layman 2011). Although I did not quantify the distribution of prey, benthic, pelagic, and intertidal prey were present at all sites (L.A. Yeager, personal observation). However, distribution of specific prey taxa did vary across sites and much of the variation in snapper diet composition is likely a result of these differences. For example, blue crabs are rarely observed upstream; little muddy intertidal habitat precluded fiddler crabs from downstream sites. It is likely that the estuarine gradient was an important driver of the distribution of certain prey taxa, as some of the more marine-associated prey (e.g., penaid shrimp) were excluded from upstream sites because of salinity tolerances.

While it appears that snapper have a trade-off between quality and quantity of prey consumed across the estuarine gradient, much is still to be studied about the underlying mechanisms driving diet choice. Specifically, it is not known if differences in snapper diet across this gradient are the result of differences in prey availability, prey choice, and/or time spent foraging. The question remains at sites where the quality of prey consumed is high, why not consume more? For instance, the high frequency of empty stomachs observed downstream suggests that snapper should be able to consume more if more prey were available. Increased competition downstream may have resulted 
in lower per capita prey availability. Additionally, if predator encounter rates were greater downstream, increased mortality risk may have resulted in less foraging time or a smaller foraging range. Regardless of the mechanism, it is apparent that such a trade-off between quality and quantity of prey consumed was sufficient for maintaining similar levels of growth and condition for snapper across the environmental gradient examined.

Other factors besides diet may affect condition and growth of individual Gray snapper. For example, environmental conditions such as temperature or salinity can affect physiological costs for snapper (Wuenschel et al. 2005, Serrano et al. 2011). Water temperatures varied little among my five sites, and thus likely had little effect on differences in fish condition and growth. A previous study on physiological costs associated with varying salinities indicated physiological stress in Gray snapper is unlikely to occur between 5 and $50 \mathrm{ppt}$ (Serrano et al. 2011). Only at the site farthest upstream may any physiological cost be associated with decreased salinities, and the mean salinity for this site of $4 \mathrm{ppt}$ falls only just outside the "no-stress" range. Therefore, variation in diet seems to be a more likely potential driver of snapper condition or growth as opposed to environmental factors in my system.

While I did not find evidence of reduced individual fitness for Gray snapper associated with reduced forage quality, I focused on naturally varying differences in forage quality. In contrast, in studies on fragmented tidal creek ecosystems in The Bahamas, Gray snapper were found to have reduced growth rates and lower body condition when compared to those from unfragmented creeks (Rypel \& Layman 2008). In fragmented systems in The Bahamas, prey diversity was greatly reduced and snapper were found to have a much smaller trophic niche width at these sites (Layman et al. 
2007). One hypothesis is that reduced prey availability in fragmented systems prevents snapper from compensating for reduced quality by eating more. A comparison of this system with that of the current study suggests if habitat degradation becomes too severe, foraging trade-offs may be inadequate to compensate for reduced forage quality or quantity.

Generalist species are able to thrive in numerous ecological niches because of their plastic responses to biotic and abiotic environmental variation. As species richness declines with habitat degradation, the contribution of the remaining species becomes even more critical to maintaining overall ecosystem function. Trade-offs such as compensatory feeding may be critical in allowing generalist species to deal with suboptimal conditions. However, factors such as foraging mode or the availability of alternate prey sources may limit this efficacy of this compensatory mechanism. In light of the rapid rate of species loss and landscape change, it is critical to understand how, when, and where generalist species may be able to undergo trade-offs to maintain critical functions of altered environments.

\section{Acknowledgements}

This study was funded by a National Science Foundation Graduate Research Fellowship to LAY, NSF Grant OCE \#0746164 to CAL, the Loxahatchee River District, and Florida International University. The authors thank Christina Acevedo, D. Albrey Arringtion, Kevin Bernhart, Joseph Brooker, Thomas Browning, Patricia Gonzales, Zack Jud, Evan McLean, Carlos Villegas, and Karissa Wasko for help with field work. 
Table 4.1. Description of five studies sites. Salinity and temperature data courtesy of the Loxahatchee River District from averages over 2008-2009. NA = not available.

\begin{tabular}{|l|l|l|l|l|l|}
\hline $\begin{array}{l}\text { Site } \\
\text { number }\end{array}$ & Site name & $\begin{array}{l}\text { Distance } \\
\text { from mouth } \\
\text { of estuary } \\
(\mathrm{km})\end{array}$ & $\begin{array}{l}\text { Mean } \\
\text { salinity } \\
(\mathrm{ppt})\end{array}$ & $\begin{array}{l}\text { Mean } \\
\text { temperature } \\
\left({ }^{\circ} \mathrm{C}\right)\end{array}$ & Site description \\
\hline 1 & $\begin{array}{l}\text { Bird } \\
\text { Island }\end{array}$ & 2.6 & 33 & 25.9 & $\begin{array}{l}\text { Red mangrove } \text { Rhizophora } \\
\text { mangle }) \text { islands bordered } \\
\text { by sub-tidal channels and } \\
\text { mud flats with sparse } \\
\text { seagrass }\end{array}$ \\
\hline 2 & $\begin{array}{l}\text { Eagle's } \\
\text { Nest }\end{array}$ & 5.3 & 26 & 25.8 & $\begin{array}{l}\text { Red mangrove and concrete } \\
\text { rip-rap shoreline bordered } \\
\text { by patches of muddy } \\
\text { bottom and oysters }\end{array}$ \\
\hline 3 & $\begin{array}{l}\text { Oyster } \\
\text { Island }\end{array}$ & 6.8 & 19 & 25.6 & $\begin{array}{l}\text { Red mangrove islands } \\
\text { surrounded by extensive } \\
\text { oyster reefs }\end{array}$ \\
\hline 5 & $\begin{array}{l}\text { Boy } \\
\text { Scout } \\
\text { Camp }\end{array}$ & 9.9 & 9 & NA & $\begin{array}{l}\text { Red mangrove shorelines } \\
\text { bordered by muddy bottom } \\
\text { with sparse oyster clumps }\end{array}$ \\
\hline 5 & $\begin{array}{l}\text { Kreek } \\
\text { Citching }\end{array}$ & 13.1 & 4 & 25.1 & $\begin{array}{l}\text { Freshwater cypress } \\
\text { Taxodium distichum }) \text { and } \\
\text { riverine mangrove-lined } \\
\text { shoreline, bordered by } \\
\text { muddy bottom }\end{array}$ \\
\hline
\end{tabular}




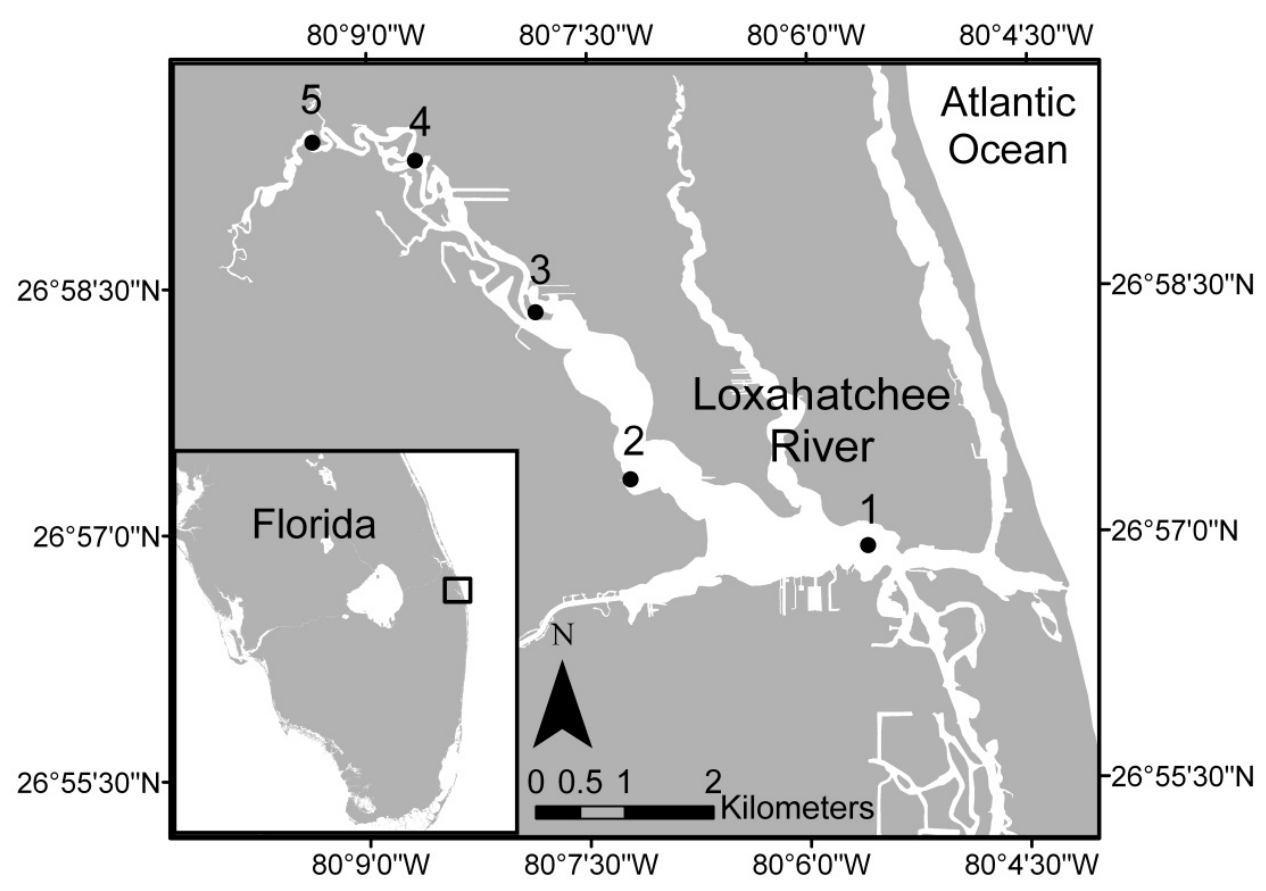

Fig. 4.1. Map of the Loxahatchee River and estuary. Black dots indicate locations of the five study sites. 

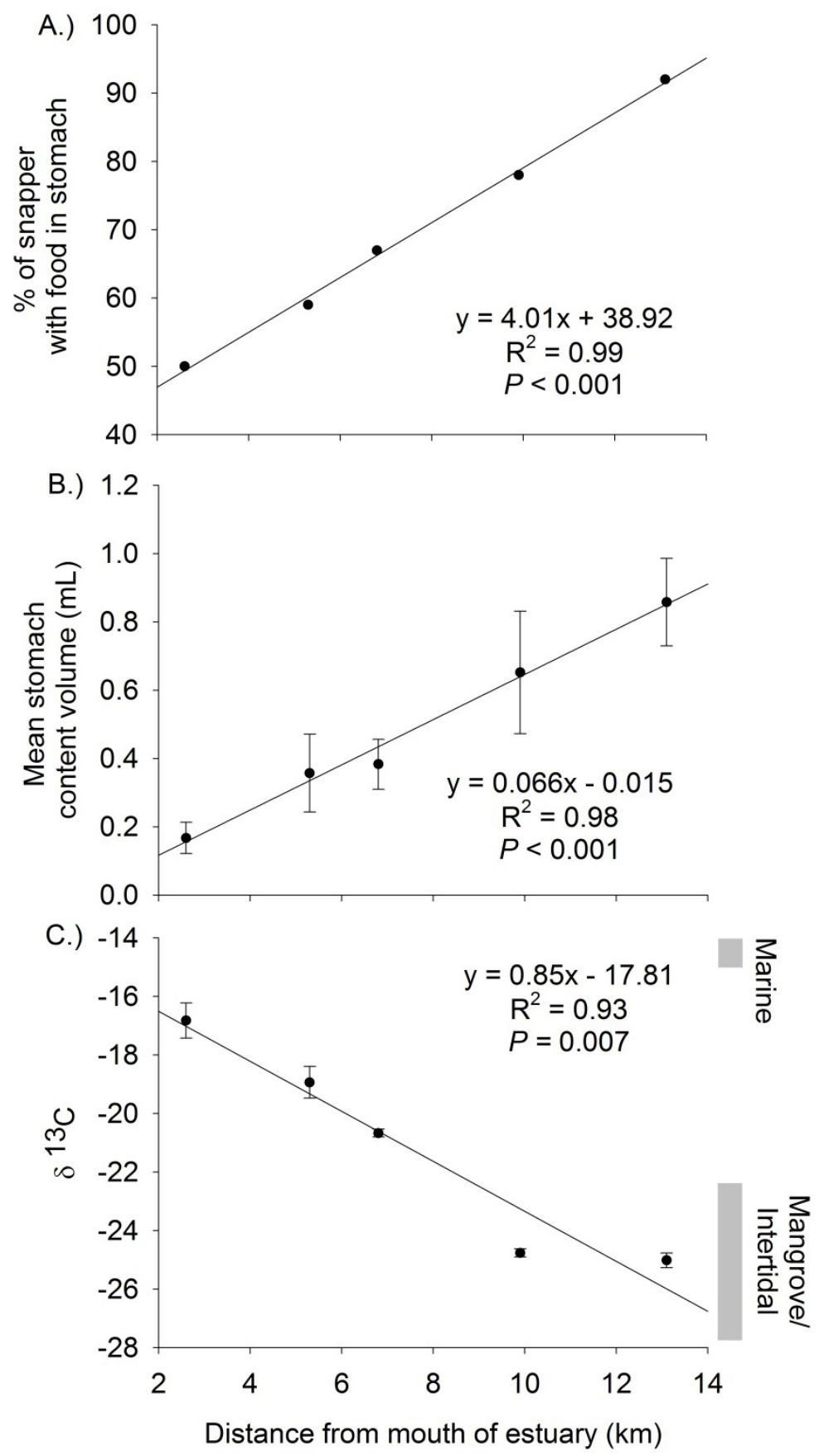

Fig. 4.2. Aspects of snapper diet along an estuarine gradient: (a) percent of snapper with food in their stomachs, (b) mean ( \pm standard error) gut fullness, and (c) mean ( \pm standard error) $\delta^{13} \mathrm{C}$ of Gray snapper fin tissue from 5 sites along the gradient. Gray bars to the right of plot represent range of $\delta^{13} \mathrm{C}$ values from marine or mangrove/intertidal carbon source pools in the estuary. 


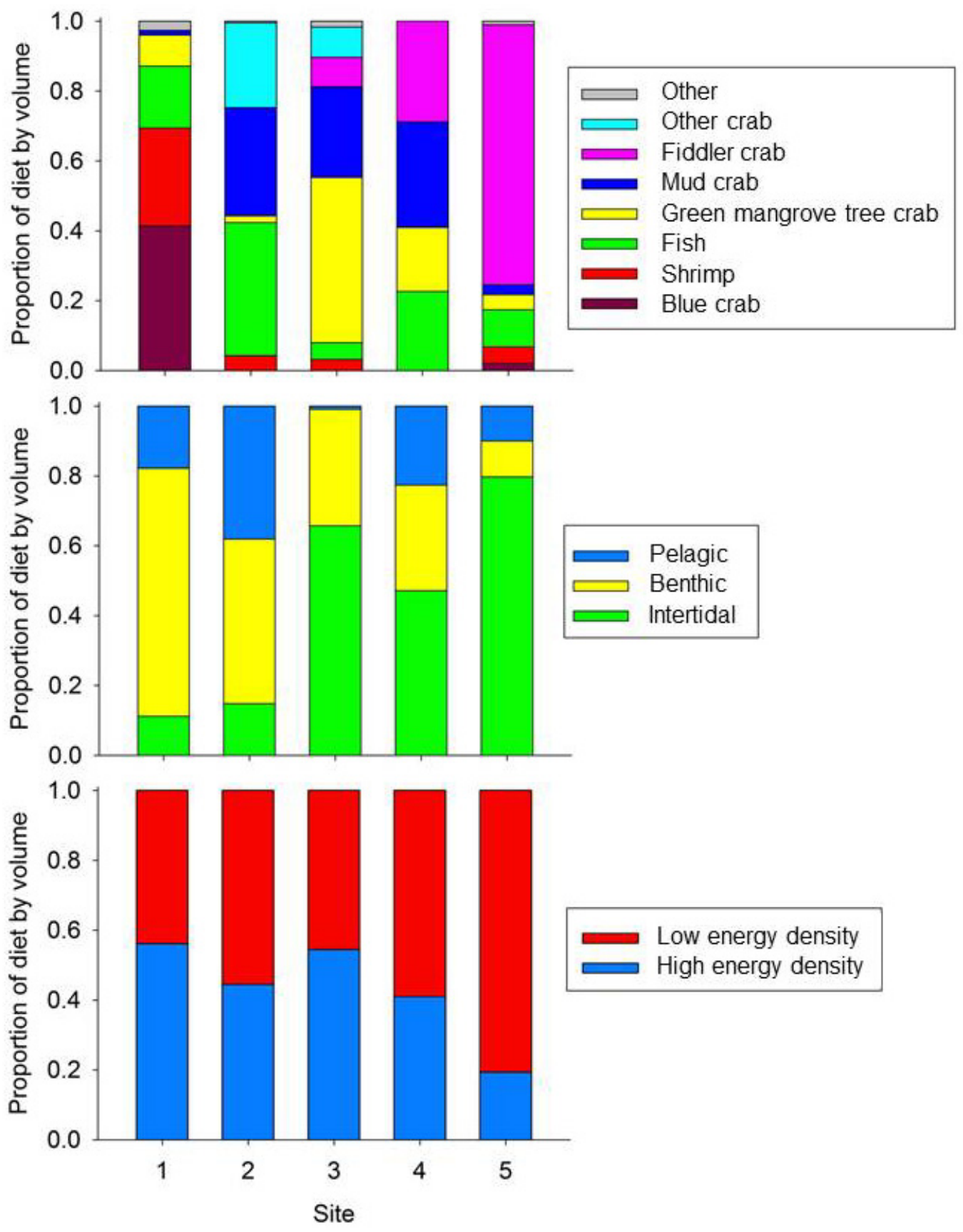

Fig. 4.3. Composition of Gray snapper diets by volume based on (a) major taxonomic groupings of prey, (b) habitat source of prey items, and (c) quality of prey from 5 study sites. I present only data based on volume for simplicity, as patterns for diets based on number were generally similar. 


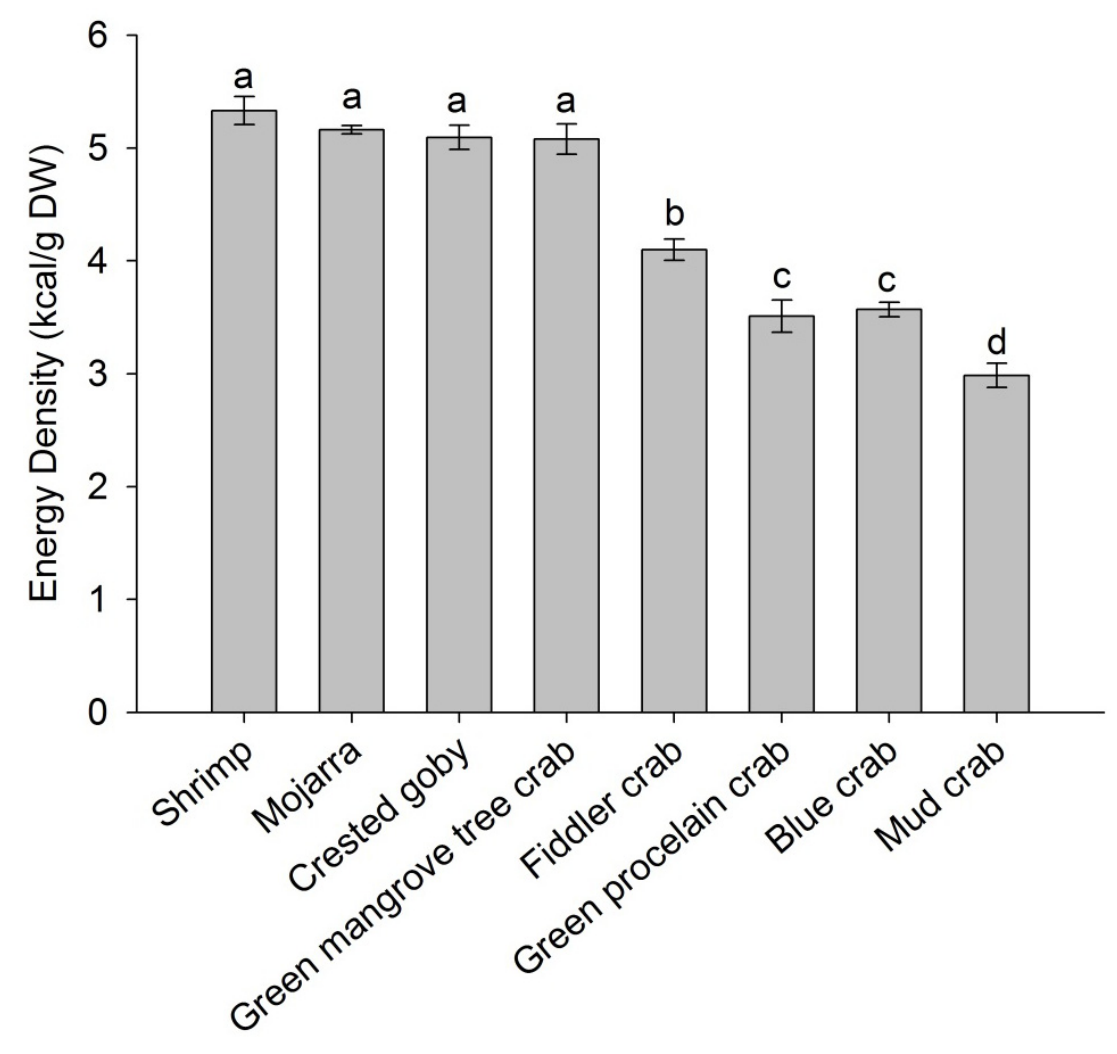

Fig. 4.4. Mean ( \pm standard error) energy density of snapper prey items in kcal/g DW. Similar letters denote groups that do not differ statistically at $\alpha=0.05$. 


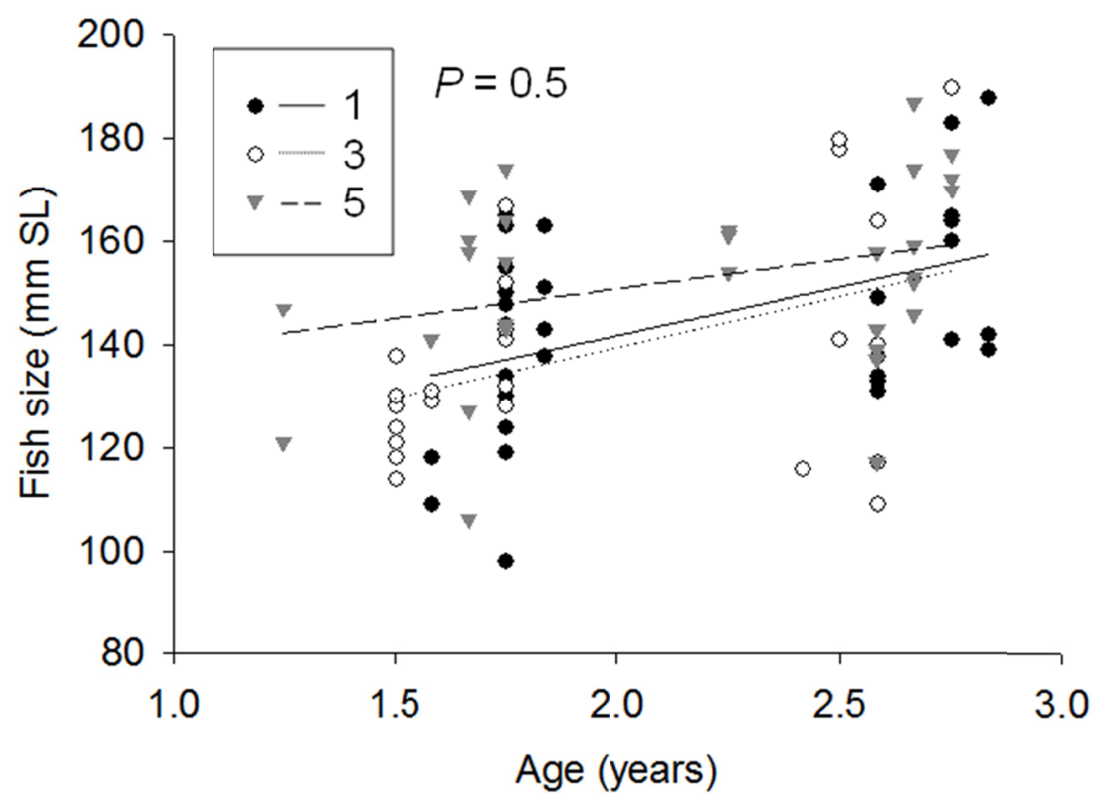

Fig. 4.5. Linear growth curves based on log (age) versus log (length) for snapper from 5 sites along the environmental gradient. 


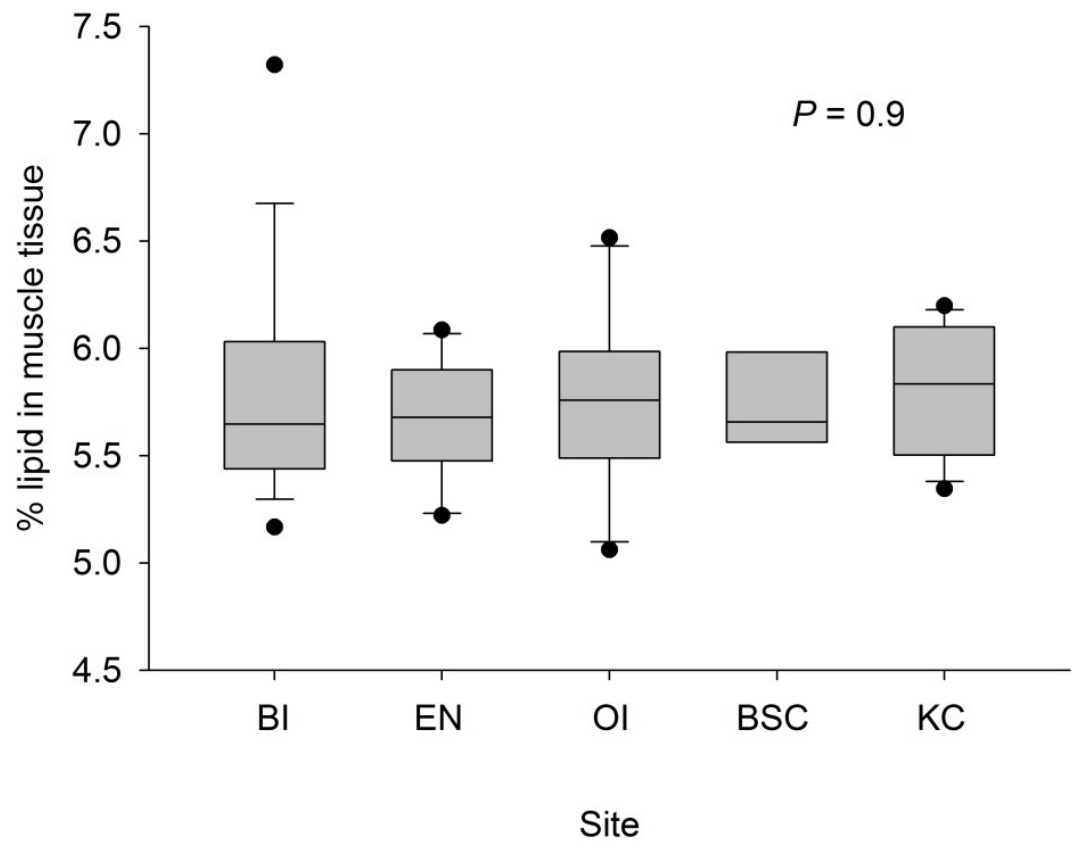

Fig. 4.6. Box plots of \% lipid in muscle based on dry weight for Gray snapper from 5 sites along an environmental gradient. 


\section{Literature cited}

Bligh, E., and Dyer, W. 1959. A rapid method of total lipid extraction and purification. Can. J. Biochem. Physiol. 37(8): 911-917.

Booth, D.J., and Beretta, G.A. 2004. Influence of recruit condition on food competition and predation risk in a coral reef fish. Oecologia 140(2): 289-294.

Clavel, J., Julliard, R., and Devictor, V. 2011. Worldwide decline of specialist species: toward a global functional homogenization? Front. Ecol. Environ. 9(4): 222-228.

Cotter, P.A., and Rodruck, K.J. 2006. Differential effects of anesthetics on electrical properties of the rainbow trout (Oncorhynchus mykiss) heart. Comp. Biochem. Physiol., Part A: Mol. Integr. Physiol. 145(2): 158-165.

Cruz-Rivera, E., and Hay, M.E. 2000. Can quantity replace quality? food choice, compensatory feeding, and fitness of marine mesograzers. Ecology 81(1): 201219.

Cruz-Rivera, E., and Hay, M.E. 2001. Macroalgal traits and the feeding and fitness of an herbivorous amphipod: the roles of selectivity, mixing, and compensation. Mar. Ecol. Prog. Ser. 218: 249-266.

Cruz-Rivera, E., and Hay, M.E. 2003. Prey nutritional quality interacts with chemical defenses to affect consumer feeding and fitness. Ecol. Monogr. 73(3): 483-506.

Eggleston, D.B., Dahlgren, C.P., and Johnson, E.G. 2004. Fish density, diversity, and size-structure within multiple back reef habitats of Key West National Wildlife Refuge. Bull. Mar. Sci. 75(2): 175-204.

Erickson, M.C. 1993. Lipid extraction from channel catfish muscle: comparison of solvent systems. J. Food Sci. 58(1): 84-89.

Faunce, C.H., and Serafy, J.E. 2007. Nearshore habitat use by gray snapper (Lutjanus griseus) and bluestriped grunt (Haemulon sciurus): environmental gradients and ontogenetic shifts. Bull. Mar. Sci. 80(3): 473-495.

Faunce, C.H., and Serafy, J.E. 2008a. Growth and secondary production of an eventual reef fish during mangrove residency. Estuar. Coast. Shelf Sci. 79(1): 93-100.

Faunce, C.H., and Serafy, J.E. 2008b. Selective use of mangrove shorelines by snappers, grunts, and great barracuda. Mar. Ecol. Prog. Ser. 356: 153-162.

Fisher, D.O., Blomberg, S.P., and Owens, I.P.F. 2003. Extrinsic versus intrinsic factors in the decline and extinction of Australian marsupials. Proc. R. Soc. Lond. Ser. BBiol. Sci. 270(1526): 1801-1808. 
Fox, M.G. 1994. Growth, Density, and Interspecific Influences on Pumpkinseed Sunfish Life-Histories. Ecology 75(4): 1157-1171.

Futuyma, D.J., and Moreno, G. 1988. The evolution of ecological specialization. Annu. Rev. Ecol. Syst. 19: 207-233.

Hammerschlag-Peyer, C.M., and Layman, C.A. 2012. Factors affecting resource use variation for an abundant coastal fish predator, Lutjanus apodus, in a Bahamian wetland system. Bull. Mar. Sci. 88(2): 211-230.

Hutchings, J.A. 1993. Adaptive life histories effected by age-specific survival and growth rate. Ecology 74(3): 673-684.

Johnson, D.W. 2008. Combined effects of condition and density on post-settlement survival and growth of a marine fish. Oecologia 155(1): 43-52.

Kadin, M., Osterblom, H., Hentati-Sundberg, J., and Olsson, O. 2012. Contrasting effects of food quality and quantity on a marine top predator. Mar. Ecol. Prog. Ser. 444: 239-249.

Lavoie, B., and Oberhauser, K.S. 2004. Compensatory feeding in Danaus plexippus (Lepidoptera : Nymphalidae) in response to variation in host plant quality. Environ. Entomol. 33(4): 1062-1069.

Layman, C.A., Quattrochi, J.P., Peyer, C.M., and Allgeier, J.E. 2007. Niche width collapse in a resilient top predator following ecosystem fragmentation. Ecol. Lett. 10(10): 937-944.

Layman, C.A., and Winemiller, K.O. 2004. Size-based responses of prey to piscivore exclusion in a species-rich neotropical river. Ecology 85(5): 1311-1320.

MacArthur, R.H., and Pianka, E.R. 1966. On optimal use of a patchy environment. Am. Nat. 100(916): 603-609.

McKinney, M.L., and Lockwood, J.L. 1999. Biotic homogenization: a few winners replacing many losers in the next mass extinction. Trends Ecol. Evol. 14(11): 450-453.

Munday, P.L. 2004. Habitat loss, resource specialization, and extinction on coral reefs. Glob. Change Biol. 10(10): 1642-1647.

Pennings, S.C., Nadeau, M.T., and Paul, V.J. 1993. Selectivity and growth of the generalist herbivore Dolabella auricularia feeding upon complementary resources. Ecology 74(3): 879-890.

Pimm, S.L., Russell, G.J., Gittleman, J.L., and Brooks, T.M. 1995. The future of biodiversity. Science 269(5222): 347-350. 
Post, D.M., Layman, C.A., Arrington, D.A., Takimoto, G., Quattrochi, J., and Montana, C.G. 2007. Getting to the fat of the matter: models, methods and assumptions for dealing with lipids in stable isotope analyses. Oecologia 152(1): 179-189.

Rooney, T.P., Wiegmann, S.M., Rogers, D.A., and Waller, D.M. 2004. Biotic impoverishment and homogenization in unfragmented forest understory communities. Conserv. Biol. 18(3): 787-798.

Roslin, T., and Salminen, J.P. 2009. A tree in the jaws of a moth - temporal variation in oak leaf quality and leaf-chewer performance. Oikos 118(8): 1212-1218.

Rueda, A.A., Slansky, F., and Wheeler, G.S. 1991. Compensatroy feeding response of the slug Sarasinula plebeia to dietary dilution. Oecologia 88(2): 181-188.

Rypel, A.L., and Layman, C.A. 2008. Degree of aquatic ecosystem fragmentation predicts population characteristics of gray snapper (Lutjanus griseus) in Caribbean tidal creeks. Can. J. Fish. Aquat. Sci. 65(3): 335-339.

Schmidt-Nielson, K. 1997. Animal Physiology: Adaptation and Environment. Cambridge Univeristy Press, New York.

Schrimpf, M.B., Parrish, J.K., and Pearson, S.F. 2012. Trade-offs in prey quality and quantity revealed through the behavioral compensation of breeding seabirds. Mar. Ecol. Prog. Ser. 460: 247-259.

Serrano, X., Serafy, J., and Grosell, M. 2011. Osmoregulatory capabilities of the gray snapper, Lutjanus griseus: salinity challenges and field observations. Mar. Freshw. Behav. Physiol. 44(3): 185-196.

Sladky, K.K., Swanson, C.R., Stoskopf, M.K., Loomis, M.R., and Lewbart, G.A. 2001. Comparative efficacy of tricaine methanesulfonate and clove oil for use as anesthetics in red pacu (Piaractus brachypomus). Am. J. Vet. Res. 62(3): 337342 .

Sogard, S.M. 1997. Size-selective mortality in the juvenile stage of teleost fishes: A review. Bull. Mar. Sci. 60(3): 1129-1157.

South Florida Water Mangement District. 2006. Restoration plan for the Northwest fork of the Loxahatchee River.

Starck, W.A., and Schroeder, R.E. 1970. Investigations of the Gray Snapper, Lutjanus griseus. University of Miami Press, Coral Gables, FL, USA.

Stephens, D.W., and Krebs, J.R. 1986. Foraging Theory. Princeton University Press, Princeton, New Jersey, USA.

Taillon, J., Sauve, D.G., and Cote, S.D. 2006. The effects of decreasing winter diet quality on foraging behavior and life-history traits of white-tailed deer fawns. J. Wildl. Manag. 70(5): 1445-1454. 
Targett, T.E., and Targett, N.M. 1990. Energetics of food selection by the herbivorous parrotfish Sparisoma radians: roles of assimilation efficiency, gut evacuation rate, and algal secondary metabolites. Mar. Ecol. Prog. Ser. 66(1-2): 13-21.

Tolley, S.G., and Volety, A.K. 2005. The role of oysters in habitat use of oyster reefs by resident fishes and decapod crustaceans. J. Shellfish Res. 24(4): 1007-1012.

Van Pelt, T.I., Piatt, J.F., Lance, B.K., and Roby, D.D. 1997. Proximate composition of energy density of some North Pacific forage fishes Comp. Biochem. Physiol. 118A(4): 1393-1398.

Vitousek, P.M., Mooney, H.A., Luchenco, J., and Melillo, J.M. 1997. Human domination of earth's ecosystems. Science 277: 494-499.

Wiegmann, S.M., and Waller, D.M. 2006. Fifty years of change in northern upland forest understories: Identity and traits of "winner" and "loser" plant species. Biol. Conserv. 129(1): 109-123.

Wuenschel, M.J., Jugovich, A.R., and Hare, J.A. 2005. Metabolic response of juvenile gray snapper (Lutjanus griseus) to temperature and salinity: Physiological cost of different environmets. J. Exp. Mar. Biol. Ecol. 321(2): 145-154.

Yeager, L.A., and Layman, C.A. 2011. Energy flow to two abundant consumers in a subtropical oyster reef food web. Aquat. Ecol. 45(2): 267-277. 


\section{CHAPTER V}

ENERGY FLOW TO TWO ABUNDANT CONSUMERS IN A SUB-TROPICAL OYSTER REEF FOOD WEB 
ABSTRACT Oyster reefs are among the most threatened coastal habitat types, but still provide critical habitat and food resources for many estuarine species. The structure of oyster-reef food webs is an important framework from which to examine the role of these reefs in supporting high densities of associated fishes. I identified major trophic pathways to two abundant consumers, Gray snapper (Lutjanus griseus) and Crested goby (Lophogobius cyprinoides), from a sub-tropical oyster reef using stomach content and stable isotope analysis. The diet of Gray snapper was dominated by crabs, but shrimp and fishes were also important. Juvenile Gray snapper fed almost entirely on oyster reefassociated prey items, while sub-adults fed on both oyster reef- and mangrove-associated prey. On the basis of trophic guilds of the Gray snapper prey, as well as relative $\delta^{13} \mathrm{C}$ values, microphytobenthos is the most likely basal resource pool supporting Gray snapper production on oyster reefs at my study site. Crested goby had omnivorous diets dominated by bivalves, small crabs, detritus, and algae, and thus were able to take advantage of prey relying on production from sestonic, as well as microphytobenthos, source pools. In this way, Crested goby represent a critical link of sestonic production to higher trophic levels. My results highlight major trophic pathways supporting secondary production in oyster reef habitat, thereby elucidating the feeding relationships that render oyster reefs critical habitat for many ecologically and economically important fish species.

Key words Diet, Estuary, Lutjanus griseus, Lophogobius cyprinoides, Predator-prey dynamics, Stable isotope analysis 


\section{Introduction}

Oyster reefs have suffered severe declines worldwide as a result of overharvest and anthropogenic habitat degradation, driving oysters to ecological extinction in many temperate estuaries (Jackson et al. 2001; Beck et al. 2009). Yet, oyster reefs remain one of the most important estuarine habitat types because of the number of ecosystem services they provide. One such service includes provision of habitat structure, as oysters form structurally complex reefs thereby providing refuge for diverse communities of fishes and invertebrates (Tolley \& Volety 2005; Boudreaux et al. 2006; Shervette \& Gelwick 2008). Many of these organisms are direct food resources for commercially important species, such as Blue crabs and Striped bass (Harding \& Mann 2001, 2003; Grabowski et al. 2008). As such, the structure of oyster-reef food webs can provide a context to evaluate one of the important ecosystem services that these habitats provide, i.e., trophic support for ecologically and economically important estuarine species.

Two food web approaches are typically employed to explore trophic relationships: interaction webs and energy flow webs (Paine 1980; Polis \& Winemiller 1996). Interaction models are usually derived from controlled experimental manipulations to determine the per capita impact of one species on another (Paine 1992). Most studies of oyster-reef food webs have utilized this approach (Grabowski 2004; Fodrie et al. 2008; Grabowski et al. 2008; O'Connor et al. 2008). Alternatively, food web models developed using direct dietary information or stable isotope values depict the flow of energy among species in an ecosystem. Such "energy flow models" are most useful for understanding which production sources and trophic pathways support particular species of interest 
(Paine 1980; Winemiller \& Polis 1996; Layman et al. 2005). An energy flow approach has rarely been taken in studies of oyster-reef food webs (but see (Dame \& Patten 1981; Lenihan et al. 2001; Wilson et al. 2009), and thus underlying trophic pathways supporting consumers are typically only inferred from functional relationships for many oyster reef systems. Furthermore, most studies examining trophic relationships in oyster reef food webs are restricted to temperate reefs, and little is known about oyster reef food webs in sub-tropical settings.

In this study, I use an energy flow approach to identify important trophic pathways supporting the production of fish consumers. I combine stomach content and stable isotope data to analyze the trophic role of these consumers. Direct diet observation through stomach content analysis provides detailed information on typical prey items. However, stomach content analysis gives only a snapshot of an individual's diet and may bias the importance of individual taxa towards the most common or those with longer residence times in the gut. Conversely, stable isotope analysis is widely employed in food web studies to provide insight into an individual's integrated diet over longer time scales (Layman \& Post 2008). The $\delta^{13} \mathrm{C}$ value (derived from the ratio of ${ }^{13} \mathrm{C}$ to ${ }^{12} \mathrm{C}$ ) often varies among primary producers with different photosynthetic pathways and is useful in inferring basal carbon resource pools supporting a consumer, since there is little change with trophic transfers (Peterson \& Fry 1987; Wada et al. 1991; Post 2002). Alternatively, the $\delta^{15} \mathrm{~N}$ value (derived from the ratio of ${ }^{15} \mathrm{~N}$ to ${ }^{14} \mathrm{~N}$ ) becomes more enriched with each trophic transfer, and therefore is useful in estimating trophic position within a food web (Cabana \& Rasmussen 1996; Vander Zanden \& Rasmussen 1999; Post 2002). I use these 
two complementary techniques to gain insight into the major trophic pathways which support production of consumers.

I focused my study on two of the most abundant consumers found on sub-tropical oyster reefs: (1) the predatory Gray snapper (Lutjanus griseus Linnaeus 1758) and (2) the omnivorous Crested goby (Lophogobius cyprinoides Pallas 1770). Gray snapper is one of the most ecologically important species in sub-tropical estuaries of the southeast U.S. and the Caribbean region, as well as an important fishery species (Layman \& Silliman 2002; Serafy et al. 2003; Layman et al. 2007; Pittman et al. 2007b; Valentine-Rose et al. 2007b). Crested goby are one of the most numerically dominant fish species on subtropical oyster reefs (Tolley et al. 2006), and thus likely play an important role in their structure and dynamics. My objectives were to describe the trophic pathways supporting Gray snapper and Crested goby and, simultaneously, reveal detail as to the structure of the overall oyster reef food web.

\section{Materials and Methods}

Study site

The Loxahatchee River $\left(26^{\circ} 57^{\prime} \mathrm{N}, 80^{\circ} 06^{\prime} \mathrm{W}\right)$ is located on the southeast Atlantic coast of Florida, United States of America, draining a $620 \mathrm{~km}^{2}$ watershed and connecting to the ocean through Jupiter Inlet. The Northwest Fork of the Loxahatchee River has been nationally designated a Wild and Scenic River, making it the first river in Florida to hold such a designation (Chapter 83-358, Laws of Florida, approved June 1983). Sixty-three 
percent of the watershed is still dominated by natural environments (South Florida Water Management District 2006). The Loxahatchee River and estuary encompass diverse aquatic habitats including freshwater cypress swamps, mangrove shorelines, seagrass beds and oyster reefs. Oyster reefs are common in the mesohaline section of the river (Fig. 5.1). A 2008 survey of oyster reef habitat by the Loxahatchee River District mapped 91 oyster reefs covering more than $60,000 \mathrm{~m}^{2}$ (Howard \& Arrington 2008). The present study will focus on an area of extensive natural oyster habitats surrounding mangrove islands $\left(26^{\circ} 58^{\prime} 16 \mathrm{~N}, 80^{\circ} 07^{\prime} 41 \mathrm{~W}\right)$ in the Northwest Fork of the river (Fig. 5.1).

\section{Study species}

Gray snapper is an important estuarine species and is a conspicuous predator in multiple estuarine habitat types. They are often associated with mangroves, seagrass and coral reef environments (Eggleston et al. 2004; Layman et al. 2004; Faunce \& Serafy 2007;

Valentine-Rose et al. 2007a; Faunce \& Serafy 2008b, a), and also are abundant on oyster reefs (Tolley \& Volety 2005). The species supports economically important recreational and small-scale commercial fisheries (Valentine-Rose et al. 2007b). Gray snapper are known generalists with respect to both trophic role (Layman et al. 2007) and physiological tolerances (Serrano et al. 2007). Juveniles are one of the most numerically dominant fishes on oyster reefs in the Loxahatchee River, Florida (C. Layman, unpublished data) and likely play an important role in the estuarine food web.

Crested goby is one of the most abundant fish species on sub-tropical oyster reefs (Tolley et al. 2006) and is the dominant benthic fish consumer in terms of biomass in the 
study area (Layman, CA, unpublished data). Crested goby are suspected to have omnivorous diets (Darcy 1981). Furthermore, Crested goby may serve as important prey for piscivores in oyster-reef food webs, including Gray snapper (Odum \& Heald 1972). For this reason, they may represent an important energy flow pathway to higher order consumers, including commercially important fishery species.

\section{Data collection}

All fishes were collected from one oyster reef $\left(\sim 2,000 \mathrm{~m}^{2}\right.$ area $)$ at the study site. Gray snappers were collected during the summers of 2008 and 2009 using hook and line fishing. Upon capture, snapper were euthanized using an overdose of eugenol. Stomach contents were extracted by dissection, all prey items identified to the lowest taxonomic level possible, and the stomach content volume was estimated using graduated cylinders. Additional individuals were collected and anesthetized using eugenol. These snapper were sampled non-lethally using stomach regurgitation following methods modified from Layman and Winemiller (2004) and finally released. Goby were collected for stomach content analysis during the summer of 2008 using benthic tray "traps" filled with oyster shell (Rodney \& Paynter 2006). Goby were euthanized and stomach contents were analyzed in the laboratory under a dissecting microscope and volume estimated as above.

Fin tissue for stable isotope analysis was collected from a subset of snapper used for stomach content analysis. Fin tissue was used so the tissue type was consistent among all individuals, because muscle was not taken from individuals sampled non-lethally. The $\delta^{13} \mathrm{C}$ and $\delta^{15} \mathrm{~N}$ of Gray snapper fin and muscle tissue is highly correlated within 
individuals $\left(\delta^{13} \mathrm{C}\right.$ fin $=1.11\left(\delta^{13} \mathrm{C}\right.$ muscle $)+2.73, \mathrm{R}^{2}=0.95$; and $\delta^{15} \mathrm{~N}$ fin $=0.998\left(\delta^{15} \mathrm{~N}\right.$ muscle) $+0.459, \mathrm{R}^{2}=0.93, \mathrm{~N}=37$ individuals; C.A. Layman, unpublished data). Using these relationships, the small correction was made from Gray snapper fin isotope values to that of muscle values, as muscle tissue was used for other fish species in this study. Crested goby were collected from the summers of 2008 and 2009 and muscle tissue was used for isotope analysis.

On the basis of the stomach content analysis, identified taxa (Table 5.1) were collected from oyster reef habitat for stable isotope analysis using benthic tray traps described above. Live oyster (Crassostrea virginica) and ribbed mussels (Guekensia demissa) were also collected by hand from the site. Additional invertebrates and primary producers were collected from mangrove prop roots and the intertidal zone. Encrusting algae was collected by hand from mangrove prop roots. Seston (suspended organic matter and plankton) was filtered from water collected at the site with pre-combusted glass fiber filters $(0.7 \mu \mathrm{m})$. Benthic algae and associated organic material (hereafter referred to as microphytobenthos) were collected by hand by scraping the top $1 \mathrm{~mm}$ surface of intertidal sediments. Red mangrove (Rhizophora mangle) and white mangrove (Lagunculara racemosa) leaves were collected from live trees. Other fish species were collected with hook and line fishing to determine isotope values of other predators for comparison with Gray snapper and Crested goby (Table 5.1). All collections were made in the summers of 2008 and 2009 to reduce seasonal variability in isotope values and seasonal differences in prey abundance.

For all mollusks, only the soft tissue was extracted for isotope analysis. For arthropods, the whole organism was used, but separate analyses were done for $\delta^{13} \mathrm{C}$ and 
$\delta^{15} \mathrm{~N}$ with the sample for $\delta^{13} \mathrm{C}$ being first acidified to remove inorganic carbon. Similarly, all tissue was acidified before $\delta^{13} \mathrm{C}$ analysis for seston, microphytobenthos, and epiphytic algae mats. All tissue samples were processed and analyzed for $\delta^{13} \mathrm{C}$ and $\delta^{15} \mathrm{~N}$ isotopic content following Post et al. (2007). A quantitative model, such as IsoSource (Phillips \& Gregg 2003), was not used to identify the exact proportions of resource pools supporting consumers because my sampling of primary producers was not sufficient to encompass primary producer spatial and temporal variability in isotope values. But snapshot $\delta^{13} \mathrm{C}$ values of primary producers provide a valuable complement to information gained from direct stomach content and isotope data on consumers (Layman \& Post 2008).

\section{Data analysis}

The proportion of prey from various taxonomic groups in the consumer diets was analyzed. Because body size can affect the diet and trophic role of consumers (Werner \& Gilliam 1984), and Gray snapper collected in this study spanned a large range in body size, I divided them into juvenile ( $<100 \mathrm{~mm} \mathrm{SL})$ and sub-adult (100-200mm SL) groups following Faunce and Serafy (2007). The diets of juvenile Gray snapper, sub-adult Gray snapper and Crested goby were compared using the Schoener index (1968) of diet overlap:

$$
\mathrm{D}=1-\frac{1}{2} \Sigma\left|\mathrm{p}_{\mathrm{ij}}-\mathrm{p}_{\mathrm{ik}}\right|
$$

Where $\mathrm{D}$ is the diet overlap and $\mathrm{p}_{\mathrm{ij}}$ and $\mathrm{p}_{\mathrm{jk}}$ are the proportions of the $\mathrm{i}^{\text {th }}$ prey taxa for species/group $\mathrm{j}$ and $\mathrm{k}$, respectively. Diets with overlap less than $\sim 60 \%$ typically are considered to be a biologically different (Zaret \& Rand 1971; Mathur 1977; Wallace 
1981). Additionally, prey were categorized according to their primary habitat: (1) benthic, oyster reef-associated, or (2) intertidal, mangrove-associated, defined by their collection locations and extensive observations of prey behavior at the site. None of the prey taxa are commonly found in both habitat types. Proportion of prey from each habitat was compared among juvenile Gray snapper, sub-adult Gray snapper and Crested goby with a Chi-squared test. Stomach contents from unknown sources were excluded in this analysis.

Because Gray snapper varied greatly in size and both consumers were collected in two years for stable isotope analysis, I determined whether these two variables affected aspects of their diet. For Gray snapper, the relationship between fish size and frequency of empty stomachs was tested with logistic regression, with year included as an additional predictor variable. Two separate Mixed Linear Models (PROC MIXED, SAS 9.2) were used to test for differences in $\delta^{13} \mathrm{C}$ or $\delta^{15} \mathrm{~N}$ between Gray snapper and Crested goby. The effects of year (2008 and 2009), fish size, and interactions between fish species and year (species x year) and size (species x size) were included as additional predictor variables. In the event of a significant interaction term, least square means with a Tukey-Kramer adjustment were calculated. Data were log-transformed when necessary to meet assumptions of normality (Kolmogorov-Smirnov test, $P>0.05$ in all cases).

\section{Results}

Ninety-six Gray snapper ranging in size from 54-190 mm standard length were collected during the summers of $2008(\mathrm{~N}=44)$ and $2009(\mathrm{~N}=52)$. Snapper were observed to have 
empty stomachs in $33 \%$ of individuals examined. The probability of a snapper having an empty stomach was not predicted by fish size $(\mathrm{W}=0.50, P=0.5)$ or collection year $(\mathrm{W}=$ $0.66, P=0.5$ ). Thirteen taxa were identified in snapper diets, including (ordered from most to least important in terms of volumetric proportions) mangrove tree crab (Aratus pisonii), black-fingered mud crab (Eurypanopeus sp. and Panopeus sp.), grapsid crab (Sesarma sp.), snapping shrimp (Alpheus sp.), goby (Gobidae), ribbed mussel, isopod (Isopoda), amphipod (Amphipoda), grass shrimp (Palaeomonetes sp.), shore crab (Pachygraspus transversus), fiddler crab (Uca sp.), and plant material. Amphipod was only present in snapper diets in 2008 and fiddler crab in 2009, but were represented by only one individual in each case. The order of importance for the remaining prey taxa in snapper diets varied slightly between years, but this difference was largely the result of the proportion of juvenile snapper sampled relative to sub-adults sampled varying slightly between years and dietary differences between these two groups (see below). Overall, snapper diets were dominated by crabs by volume $(85.4 \%)$, with lesser contributions of fish (4.2\%) and shrimp (2.8\%).

Diet overlap between juvenile and sub-adult Gray snapper was low (25.8 \%). Juvenile Gray snapper diets were dominated by mud crabs ( $53.0 \%$ of diet by volume), whereas sub-adult diets had a larger proportion of green mangrove tree crabs $(40.6 \%$, Fig. 5.2a). Primary habitat of Gray snapper prey items also differed between size classes (Fig. $5.2 \mathrm{~b})$. Juvenile diets were dominated by benthic, oyster reef prey items ( $93.0 \%$ of diet by volume, only 2 individual isopods were consumed by juveniles from mangrove habitat) while sub-adult Gray snapper shift to a diet where the majority of prey items were from intertidal, mangrove habitat (65.3\%). 
Fifty-four Crested goby (26-52 mm SL) were collected for diet analysis in the summer of 2008. Goby had empty stomachs $63 \%$ of the time. Analysis of goby diets revealed seven distinct taxa, including (ordered from most to least important by volumetric proportions) mud crab, ribbed mussel, clams and other mussels (Bivalvia), detritus, green porcelain crab (Petrolisthes armatus), filamentous algae, and snapping shrimp (Alpheidae). Goby diets were dominated in volume by bivalves (35.3\%), crabs (32.3\%), and detritus and algae (23.5\%). Diet overlap between Crested goby and juvenile snapper, and between Crested goby and sub-adult snapper was low (25.8\% and $19.8 \%$, respectively). The source of goby prey was entirely from within benthic oyster habitat (100\%). The proportion of prey from the two habitats (benthic, oyster vs. intertidal, mangrove) varied significantly between juvenile snapper, sub-adult snapper, and Crested goby $\left(\mathrm{df}=2, \chi^{2}=140, P<0.0001\right)$.

The $\delta^{15} \mathrm{~N}$ values did not differ significantly between Gray snapper and Crested goby $(\mathrm{df}=1, \mathrm{~F}=0.95, P=0.3)$, between years $(\mathrm{df}=1, \mathrm{~F}=1.79, P=0.2)$, nor with fish size $(\mathrm{df}=1, \mathrm{~F}=0.34, P=0.6)$. The $\delta^{13} \mathrm{C}$ did not differ overall between species $(\mathrm{df}=1, \mathrm{~F}$ $=0.05, P=0.8)$ or with fish size $(\mathrm{df}=1, \mathrm{~F}=0.94, P=0.3)$. There was a significant difference in $\delta^{13} \mathrm{C}$ between years $(\mathrm{df}=1, \mathrm{~F}=22.41, P<0.0001)$. However, this difference between years was driven by a significant interaction between species and year $(\mathrm{df}=1, \mathrm{~F}=11.39, P=0.002)$ Post-hoc tests revealed that $\delta^{13} \mathrm{C}$ varied between years for Gray snapper only $(P<0.0001)$, being more depleted in $2008($ mean $\pm \mathrm{SD}=-23.5 \pm 1.08)$ when compared to $2009(-21.2 \pm 1.4)$.

The mean $\delta^{15} \mathrm{~N}$ value for other oyster reef-associated species ranged from 2.3 for periwinkle snails (Littorina sp.) to 13.3 for dog snapper (Lutjanus jocu). The $\delta^{15} \mathrm{~N}$ of 
Gray snapper and Crested goby were among the highest measured (Table 5.1). Both consumers had intermediate $\delta^{13} \mathrm{C}$ values compared to the range of $\delta^{13} \mathrm{C}$ from all oyster reef fauna sampled (-13.5 to -26.7), and were within the range of prey items identified from diet analysis (Table 5.1, Fig. 5.3). While $\delta^{13} \mathrm{C}$ values were variable for primary producers, seston were isotopically-depleted compared to other producers (Fig. 5.3). Likely because of this depleted resource pool, filter feeding bivalves were more depleted in $\delta^{13} \mathrm{C}$ than all other oyster reef consumers.

\section{Discussion}

Oyster reef-associated fauna were found to be important food resources for both Gray snapper and Crested goby. Gray snapper relied on food resources from both oyster reef and intertidal mangrove habitats, while Crested goby diets were composed entirely of oyster reef fauna. Gray snapper at my study site shifted from a diet almost completely composed of oyster-reef fauna as juveniles, to consuming a large proportion of intertidal prey associated with mangroves as sub-adults. Therefore, oyster reefs may be most important to the production of newly settled, juvenile Gray snapper. While juvenile Gray snapper and Crested goby both feed almost exclusively within the oyster matrix, they exhibited little diet overlap.

Relative predation risk may drive foraging patterns and habitat choice of organisms inhabiting oyster reefs (Werner \& Hall 1988; Dahlgren \& Eggleston 2000). Even though all fish were collected from within oyster reef habitat, sub-adult Gray snapper were found to forage in adjacent mangrove habitats. In my system, mangroves 
and oyster are in close proximity (the distance between mangrove prop root habitat and the oyster matrix ranges from one to tens of $\mathrm{m}$ ), but the structure provided by the mangrove fringe is larger and devoid of clumps of oyster or other small structure. Furthermore, the mangrove fringe is only flooded at high tide, forcing fish back into the oyster matrix at low tide. Therefore, it is likely that body size contributes to the dietary differences between sub-adults snapper and juvenile and Crested goby. Sub-adult Gray snapper are larger than juvenile Gray snapper and Crested goby, possibly allowing to them escape risk from gape-limited predators. It may be more risky for the smaller juvenile snapper and Crested goby to leave the protection provided by the oyster matrix to feed in adjacent habitat. The ability of sub-adult Gray snapper to leave the oyster matrix and feed within intertidal mangrove habitats at high tide could represent a critical resource subsidy for reef-associated organisms.

Previous food web studies in oyster-reef habitats have been conducted from a different viewpoint, i.e., examining the per capita interaction strength among species. Such food webs in temperate oyster reefs focus on interactions linking filter feeding bivalves, to bivalve predators (e.g., mud crabs or oyster drills, Stramonita haemastoma), and then to top predators such as stone crabs (Menippe spp.) or oyster toadfish (Opsanus tau) (Grabowski 2004; Grabowski \& Kimbro 2005; Hughes \& Grabowski 2006; Fodrie et al. 2008; Grabowski et al. 2008). In particular, multiple studies have highlighted the importance of trophic cascades, where top predators can reduce predation by mud crabs on juvenile oysters (Grabowski 2004; Grabowski \& Kimbro 2005; Grabowski et al. 2008). In my study, I also found that mud crabs may represent a critical link in the transfer of production to higher trophic levels, since they were important components of 
the diets of both Gray snapper and Crested goby. However, on the basis of the large difference in $\delta^{13} \mathrm{C}$ values, it seems unlikely that filter feeding bivalves compose a large portion of mud crab diets in this system. Instead, other consumers, e.g., Crested goby and checkered puffer (C. Layman, unpublished data) prey directly on filter feeding bivalves. As such, piscivorous predators could be more important in controlling the abundance of bivalve predators in my study system, although these functional relationships warrant more study in sub-tropical oyster-reef food webs.

Inferences regarding trophic linkages made from stable isotope data may be ambiguous in estuarine foods, since these webs are characterized by high species diversity and numerous basal resource pools (Layman 2007). Additionally, my sampling regime did not enable me to identify all sources of variability in isotope signatures (such as those driving differences in $\delta^{13} \mathrm{C}$ of Gray snapper between years). However, the isotope data support information from consumer stomach content analysis, and by combing these two data sources, I was able to identify the most important pathways linking consumers in this oyster reef food web. In my study, production derived from sestonic sources via filter feeding organisms did not appear to contribute substantially to the diet of snapper. Instead, benthic feeding crabs, that possibly derive energy from various microphytobenthos resource pools, seem to support snapper production. Conversely, Crested goby did feed on filter-feeding bivalves, and in doing so, represent a link from sestonic production into the benthic oyster reef food web. Exotic green porcelain crabs (Knott 1999), another filter feeding organism, were also important components of the diet of Crested goby. Stable isotope data suggest that green porcelain crabs have different diets than bivalve filter feeders, perhaps because filter feeders are 
known to partition food by particle size (e.g., (Stuart \& Klumpp 1984). As such, green porcelain crabs may represent an additional trophic pathway supporting secondary production in oyster reef food webs.

The current study has focused on one large natural oyster reef, and as such, the transferability of these results across systems is largely unknown. However, I did focus on the largest natural reef within the estuary, which is similar in physiological conditions, habitat structure, and benthic community structure to other natural oyster reefs in the system (C. Layman, unpublished data). Additionally, oyster reef communities from my study site are similar in species composition to those of other sub-tropical reefs in Florida (Tolley \& Volety 2005; Tolley et al. 2005). Creating an energy flow model represents a critical first step in the development of new hypotheses related to the structure and function of these sub-tropical reef-associated food webs. I assert that more studies on the structure of sub-tropical oyster reefs are warranted in order to better understand the overall structure of these sub-tropical oyster reef food webs.

In sub-tropical and tropical ecosystems, much research has focused on the role of "nursery habitats," i.e., habitats that typically provide abundant food and/or shelter from sources of mortality (Beck et al. 2001; Dahlgren et al. 2006). Although nursery species, such as Gray snapper, are common on oyster reefs as juveniles (Tolley et al. 2005), oyster reefs do not receive the same attention as potential nurseries as do other structured habitats (e.g., seagrasses or mangrove). Herein, I have shown that oyster reefs provide important food resources for juvenile Gray snapper where they occur, as they are feeding almost entirely on prey from within the oyster matrix. In addition to providing adequate shelter, oyster habitat may provide more concentrated sources of prey compared when to 
other potential nursery habitats in the Loxahatchee River and other South Florida estuaries. Settlement-size Gray snapper have been found to recruit directly to oyster habitat (C. Layman, unpublished data) and other potential recruitment habitats, such as seagrass, are not common in the Loxahatchee. Recruitment substrate with suitable shelter may be a limiting factor for populations of nursery species (Shulman 1984; Shulman \& Ogden 1987), especially in cases where the amount of suitable juvenile habitat is small compared to adult habitat (Halpern et al. 2005). Therefore, it is likely that available oyster reef habitat may be a bottleneck limiting Gray snapper production, and that oyster reefs are critical nursery habitat within the study system.

Oyster reef habitat in the Loxahatchee has suffered severe declines (Howard \& Arrington 2008), similar to declines observed in many estuaries around the world. In the Loxahatchee estuary, this loss is primarily attributed to changing salinity regimes caused by the permanent opening of the Jupiter Inlet, as well as alteration of upstream freshwater inflows from channelization and diversion. The optimal salinity zone for oyster has shifted upstream, resulting in the death and subsequent burial of old oyster reefs. Oyster recruitment further upstream where salinities are optimal is now limited by available hard substrate. In other systems, oyster reef restoration has been shown to be an effective tool in increasing fish production (Peterson et al. 2003). Ongoing restoration of oyster habitat including increasing substrate for oyster settlement in the Loxahatchee may be critical to maintain ecosystem function (Beck et al. 2009). My study illustrates the important role oyster reefs play in supporting fish production, in particular the juvenile stage of an important fishery species, and thus the importance of including oyster reef habitat in ecosystem-based management strategies. 


\section{Acknowledgements}

This study was funded by the Loxahatchee River District, National Science Foundation Graduate Research Fellowship \#2007050021, and Florida International University. This work was permitted by the Florida Fish and Wildlife Service, and methods followed the protocol approved by FIU IACUC \# 09-009. I thank Christina Acevedo, Albrey

Arrington, Kevin Bernhart, Joseph Brooker, Thomas Browning, Zack Jud, Evan McLean, Carlos Villegas, and Karissa Wasko for help with field work. Comments from Maureen Donnelly and Joel Fodrie helped improve the manuscript. 
Table 5.1. Isotope values and sample size for oyster reef fauna. Taxa are ordered by increasing $\delta^{15} \mathrm{~N}$ values, with the two focal consumers listed at the bottom. If more than one measurement was made for a given taxon, the mean delta-value (standard deviation) is reported.

\section{Taxa}

\begin{tabular}{|c|c|c|c|c|}
\hline Common Name & Scientific name & $\delta^{13} \mathrm{C}$ & $\delta^{15} \mathbf{N}$ & $\mathbf{N}$ \\
\hline Periwinkle & Littorina sp. & $-24.4(1.1)$ & $2.3(2.0)$ & 5 \\
\hline $\begin{array}{l}\text { Green mangrove } \\
\text { tree crab }\end{array}$ & Aratus pisonii & $-23.6(0.73)$ & $5.6(0.84)$ & 7 \\
\hline Fiddler crab & Uca sp. & $-21.1(0.74)$ & $6.1(1.2)$ & 3 \\
\hline Ribbed Mussel & Guekensia demissa & $-26.7(0.20)$ & $6.9(0.27)$ & 4 \\
\hline $\begin{array}{l}\text { Green porcelain } \\
\text { crab }\end{array}$ & Petrolisthes armatus & $-23.6(0.73)$ & $7.1(0.19)$ & 6 \\
\hline Shore crab & $\begin{array}{l}\text { Pachygraspus } \\
\text { transversus }\end{array}$ & $-21.2(0.61)$ & $7.2(0.03)$ & 3 \\
\hline Juvenile mud crabs & Xanthidae & $-20.3(1.0)$ & $7.2(0.31)$ & 8 \\
\hline $\begin{array}{l}\text { Black-fingered mud } \\
\text { crab }\end{array}$ & Eurypanopeus sp. & $-21.2(0.74)$ & $7.8(0.37)$ & 10 \\
\hline Eastern oyster & Crassostrea virginica & $-25.8(1.2)$ & $8.0(0.30)$ & 4 \\
\hline White mullet & Mugil curema & $-13.3(1.4)$ & $8.6(1.0)$ & 3 \\
\hline $\begin{array}{l}\text { Black-fingered mud } \\
\text { crab }\end{array}$ & Panopeus sp. & $-22.2(1.6)$ & $8.9(0.66)$ & 16 \\
\hline Barnacle & Balanus sp. & $-22.3(1.2)$ & $9.1(0.46)$ & 2 \\
\hline Snapping shrimp & Alpheus sp. & $-22.9(0.79)$ & $9.2(0.40)$ & 10 \\
\hline Striped mullet & Mugil cephalus & $-13.5(1.8)$ & $9.6(1.2)$ & 2 \\
\hline Pinfish & Lagodon rhombiodes & $-21.8(0.23)$ & $10.9(0.29)$ & 2 \\
\hline Other Goby & Gobiosoma sp. & $-24.6(0.32)$ & $11.0(0.68)$ & 3 \\
\hline Checkered puffer & $\begin{array}{l}\text { Sphoeroides } \\
\text { testudineus }\end{array}$ & $-24.1(0.87)$ & $11.2(0.25)$ & 34 \\
\hline
\end{tabular}




\begin{tabular}{llccc} 
Sheepshead & $\begin{array}{l}\text { Archosargus } \\
\text { probatocephalus }\end{array}$ & $-21.0(3.6)$ & $11.3(0.43)$ & 2 \\
Frillfin goby & Bathygobius soporator & $-23.4(0.96)$ & $11.4(0.40)$ & 10 \\
Mojarra & Eucinostomus sp. & $-22.9(1.1)$ & $11.6(0.69)$ & 10 \\
Mojarra & Diapterus spp. & $-22.0(2.0)$ & $11.7(0.51)$ & 4 \\
Schoolmaster & Lutjanus apodus & -20.5 & 11.9 & 1 \\
Sailor's choice & Haemulon parra & -20.5 & 11.9 & 1 \\
Highfin blenny & $\begin{array}{l}\text { Lupinoblennius } \\
\text { nicholosi }\end{array}$ & -23.4 & 12.6 & 1 \\
Jack & $\begin{array}{l}\text { Carangidae } \\
\text { Lutjanus jocu }\end{array}$ & $-20.3(0.79)$ & $12.6(0.36)$ & 2 \\
Dog snapper & $\begin{array}{l}\text { Lophogobius } \\
\text { cyprinoides }\end{array}$ & $-20.7(0.07)$ & $13.3(0.30)$ & 2 \\
Crested goby & $\begin{array}{l}\text { Lutjanus griseus } \\
\text { Gray snapper }\end{array}$ & $-22.7(1.4)$ & $12.4(0.75)$ & 46 \\
\hline
\end{tabular}




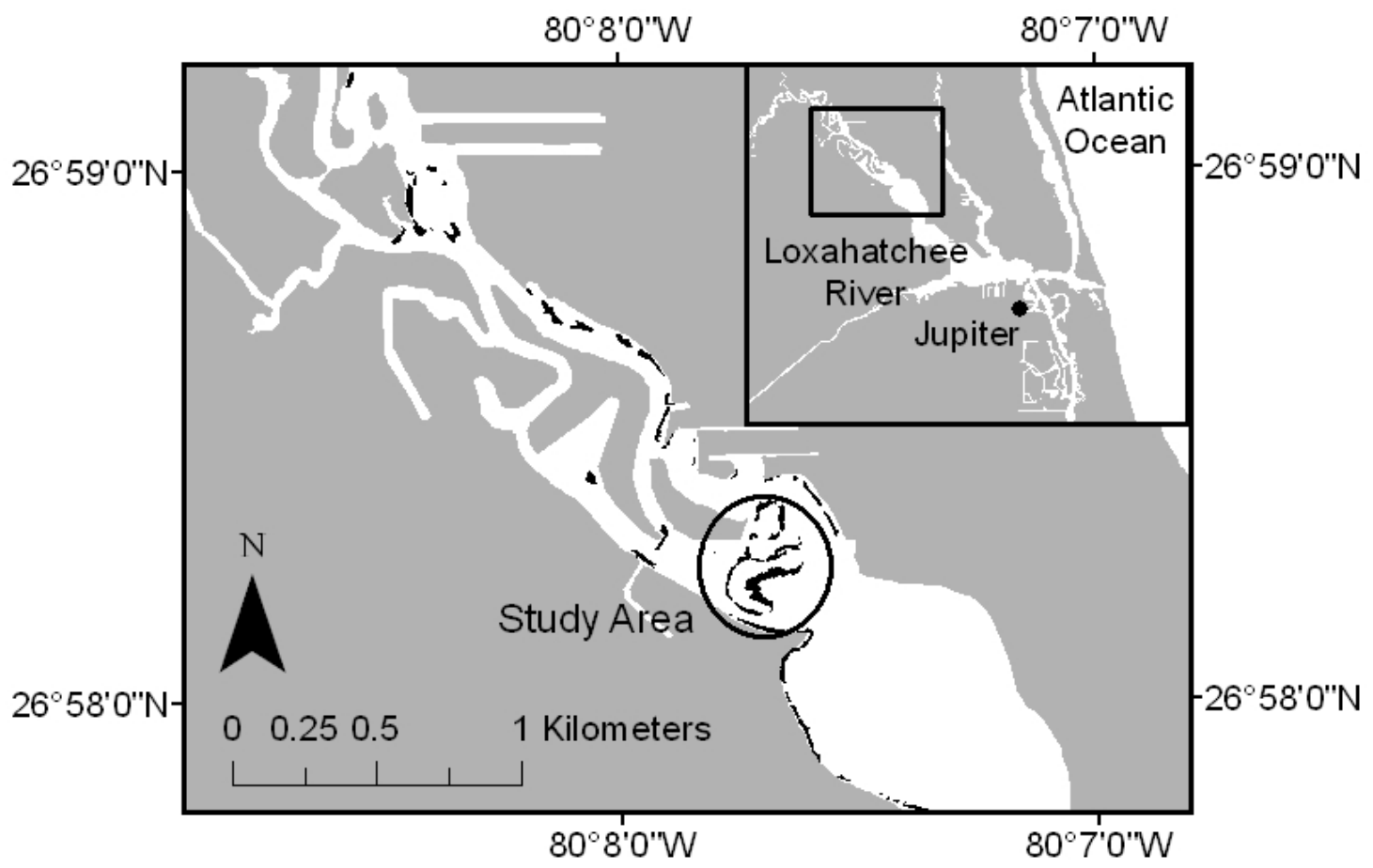

Fig. 5.1. Map of the Northwest Fork of the Loxahatchee River. Areas in black represent oyster reefs. 

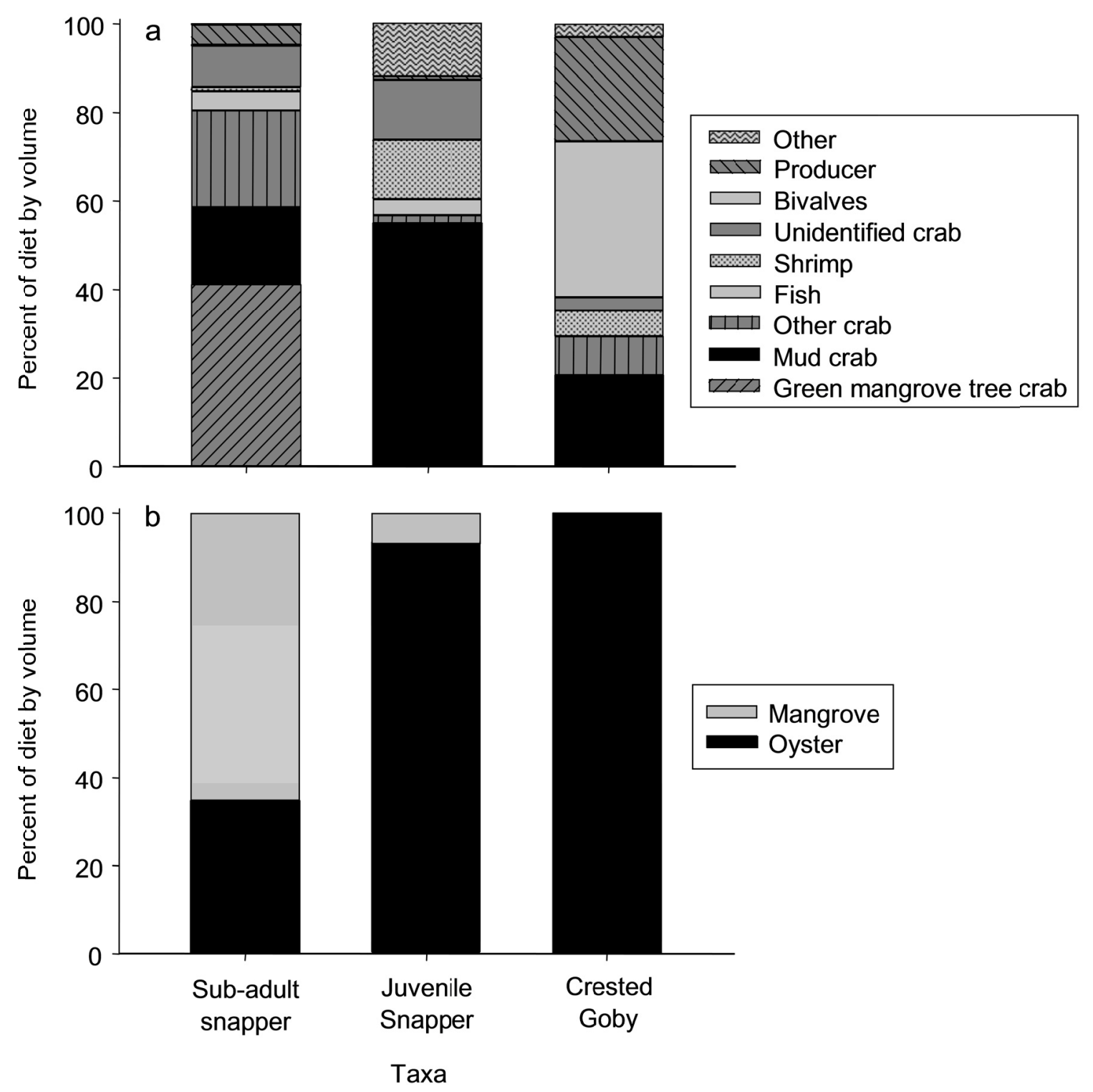

Fig. 5.2. Composition diet (by volume) of two size classes of Gray snapper (Lutjanus griseus) and Crested goby (Lophogobius cyprinoides) based on prey items (a) and habitat source of prey (b). Primary producer prey category includes vascular plants, plant detritus and algae. 


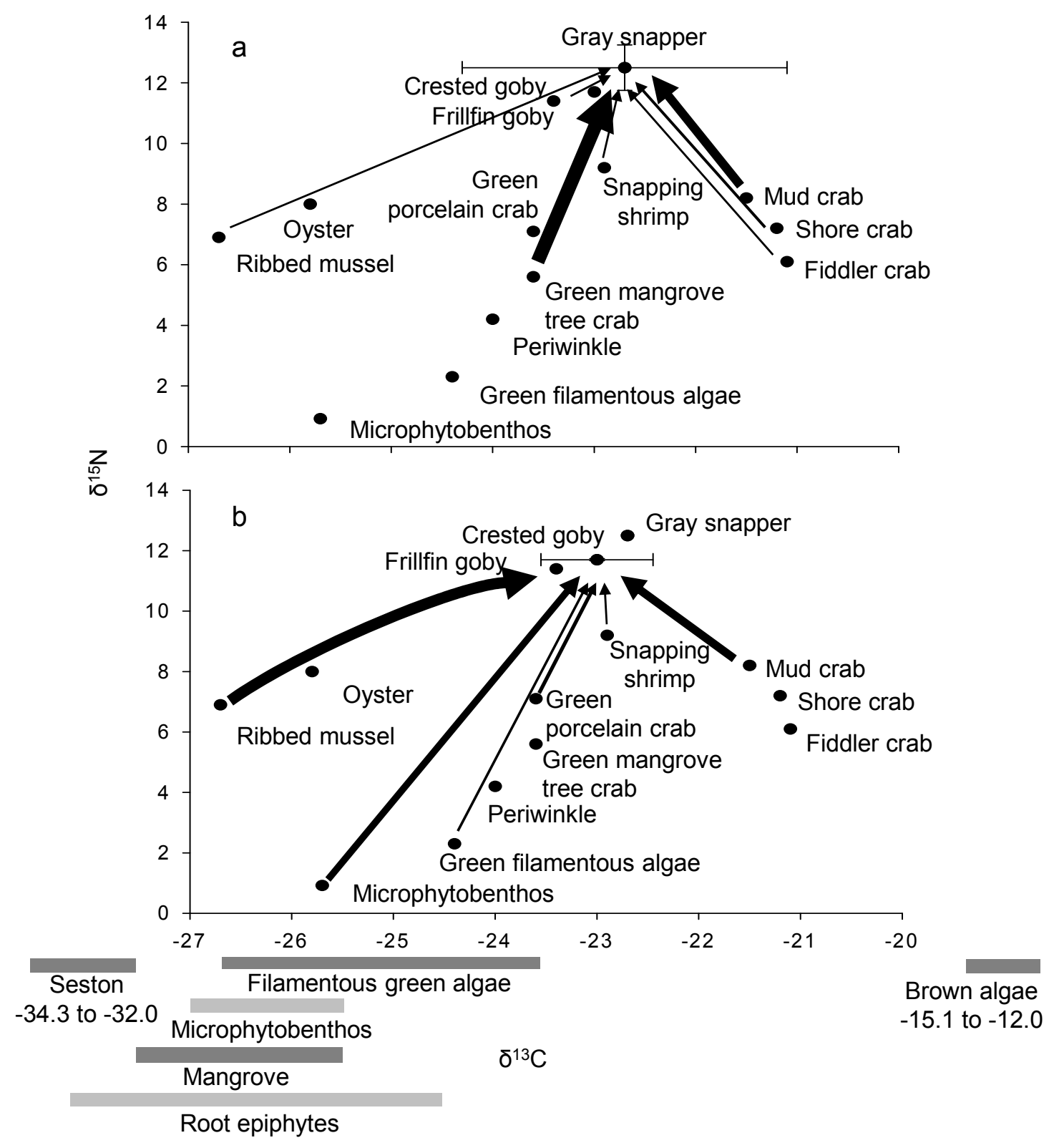

Fig. 5.3. Model food web highlighting trophic pathways leading to Gray snapper (Lutjanus griseus) (a) and Crested goby (Lophogobius cyprinoides) (b). Black dots indicate mean isotopic value for each species. Bars around Gray snapper and Crested goby dots represent standard deviation. Error bars were omitted from other species for simplicity but are given in Table 5.1. Arrows indicate a direct trophic link as determined by stomach content analysis. The width of arrows leading to a consumer reflects the proportion (by volume) of that prey item in snapper diets. The $\delta^{13} \mathrm{C}$ ranges of primary producers are represented by gray bars below the $\mathrm{x}$-axis. 


\section{Literature cited}

Beck M, Heck Jr. K, Able K, Childers D, Eggleston D, Gillanders B, Halpern BH, CG, Hoshino K, Minello T, Orth R, Sheridan P, Weinstein M (2001) The identification, conservation, and management of estuarine and marine nurseries for fish and invertebrates. Bioscience 51 (8):633-641.

Beck MW, Brumbaugh DR, Airoldi L, Carranza A, Coen LD, Crawford C, Defeo O, Edgar GJ, Hancock B, Kay M, Lenihan HS, Luckenbach MW, Toropova CL, Zhang G (2009) Shellfish reefs at risk: a global analysis of problems and solutions. The Nature Conservancy, Arlingtion VA,

Boudreaux ML, Stiner JL, Walters LJ (2006) Biodiversity of sessile and motile macrofauna on intertidal oyster reefs in Mosquito Lagoon, Florida. J Shellfish Res 25 (3):1079-1089.

Cabana G, Rasmussen JB (1996) Comparison of aquatic food chains using nitrogen isotopes. Proc Natl Acad Sci U S A 93 (20):10844-10847.

Dahlgren CP, Eggleston DB (2000) Ecological processes underlying ontogenetic habitat shifts in a coral reef fish. Ecology 81 (8):2227-2240.

Dahlgren CP, Kellison GT, Adams AJ, Gillanders BM, Kendall MS, Layman CA, Ley JA, Nagelkerken I, Serafy JE (2006) Marine nurseries and effective juvenile habitats: concepts and applications. Mar Ecol Prog Ser 312:291-295.

Dame RF, Patten BC (1981) Analysis of energy flows in an inter-tidal oyster reef. Mar Ecol Prog Ser 5 (2):115-124.

Darcy GH (1981) Food habits of the crested goby, Lophogobius cyprinoides, in 2 Dade County, Florida, waterways. Bull Mar Sci 31 (4):928-932.

Eggleston DB, Dahlgren CP, Johnson EG (2004) Fish density, diversity, and sizestructure within multiple back reef habitats of Key West National Wildlife Refuge. Bull Mar Sci 75 (2):175-204.

Faunce CH, Serafy JE (2007) Nearshore habitat use by gray snapper (Lutjanus griseus) and bluestriped grunt (Haemulon sciurus): environmental gradients and ontogenetic shifts. Bull Mar Sci 80 (3):473-495.

Faunce CH, Serafy JE (2008a) Growth and secondary production of an eventual reef fish during mangrove residency. Estuar Coast Shelf Sci 79 (1):93-100.

Faunce CH, Serafy JE (2008b) Selective use of mangrove shorelines by snappers, grunts, and great barracuda. Mar Ecol Prog Ser 356:153-162. 
Fodrie FJ, Kenworthy MD, Powers SP (2008) Unintended facilitation between marine consumers generates enhanced mortality for their shared prey. Ecology 89 (12):3268-3274.

Grabowski JH (2004) Habitat complexity disrupts predator-prey interactions but not the trophic cascade on oyster reefs. Ecology 85 (4):995-1004.

Grabowski JH, Hughes AR, Kimbro DL (2008) Habitat complexity influences cascading effects of multiple predators. Ecology 89 (12):3413-3422.

Grabowski JH, Kimbro DL (2005) Predator-avoidance behavior extends trophic cascades to refuge habitats. Ecology 86 (5):1312-1319.

Halpern BS, Gaines SD, Warner RR (2005) Habitat size, recruitment, and longevity as factors limiting population size in stage-structured species. Am Nat 165 (1):82-94.

Harding JM, Mann R (2001) Diet and habitat use by bluefish, Pomatomus saltatrix, in a Chesapeake Bay estuary. Environ Biol Fishes 60 (4):401-409.

Harding JM, Mann R (2003) Influence of habitat on diet and distribution of striped bass (Morone saxatilis) in a temperate estuary. Bull Mar Sci 72 (3):841-851.

Howard B, Arrington DA (2008) Assessment of 2007-2008 Loxahatchee River oyster mapping and recruitment (trans: Laboratory WE). Loxahatchee River District, Jupiter, Florida

Hughes AR, Grabowski JH (2006) Habitat context influences predator interference interactions and the strength of resource partitioning. Oecologia 149 (2):256-264.

Jackson JBC, Kirby MX, Berger WH, Bjorndal KA, Botsford LW, Bourque BJ, Bradbury RH, Cooke R, Erlandson J, Estes JA, Hughes TP, Kidwell S, Lange CB, Lenihan HS, Pandolfi JM, Peterson CH, Steneck RS, Tegner MJ, Warner RR (2001) Historical overfishing and the recent collapse of coastal ecosystems. Science 293 (5530):629-638.

Knott DC Introduction of the green proecelain crab, Petrolisthes armatus (Gibbes 1850) into the South Atlantic Bight. In: Pederson J (ed) Marine Bioinvasions: Proceedings of the First National Conference, Cambridge, Massachsetts, 1999. Massachusetts Institute of Technology, p 404

Layman CA (2007) What can stable isotope ratios reveal about mangroves as fish habitat? Bull Mar Sci 80 (3):513-527.

Layman CA, Arrington DA, Langerhans RB, Silliman BR (2004) Degree of fragmentation affects fish assemblage structure in Andros Island (Bahamas) estuaries. Caribb J Sci 40 (2):232-244. 
Layman CA, Post DM (2008) Can stable isotope ratios provide for community-wide measures of trophic structure? Reply. Ecology 89 (8):2358-2359.

Layman CA, Quattrochi JP, Peyer CM, Allgeier JE (2007) Niche width collapse in a resilient top predator following ecosystem fragmentation. Ecol Lett 10 (10):937944.

Layman CA, Silliman BR (2002) Preliminary survey and diet analysis of juvenile fishes of an estuarine creek on Andros Island, Bahamas. Bull Mar Sci 70 (1):199-210.

Layman CA, Winemiller KO (2004) Size-based responses of prey to piscivore exclusion in a species-rich neotropical river. Ecology 85 (5):1311-1320.

Layman CA, Winemiller KO, Arrington DA (2005) Describing the structure and function og a Neotropical river food web using stable isotope ratios, stomach contents, and functional experiments. In: Moore JC, De Ruiter PC, Wolters V (eds) Dynamic Food Webs: Multispecies Assemblages, Ecosystem Developments, and Environmental Change, vol 3. Elsevier/Acedemic Press, San Diego, USA, pp $395-406$.

Lenihan HS, Peterson CH, Byers JE, Grabowski JH, Thayer GW, Colby DR (2001) Cascading of habitat degradation: Oyster reefs invaded by refugee fishes escaping stress. Ecol Appl 11 (3):764-782.

Mathur D (1977) Food habits and competitive relationships of the bandfin shiner in Halawakee Creek, Alabama. Am Midl Nat 97 (1):89-100.

O'Connor NE, Grabowski JH, Ladwig LM, Bruno JF (2008) Simulated predator extinctions: Predator identity affects survival and recruitment of oysters. Ecology 89 (2):428-438.

Odum WE, Heald EJ (1972) Trophic analyses of an estuarine mangrove community. Bull Mar Sci 22 (3):671-738.

Paine RT (1980) Food web: Linkage, interaction strength and community infrastructure. The Journal of Animal Ecology 49 (3):667-685.

Paine RT (1992) Food web analysis through field measurement of per-capita interaction strength. Nature 355 (6355):73-75.

Peterson BJ, Fry B (1987) Stable isotopes in ecosystem studies. Annu Rev Ecol Syst 18:293-320.

Peterson CH, Grabowski JH, Powers SP (2003) Estimated enhancement of fish production resulting from restoring oyster reef habitat: quantitative valuation. Mar Ecol Prog Ser 264:249-264. 
Phillips DL, Gregg JW (2003) Source partitioning using stable isotopes: coping with too many sources. Oecologia 136:261-269.

Pittman SJ, Caldow C, Hile SD, Monaco ME (2007) Using seascape types to explain the spatial patterns of fish in the mangroves of SW Puerto Rico. Mar Ecol Prog Ser 348:273-284.

Polis GA, Winemiller KO (1996) Food Webs: Integration of Patterns and Dynamics. Chapman and Hall, New York

Post DM (2002) Using stable isotopes to estimate trophic position: models, methods, and assumptions. Ecology 83 (3):703-718.

Post DM, Layman CA, Arrington DA, Takimoto G, Quattrochi J, Montana CG (2007) Getting to the fat of the matter: models, methods and assumptions for dealing with lipids in stable isotope analyses. Oecologia 152 (1):179-189.

Rodney WS, Paynter KT (2006) Comparisons of macrofaunal assemblages on restored and non-restored oyster reefs in mesohaline regions of Chesapeake Bay in Maryland. J Exp Mar Biol Ecol 335 (1):39-51.

Schoener TW (1968) The Anolis lizards of Bimini: resource paritioning in a complex fauna. Ecology (N Y) 49 (4):704-726.

Serafy JE, Faunce CH, Lorenz JJ (2003) Mangrove shoreline fishes of Biscayne Bay, Florida. Bull Mar Sci 72 (1):161-180.

Serrano X, Grosell M, Die D, Serafy J (2007) Ecophysiology of the gray snapper: salinity effects on distribution, abundance and behavior. Comparative Biochemistry and Physiology a-Molecular \& Integrative Physiology 146 (4):24.

Shervette VR, Gelwick F (2008) Seasonal and spatial variations in fish and macroinvertebrate communities of oyster and adjacent habitats in a Mississippi estuary. Estuaries and Coasts 31 (3):584-596.

Shulman MJ (1984) Resource limitation and recruitment patterns in a coral reef fish assemblage. J Exp Mar Biol Ecol 74 (1):85-109.

Shulman MJ, Ogden JC (1987) What controls tropical reef fish populations: recruitment or bethic mortality? An example in the Caribbean reef fish Haemulon flavolineatum Mar Ecol Prog Ser 39 (3):233-242.

South Florida Water Management District (2006) Restoration plan for the Northwest fork of the Loxahatchee River (trans: Division WMDCE).

Stuart V, Klumpp DW (1984) Evidence for food-resource partitioning by kelp-bed filter feeders. Mar Ecol Prog Ser 16:27-37. 
Tolley SG, Volety AK (2005) The role of oysters in habitat use of oyster reefs by resident fishes and decapod crustaceans. J Shellfish Res 24 (4):1007-1012.

Tolley SG, Volety AK, Savarese M (2005) Influence of salinity on the habitat use of oyster reefs in three southwest Florida estuaries. J Shellfish Res 24 (1):127-137.

Tolley SG, Volety AK, Savarese M, Walls LD, Linardich C, Everham EM (2006) Impacts of salinity and freshwater inflow on oyster- reef communities in Southwest Florida. Aquat Living Resour 19 (4):371-387.

Valentine-Rose L, Cherry JA, Culp JJ, Perez KE, Pollock JB, Arrington DA, Layman CA (2007a) Floral and faunal differences between fragmented and unfragmented Bahamian tidal creeks. Wetlands 27 (3):702-718.

Valentine-Rose L, Layman CA, Arrington DA, Rypel AL (2007b) Habitat fragmentation decreases fish secondary production in Bahamian tidal creeks. Bull Mar Sci 80 (3):863-877.

Vander Zanden MJ, Rasmussen JB (1999) Primary consumer delta C-13 and delta N-15 and the trophic position of aquatic consumers. Ecology 80 (4):1395-1404.

Wada E, Mizutani H, Minagawa M (1991) The use of stable isotopes for food web analysis. Crit Rev Food Sci Nutr 30 (4):361-371.

Wallace RK (1981) An assessment of diet overlap indexes. Trans Am Fish Soc 110 (1):72-76.

Werner EE, Gilliam JF (1984) The ontogenetic niche and species interactions in size structured populations. Annu Rev Ecol Syst 15:393-425.

Werner EE, Hall DJ (1988) Ontogenetic habitat shifts in bluegill: the foraging rate predation risk trade-off. Ecology 69 (5):1352-1366.

Wilson RM, Chanton J, Lewis G, Nowacek D (2009) Combining Organic Matter Source and Relative Trophic Position Determinations to Explore Trophic Structure. Estuaries and Coasts 32 (5):999-1010.

Winemiller KO, Polis GA (1996) Food webs: what can they tell us about the world? In: Polis GA, Winemiller KO (eds) Food Webs: Integration of Patterns and Processes. Chapman and Hall, New York, USA, pp 1-22

Zaret T, Rand A (1971) Competition in tropical stream fishes: support for the competitive exclusion principle. Ecology 52 (2):336-342. 
CHAPTER VI

CONCLUSION AND FUTURE DIRECTIONS 
Landscape (and seascape) ecology has been increasingly recognized as an important framework from which to view ecological systems (Turner 2005b; GroberDunsmore et al. 2009). Context dependency of various processes regulating ecological communities may often be explained by landscape setting. For example, landscape context may determine predator abundance or shelter availability, thereby influencing the relative importance of predation pressure on focal species (Irlandi et al. 1995; Hovel \& Lipcius 2002; Schmitz 2005). In this way, a landscape ecology approach may be useful in creating better predictive models of population and community dynamics. The results of my research support this assertion; seascape context may be useful in predicting the structure and function of marine communities. On the basis of my findings, I suggest that seascape context be taken into account more frequently in ecological studies to gain a more complete understanding of coastal marine systems.

In Chapter II, I found experimental evidence that seascape context alone can affect the structure of reef fish communities using model patch reefs. While there was a positive relationship between the amount of seagrass at large spatial scales and benthic fish abundance, differences were species specific. These results suggest that changes in the coverage of seagrass around patch reefs can affect the overall abundance of fishes on reefs as well as the structure of the fish community. Future work may focus on other types of landscape-scale habitat features, such as connectivity with other structured habitats like mangroves. Additionally, some of the more vagile species may be responding to the seascape at even larger spatial scales than those evaluated in this study. For example, seascape context was not a good predictor of spiny lobster (Panulirus argus) abundance on reefs, and these species may make even larger foraging migrations 
than the most common fishes on the reefs (primarily Haemulidae). More research is also needed to determine how differences in fish abundance and community structure may be related other ecosystem functions on focal patch reefs, like nutrient cycling.

Complementary research suggests that fishes may be important nutrient vectors in these systems and increased nutrient availability mediated by fish excretion may affect primary and secondary production on the reef and in surrounding seagrass habitat (Meyer \& Schultz 1985; Allgeier et al. In press; Layman et al. In press). How seascape context may mediate this interaction has not yet been explored.

Chapter III demonstrated that seascape context may have varying effects on habitat quality for one species of reef fish (White grunt, Haemulon plumierii) depending on the level at which it is viewed. Specifically, increased availability of seagrass within the seascape was positively related to White grunt abundance and secondary production, but not metrics of condition and individual growth. Had I only attempted to evaluate habitat quality based on individual-level metrics, I would have failed to detect the importance of seascape context in affecting grunt populations at higher levels of organization (i.e., population and ecosystem function levels). This finding underscores the importance of multi-faceted approaches to gain a more complete understanding of habitat value for focal species.

While I did not find a consistent pattern between mean individual condition and seascape context in this study, some interesting patterns were found. Namely, there seemed to be a negative relationship between conspecific density (once corrected for the amount of seagrass in the seascape) and mean fish condition. The patterns suggest a density-dependent response of White grunt, although this study was not designed to test 
for such a result. An ongoing study is currently examining whether seascape context may mediate the nature of density-dependent condition for White grunts. If such a relationship is found, this would provide evidence that seascape context can affect the very nature of population regulation and provide more support for the necessity to incorporate seascape context into studies on population dynamics.

A major finding of Chapters II and III was that experimental approaches to link seascape context to various aspects of grunt population ecology generally supported what was predicted from known life-history characteristics and observational studies. For example, seagrass availability at larger spatial scales (100 m radius around reefs), as opposed to small-scale patterns, was an important predictor of White grunt abundance and secondary production on artificial reefs. The finding agreed with other observational studies that suggested $100 \mathrm{~m}$ is the approximate scale at which other grunt species respond to their seascape (Kendall et al. 2003; Pittman et al. 2007a). Therefore, my work is among the first to experimentally isolate the effects of seagrass context on reef fish communities, which proved to be a useful approach to validate previously observed patterns.

Chapter IV took a more detailed approach to understand how seascape context can affect foraging trade-offs for individuals by affecting prey availability and quality. Foraging trade-offs may be one important mechanism allowing generalist species, like Gray snapper (Lutjanus griseus), to be able to use such a wide range of habitats (Layman et al. 2004; Munday 2004; Clavel et al. 2011). I found that snapper were able to effectively compensate for lower food quality or availability in some parts of their seascape, leading to similar rates of growth and condition across study sites. 
Compensatory feeding strategies such as these may be one method by which generalist species remain successful in changing or degraded seascapes.

While I found that Gray snapper were able to maintain similar measures of condition and growth through compensatory feeding in the Loxahatchee, this may not always be the case. For example, in The Bahamas, Gray snapper suffered reduced growth rates in fragmented wetlands, presumably a result of degraded foraging conditions (Layman et al. 2007; Rypel \& Layman 2008). The comparison of these two study systems suggests that compensatory feeding may not be an effective strategy if habitat degradation is severe. Additionally, other factors like competition and predation risk may affect the capacity for compensatory feeding strategies to be successful. How these factors varied across the seascape gradient studied in Chapter IV is unknown and warrants more study.

Chapter V described major energy flow pathways to two common consumers in an oyster reef food web. My study found that these consumers, Gray snapper and Crested goby (Lophogobius cyprinoides), were supported mostly by algal production, although Crested goby did consume some sestonic feeders. For these consumers, oysters (Crassostrea virginica) may be more important in providing physical habitat that a food resource. Additionally, trophic links between oyster reef and mangrove food webs through snapper foraging were found to be dependent on body size. Only sub-adult snapper fed on mangrove-associated prey items. This difference in diet may have been caused by gape limitation or release from predation risk, allowing them to venture into adjacent mangrove habitats to feed. Whatever the mechanism, consumption of mangrove 
associated prey items by larger snapper may represent an important food web subsidy for oyster reef food webs in the Loxahatchee.

While my study examined the structure of the food web from an energy flow perspective, previous work on functional relationships between oyster reef consumers found different results. Specifically, most previous studies on functional relationships have focused on the importance of predation on oysters by mud crabs (Panopues herbstii), and how higher-order predators may affect this relationship by controlling mud crab behavior and abundance (Grabowski 2004; Grabowski et al. 2008). I found that from an energy flow perspective, oyster (sestonic-based) production did not seem to be an important prey source for mud crabs. The comparison of my findings to published studies has led to ongoing collaborations to assess the spatial and temporal importance of mud crab predation on oysters from these two different food web approaches. Such work could be very important in understanding the factors controlling populations of this foundation species.

All four of my data chapters provide support for the importance of a seascape approach to understand the structure and function of coastal communities and ecosystems. Not only does this research advance our ecological understanding of these systems, it also has important implications for how we manage and conserve them. Results of Chapters II and III suggest that seascape context of reef systems should be taken into account when designing protected areas, as it has the potential to affect fish communities on focal reefs. Furthermore, changes in seagrass habitat around reefs, due to pollution or coastal development, can affect adjacent reef fish communities. Therefore, reef and seagrass habitat cannot be managed in isolation from one another. 
Chapter IV highlighted how compensatory feeding may be one way in which generalist species are able to deal with changing seascapes. However, this mechanism may be ineffective if seascape degradation is severe. Results of Chapter $\mathrm{V}$ also suggest habitat connectivity through foraging migrations, this time between oyster reefs and mangrove ecosystems. Similar to what has been found in temperate systems (Grabowski et al. 2005), my study suggests oyster reef restoration projects should consider surrounding seascape context in sub-tropical systems. All of these chapters demonstrate a high degree of connectivity between nearshore habitats in the sub-tropics. As such, spatially-explicit management approaches are our best strategy to effectively conserve coastal, marine ecosystems.

\section{Literature Cited}

Allgeier J.E., Yeager L.A. \& Layman C.A. (In press). Consumer aggregation regulates nutrient limitation regimes and primary production. Ecology.

Appeldoorn R.S., Aguilar-Perera A., Bouwmeester B.L.K., Dennis G.D., Hill R.L., Merten W., Recksiek C.W. \& Williams S.J. (2009). Movement of fishes (Grunts: Haemulidae) across the coral reef seascape: A review of scales, patterns and processes. Caribb. J. Sci., 45, 304-316.

Clavel J., Julliard R. \& Devictor V. (2011). Worldwide decline of specialist species: toward a global functional homogenization? Front. Ecol. Environ., 9, 222-228.

Grabowski J.H. (2004). Habitat complexity disrupts predator-prey interactions but not the trophic cascade on oyster reefs. Ecology, 85, 995-1004.

Grabowski J.H., Hughes A.R. \& Kimbro D.L. (2008). Habitat complexity influences cascading effects of multiple predators. Ecology, 89, 3413-3422.

Grabowski J.H., Hughes A.R., Kimbro D.L. \& Dolan M.A. (2005). How habitat setting influences restored oyster reef communities. Ecology, 86, 1926-1935.

Grober-Dunsmore R., Pittman S.J., Caldow C., Kendall M.S. \& Frazer T.K. (2009). A landscape ecology approach for the study of ecological connectivity across 
tropical marine seascapes. In: Ecological Connectivity among Tropical Coastal Ecosystems (ed. Nagelkerken I). Springer, pp. 493-530.

Hovel K.A. \& Lipcius R.N. (2002). Effects of seagrass habitat fragmentation on juvenile blue crab survival and abundance. J. Exp. Mar. Biol. Ecol., 271, 75-98.

Irlandi E.A., Ambrose W.G. \& Orlando B.A. (1995). Landscape Ecology and the MarineEnvironment - How Spatial Configuration of Seagrass Habitat Influences Growth and Survival of the Bay Scallop. Oikos, 72, 307-313.

Kendall M.S., Christensen J.D. \& Hillis-Starr Z. (2003). Multi-scale data used to analyze the spatial distribution of French grunts, Haemulon flavolineatum, relative to hard and soft bottom in a benthic landscape. Environ. Biol. Fishes, 66, 19-26.

Layman C.A., Allgeier J.E., Yeager L.A. \& Stoner E.W. (In press). Thresholds of ecosystem response to nutrient enrichment by aggregating fishes. Ecology.

Layman C.A., Arrington D.A., Langerhans R.B. \& Silliman B.R. (2004). Degree of fragmentation affects fish assemblage structure in Andros Island (Bahamas) estuaries. Caribb. J. Sci., 40, 232-244.

Layman C.A., Quattrochi J.P., Peyer C.M. \& Allgeier J.E. (2007). Niche width collapse in a resilient top predator following ecosystem fragmentation. Ecol. Lett., 10, 937944.

Meyer J.L. \& Schultz E.T. (1985). Migrating Haemulid Fishes as a Source of Nutrients and Organic-Matter on Coral Reefs. Limnol. Oceanogr., 30, 146-156.

Munday P.L. (2004). Habitat loss, resource specialization, and extinction on coral reefs. Global Change Biology, 10, 1642-1647.

Ogden J.C. \& Ehrlich P.R. (1977). Behavior of Heterotypic Resting Schools of Juvenile Grunts (Pomadasyidae). Mar. Biol., 42, 273-280.

Pittman S.J., Caldow C., Hile S.D. \& Monaco M.E. (2007). Explaining patterns of abundance for fish using mangroves: A multi-scale seascape approach. Bull. Mar. Sci., 80, 930-931.

Rypel A.L. \& Layman C.A. (2008). Degree of aquatic ecosystem fragmentation predicts population characteristics of gray snapper (Lutjanus griseus) in Caribbean tidal creeks. Can. J. Fish. Aquat. Sci., 65, 335-339.

Schmitz O.J. (2005). Scaling from plot experiments to landscapes: studying grasshoppers to inform forest ecosystem management. Oecologia, 145, 225-234.

Turner M.G. (2005). Landscape ecology: What is the state of the science? Annu. Rev. Ecol. Evol. Syst., 36, 319-344. 


\section{LAUREN ANN YEAGER}

2006 Bachelor of Science, Eckerd College, St. Petersburg, FL

Majors: Marine Science (Biology Track) and Spanish, GPA 4.0

\section{PROFESSIONAL/RESEARCH EXPERIENCE}

2007-2012 Graduate Research Fellow, National Science Foundation, Florida International University

2008-2010 Presidential Fellow, Florida International University

2006-2007 Fulbright Researcher, Institute of International Education

2003-2007 Wetland Ecology Intern, U.S. Geological Survey

\section{AWARDS AND HONORS}

2012 Dissertation Year Fellowship, Florida International University

2012 FIU University Graduate School Provost Award for Outstanding Paper or Manuscript

2007 National Science Foundation Graduate Research Fellowship

2007 Presidential Fellowship, Florida International University

$2006 \quad$ Fulbright Scholar

\section{PUBLICATIONS}

Layman, CA. Allgeier, JE, Yeager, LA, Stoner, EW. In press. Thresholds of ecosystem response to nutrient enrichment from fish aggregations. Ecology.

Allgeier, JE, Yeager, LA, and Layman, CA. In press. Consumer regulation of nutrient limitation regimes and primary production. Ecology.

Yeager, LA, Acevedo, CL, and Layman, CA. 2012. Effects of seascape context on condition, abundance, and secondary production of a coral reef fish, Haemulon plumierii. Marine Ecology Progress Series 462: 231-240. 
Layman, CA, Araújo, MS, Boucek, R, Harrison, E, Jud, ZR, Matich, P, HammerschlagPeyer, CM, Rosenblatt, A, Vaudo, J, Yeager, LA, Post, DM, and Bearhop, S. 2012. Applying stable isotopes to examine food web structure: an overview of analytical tools. Biological Reviews 87(3): 545-562.

Hammerschlag-Peyer, CM, Yeager, LA, Araujo, MS, and Layman, CA. 2011. A hypothesis-testing framework for studies investigating ontogenetic niche shifts using stable isotope ratios. PLoS ONE 6(11): e27104.

Yeager, LA, Layman, CA, and Allgeier, JE. 2011. Effects of habitat heterogeneity at multiple spatial scales on fish community assembly. Oecologia 167:157-168.

Stoner, EW, Layman, CA, Yeager, LA, Hassett, HM. 2011. Effects of anthropogenic disturbance on the abundance and size of epibenthic jellyfish Cassiopea spp. Marine Pollution Bulletin 62: 1109-1114.

Yeager, LA and Layman, CA. 2011. Energy flow to two abundant consumers in a subtropical oyster reeffood web. Aquatic Ecology 45:267-277.

Layman, CA, Allgeier, JE, Rosemond, AD, Dahlgren, CP, and Yeager, LA. 2011. Marine Fisheries Declines Viewed Upside Down: Human Impacts on Consumer-Driven Nutrient Recycling. Ecological Applications 21:343-349.

Yeager, LA and Arias-Gonzalez, JE. 2008. Preliminary survey of fish community composition in seagrass habitat in two back-reef lagoons of the southern Mexican Caribbean. Gulf and Caribbean Research 20: 41-47.

Yeager, LA, JM Krebs, AB Brame, CC McIvor. 2007. Comparison of juvenile blue crab abundances in three mangrove habitat types in Tampa Bay, Florida USA. Bulletin of Marine Science 83: 555-565.

Yeager, LA. 2006. Habitat utilization by reef fishes of three shallow-water biotopes in Manzanillo, Costa Rica. B.S. Senior Research Thesis, Eckerd College. 